Türkiye Jeoloji Bülteni
Geological Bulletin of Turkey
$61(2018) 91-130$
doi:10.25288/tjb.358187

\title{
Anamur (Alanya Masifi, Mersin) Bölgesinde Yer Alan Prekambriyen Yaşlı Kayaçların Çok Evreli P-T-t Evrimi
}

Multi-Stage P-T-t Evolution of Precambrian Aged Rocks in Anamur (Alanya Massif, Mersin) Region

\section{Mete Çetinkaplan (D)}

\author{
Dokuz Eylül Üniversitesi, Jeoloji Mühendisliği Bölümü, 35160 İzmir
}

Geliş/Received : 23.06.2017 • Düzeltilmiş Metin Geliş/Revised Manuscript Received : 22.11.2017 • Kabul/Accepted : 01.12.2017• Bask1/Printed : 01.01 .2018 Araştırma Makalesi/Research Article Türkije Jeol. Bül. / Geol. Bull. Turkey

Öz: Alanya Masifi’nin doğu kesimde yer alan Anamur bölgesi yüksek sıcaklık metamorfizması ile tanımlanmaktadır. Bölgede bazik ve asidik meta-magmatikler tarafından kesilen, üst amfibolit fasiyesi koşullarında başkalaşıma uğramış metakırıntılılar (Sarıăaç birimi) paraotokton konumlu temeli oluşturmaktadır. Barrov türü orta basınç metamorfizmasının yeşilşist fasiyesi koşullarında başkalaşıma uğramış Kapıdağ napı, Sarıăaç birimini sünümlü koşullarda gelişmiş tektonik bir dokanakla üzerlemektedir. Düzenli ve kalın bir istif oluşturan Kapıdağ napı tabanda dolomit, mermer, muskovit- kuvars şist ve klorit şist ardalanmasından oluşan, olasılı İnfrakambriyen yaşlı topluluk ile başlamaktadır. Bu birim üzerine, Toros birliklerinin Kambro-ordovisiyen yaşlı Hüdai, Çaltepe ve Seydişehir formasyonlarından türeme, kuvarsit, meta-karbonat ve şistlerden yapılı düşük dereceli metamorfikler gelmektedir. Tüm bu metamorfik birimler Geç Eosen-Oligosen yaşlı Anamur Formasyonu'na ait çakıltaşları ile uyumsuz olarak örtülmekte ve Hadim napı tarafından tektonik olarak üzerlenmektedir.

Sarıağaç birimini oluşturan yüksek dereceli şistlerin metamorfizma (M1) koşulları $7.7 \pm 0.7$ kbar ve $670 \pm 20^{\circ} \mathrm{C}$ olarak belirlenmiş̧ir. Bu yüksek dereceli topluluk $5.1 \pm 0.3 \mathrm{kbar}$ ve $480 \pm 40^{\circ} \mathrm{C}$ koşullarında (M2) retrograd metamorfizmaya uğramıştır. Üzerleyen M2 metamorfizmasının yaşı beyaz mikalardan elde edilen $\mathrm{Ar} / \mathrm{Ar}$ yaş belirlemesine göre 75 - 73 My (Kampaniyen) olarak bulunmuştur. M1 metamorfizmasının yaşı doğrudan belirlenememiştir. Fakat M1 metamorfizması ürünü bölgesel foliyasyonu kesen meta-aplitlerden elde edilen ve ilksel asidik magmatiklerin kristalizasyon yaşı olarak yorumlanan 550.2 \pm 8.2 My U/Pb zirkon yaşları söz konusu temeli etkileyen bu metamorfizmanın olasılıkla Prekambriyen yaşlı olduğunu göstermektedir. Bu veri ayrıca temeli oluşturan metakırıntılıların ilksel kayalarının Prekambriyen yaşlı olduğunu ortaya koymaktadır. Alanya Masifinnin paleocoğrafik konumu ve jeokronolojik veriler göz önüne alındığında, M1 metamorfizması Gondwana'nın Geç Neoproterozoyik'teki bütünleşme süreci ile ilişkilendirilebilmektedir. Bu yüksek dereceli temel Neotetis okyanusunun güney kolunun kapanması ile ilişkili olarak Geç Kretase'de yeşilşist fasiyesi koşullarında gelişen M2 metamorfizması tarafindan üzerlenmiştir.

Anahtar Kelimeler: Anamur, Gondwana, metamorfizma, sillimanit

Abstract: The Anamur region in the eastern part of the Alanya Massif is defined by high temperature metamorphism. Metamorphic rocks (Sarıağaç unit), under the conditions of the upper amphibolite facies which are interrupted by basic and acidic meta-magmatics in the region, constitute the para-autochtonous basis. Kapldağ nappe, has undergone metamorphism the Barrow-type medium-pressure metamorphism in the greenschist facies is overlain by the tectonic contact of the Sarıağaç unit with the ductile conditions. The Kapıdağ nappe, which forms a regular and thick sequence, begins with a probable infra-cambrian aged assemblage in the base consisting of dolomite, marble, muscovite-quartz schist and chlorite schist alternation. This assemblage is overlain by low-grade metamorphics of Tauride units consist of quartzite, meta-carbonate and schists derived from Hüdai, Çaltepe and Seydişehir formations in Cambro-Ordovician aged. All these metamorphic units are unconformably overlain by conglomerates belonging to Late Eocene-Oligocene Anamur Formation and then Hadim nappe thrusted over to all units. 
The metamorphism (M1) conditions of the high grade schists of the Sarlağaç unit are $7.7 \pm 0.7 \mathrm{kbar}$ and $670 \pm 20^{\circ} \mathrm{C}$. This high-grade assemblage underwent retrogration $5.1 \pm 0.3 \mathrm{kbar}$ and $480 \pm 40^{\circ} \mathrm{C}$ (M2) in conditions. The dating of this metamorphism is 75-73 Ma (Campanian) based on Ar/Ar white mica aging. The age of M1 metamorphism could not be directly determined. Zircon ages of 550.2 $18.2 \mathrm{Ma}(\mathrm{U} / \mathrm{Pb})$, which is interpreted as the age of crystallization of the primary acidic magmatics and the meta-aplites intersecting the regional foliation which is product of MI metamorphism suggest that this metamorphism affecting the basement is probably Precambrian aged.

This data also reveals that the primary metaclastic rocks of the basement-forming metamorphic rocks are Precambrian aged. Given the paleogeographic location of the Alanya massif and geochronological data, the M1 metamorphism may be associated with the integration process of Gondwana's Late Neoproterozoic. This high-grade basement was overprinted by the M2 metamorphism developed from the greenschist facies in the Late Cretaceous, associated with the closure of the southern part of the Neotethys ocean.

Keywords: Anamur, Gondwana, metamorphism, sillimanite

\section{GíRiş}

Türkiye Neotetis okyanusu kollarının kapanmasıyla ilişkili olarak yaklaşık doğu - batı yönlü sutur zonlarıyla ayrılmış çok sayıda kıtasal parçanın birbirine kaynamasıyla oluşmuştur. Bu tektonik mozaik Gondvana'nın kuzey kenarı boyunca gelişen riftleşme ve okyanuslaşma süreçlerinin bir sonucu olarak gelişmiştir. $\mathrm{Bu}$ tektonik çatı içerisinde, İzmir - Ankara - Erzincan sutur zonu, Geç Kretase - Eosen zaman aralığında Neotetis okyanusunun kuzey kolunun kapanması ve Sakarya Zonu ile Anatolid-Torid Platformu'nun çarpışmasını tanımlamaktadır (Candan ve diğ. 2005; Okay ve Tüysüz 1999; Okay ve diğ. 2001; Pourteau ve diğ. 2013; Rolland ve diğ. 2009). Bitlis - Zagros sutur zonu ise Miyosen'de Anatolid - Toridler'le Arap levhasının çarpışması ve güney Neotetis okyanusunun kapanması ile ilişkilendirilmektedir (Parlak ve diğ. 2009; Şengör ve Y1lmaz 1981; Y1lmaz 1993). Toridler ve onların metamorfik eşlenikleri olan Anatolidler Gondvana kökenli tektonik ünitelerdir. Ortak Paleozoyik Erken Triyas stratigrafisine sahip olan Anatolid ve Toridler Triyas'da (Göncüoğlu ve diğ. 2003; Okay et al. 1996, 2006) veya Jura'da (Şengör ve diğ. 1980, 1985) Neotetis okyanusunun kuzey ve güney kollarının açılmasıyla izole bir blok olarak Gondwana' dan koparılmıştır. İlksel birikim ortamı ve sedimanter fasiyes karekteristiklerine dayalı olarak, Anatolid - Torid bloğu güneyden kuzeye doğru Alanya, Antalya, Geyik Dağı, Aladağ ve
Bozkır olmak üzere doğru çok sayıda birliğe ayrılmaktadır. Bu yapı içerisinde Alanya Masifi, Geç Kretase'de Neotetis okyanusunun kuzey yönlü yitimi (Özgül 1976) ve bunla ilişkili çok evreli metamorfizma sonucu Alanya birliğinden türemiş olduğu kabul edilir. Alanya Masifi'nde eklojit - mavişist fasiyesine ait kayaçların varlığı ilk kez Okay ve Özgül (1984) ve Okay (1989) tarafindan ortaya konmuştur. Bu kayaçlar, Barrov tipi orta basınç / düşük sıcaklık metamorfizmasına uğramış nap paketi içerisinde bir tektonik dilim olarak bulunmaktadır (Okay 1989; Çetinkaplan ve diğ., 2016). Bunların yanı sıra Masif'in kuzey batı ucunda yüzeyleyen mavişist bloklu melanj Çetinkaplan ve diğ., (2016) tarafından Geç Kretase yaşlı yitim ile ilişkilendirilmektedir.

$\mathrm{Bu}$ genel yapıya karşın Masif'in güneydoğusunda, Anamur bölgesinde bulunan metamorfikler yüksek sıcaklık metamorfizmasına ilişkin veriler sunmaktadır (Bozkaya 2001; Bozkaya ve Yalçın 2004; Işık ve Tekeli,1995). $\mathrm{Bu}$ bölgedeki metamorfikler içerisinde stavrolit ve disten gibi minerallerin varlığı, söz konusu metamorfik kayaçların Barrov tipi üst amfibolit fasiyesi koşullarında metamorfizmaya uğradığını göstermektedir (Bozkaya 2001; Bozkaya ve Yalçın 2004; Işık ve Tekeli, 1995). Alanya Masifi'nin genelinde metamorfizma derecesinin Barrov türü düşük yeşil şist fasiyesi koşullarında olması (Bozkaya 1999; Bozkaya 2001; Bozkaya ve Yalçın 2004; Çetinkaplan ve diğ. 2016; Okay ve Özgül, 
1984; Okay 1989; Ulu 1989) Anamur bölgesindeki yüksek dereceli metamorfiklerin Alanya Masifi ile olan ilişkisini tartışılır hale getirmektedir. Bu çalışmada söz konusu bölgede ayrıntılı harita alımı gerçekleştirilmiş ve petrolojik / jeokronolojik çalışmalarla yüksek dereceli kayaçların protolit yaşları ve metamorfik evrimlerine yönelik ayrıntılı veri elde edilmiştir. Söz konusu metamorfiklerin Neotetis okyanusunun güney kolunun Geç Kretase evrimi içerisindeki yerlerinin belirlenmesi ve Alanya Masifi ile olan olasılı korelasyonlan bu çalışmanın ana hedeflerini oluşturmaktadır.

\section{TEKTONO-STRATIGRAFI}

Alanya Masifi'nin güney doğu kesiminde, Anamur'un kuzeyinde yer alan çalışma alanı Paleosen öncesi ve Eosen sonrası sıkışma tektoniği ürünü bindirme fayları ile tanımlanan tipik bir nap yığını yapısı sunmaktadır. Ana üniteler alttan üste doğru; i)Alanya Masifi'ne ait metamorfikler (Işık ve Tekeli 1995), onları uyumsuz olarak üzerleyen

ii) Paleosen - Eosen yaşlı Anamur Formasyonu (Ulu 1989) ve bölgeye Geç Eosen - Oligosen (Turan ve diğ. 2007) sürecinde yerleşmiş iii) Toroslar'ın Aladă̆ Birliğine ait Hadim Nap1 olarak verilebilir (Şekil 1a-b).

Alanya Masifi metamorfikleri Alanya güney doğusunda Özgül (1984) ve Okay ve Özgül, (1984) tarafından alttan üste doğru Mahmutlar, Sugözü ve Yumrudağ napları olarak tanımlanmıştır.
Mahmutlar ve Yumrudağ naplarında yapılan ayrıntılı çalışmalarda bu napların farklı dilimlerden oluştuğu görülmüş ve sözkonusu naplar Özgül (1984) ve Okay ve Özgül, (1984)'e mümkün olduğunca sadık kalınarak Çetinkaplan ve diğ., (2016) tarafindan Mahmutlar nap topluluğu ve Yumrudağ nap topluluğu olarak tanımlanmıştır. Mahmutlar nap topluluğu Gökketir nap1 ve üzerleyen Kargıcak napından yapılıdır. Yumrudağ nap topluluğu ise kendi içinde Kapıdağ napı ve Kiraz Dağı napı olmak üzere iki tektonik dilim içermektedir. Anamur bölgesindeki birim ve nap adlamalarında ana hatlarıyla Özgül (1984) ve Okay ve Özgül, (1984)'den gelen ve Çetinkaplan ve diğ., (2016) tarafindan detaylandırılan adlamalara sadık kalınmıştır.

$\mathrm{Bu}$ kapsamda Anamur kuzeyindeki Alanya Masifi metamorfikleri altta Sarıăaç Birimi ve bunu tektonik bir dokanakla üzerleyen Yumrudağ nap topluluğu'nun Kapıdağ napından yapılıdır (Şekil 1b). Sarıăaç Birimi bölgede paraotokton konumdadır. Alt dokanağı gözlenmeyen bu birim üst amfibolit fasiyesi koşullarında başkalaşıma uğramış yüksek dereceli şistlerle tanımlanmaktadır. Prekambriyen yaşlı psamitikpelitik kırıntılılardan türeme bu kayalar $550 \mathrm{My}$ yaşl1, genelde aplit-pegmatit bileşimli asidik ve daha ender olarak bazik magmatik damar kayaları tarafindan kesilmektedir. Alanya Masifinde bir eşleniği olmayan bu birim Sarıăgaç birimi olarak adlanmıştır. 


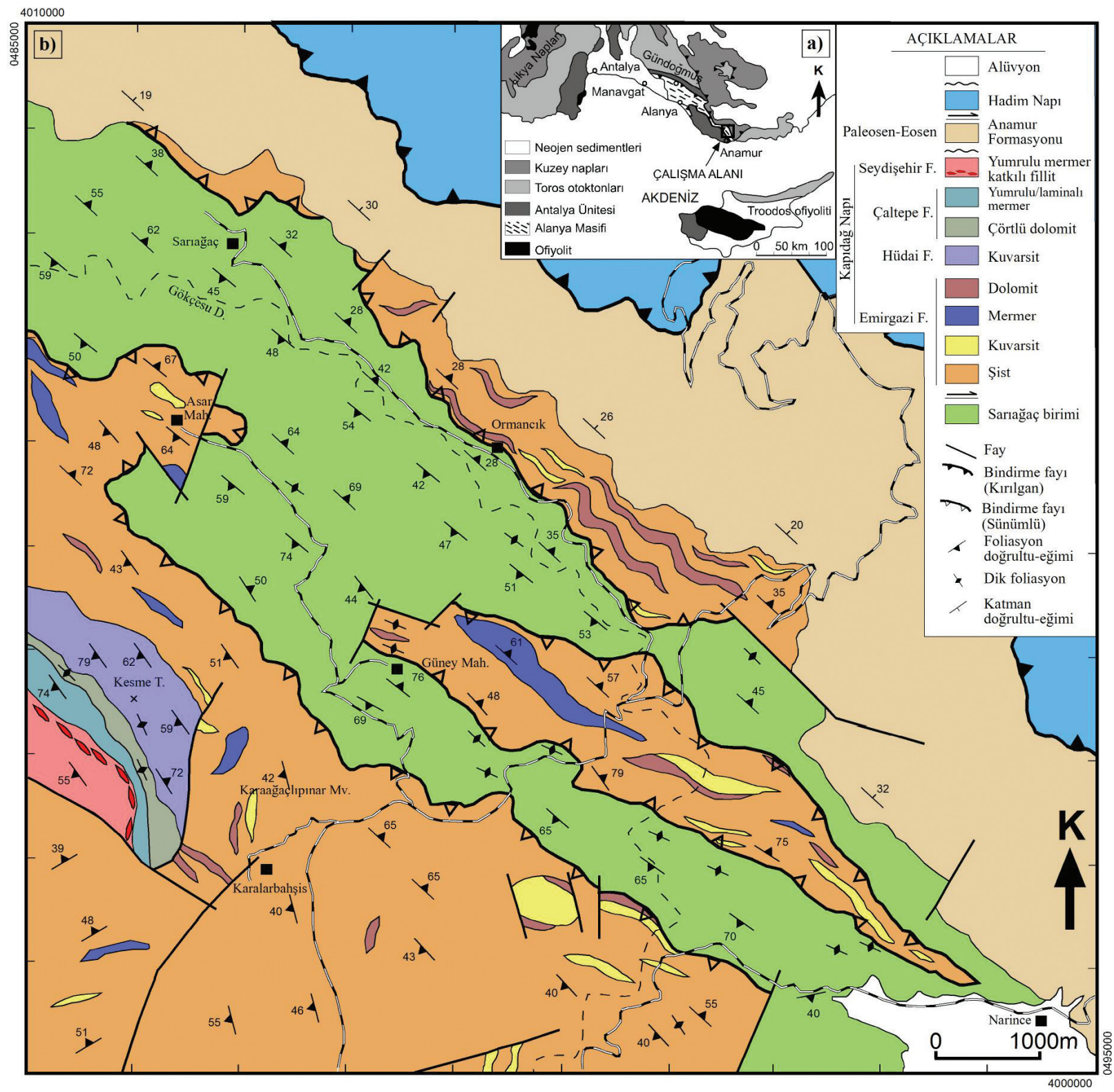

Şekil 1. a) Orta Toroslardaki ana tektonik üniteleri gösteren genelleştirilmiş tektonik harita üzerinde çalışma alanının konumu (Okay 1986 dan değiştirerek), b) Anamur kuzeyinde yer alan çalışma alanına ait jeoloji haritası.

Figure 1. a) Generalized tectonic map showing the main tectonic units of the Middle Tauride Mountains (after Okay 1986) and location of the study area, b) geological map of the study area located in the north of Anamur. 

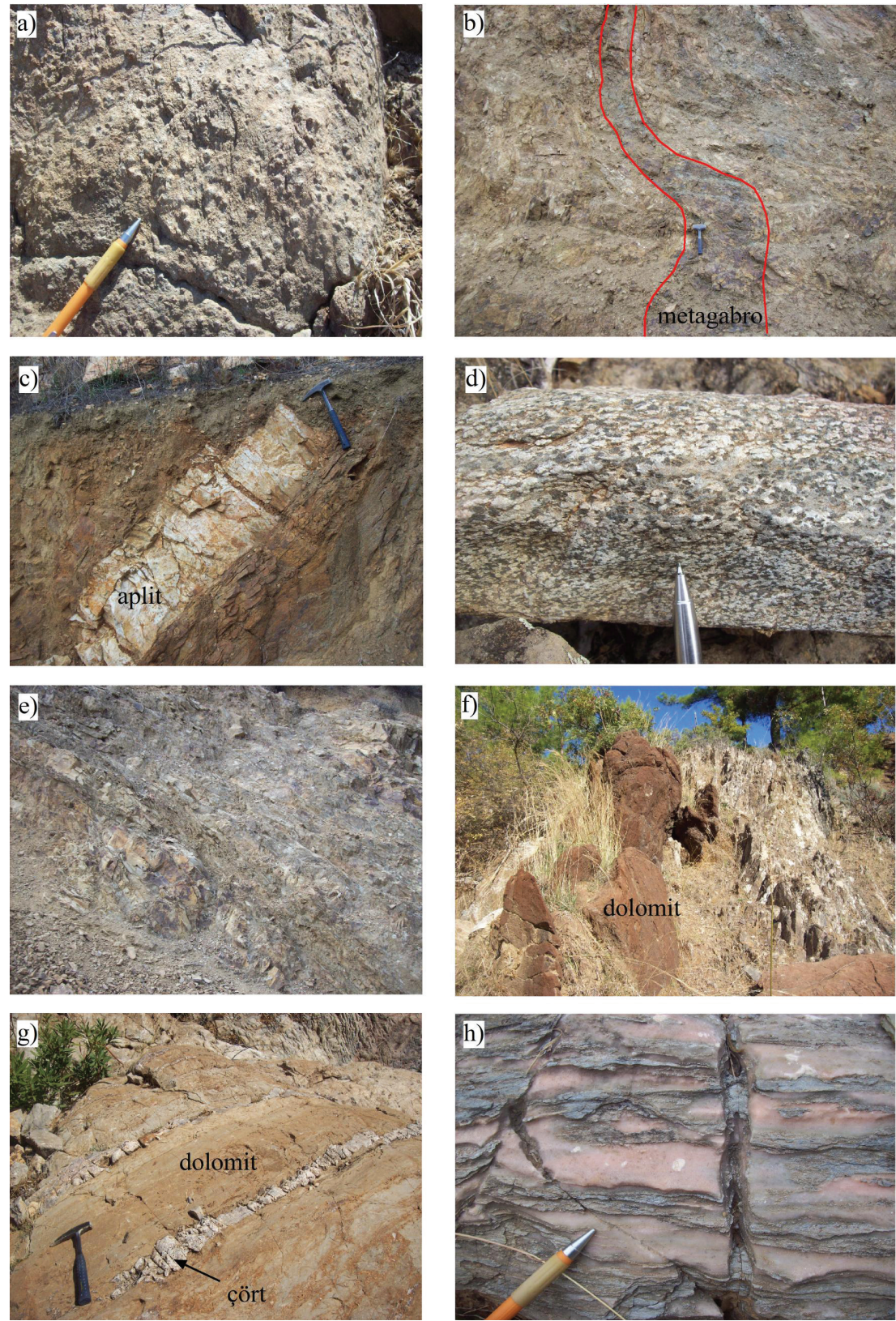

Şekil 2. a) Sarıăgaç birimi içerisinde bulunan şistlerde yaygın olarak gözlenen granat porfiroblastları (Akine köyü güneyi), Prekambriyen yaşlı yüksek dereceli şistler içerisine yerleşmiş (b) gabroik, (c) aplit ve (d) diyoritik damar kayaçları, e) Emirgazi Formasyonuna ait açık yeşil - kirli sarı renkli şistler, f) Emirgazi Formasyonu içerisinde gözlenen kahverengi ayrışma renkli dolomit, g) Çaltepe Formasyonunun tabanında yer alan çörtlü dolomitler, h) Çaltepe Formasyonunu üst kesimlerinde ve Seydişehir Formasyonun alt kesimlerinde gözlenen kırmızı yumrulu mermerler.

Figure 2. a) Garnet porfiroblasts observed in schists of Sarlağaç Unit (south of Akine village), Precambrian-aged high-grade schists intruded by (b) gabbroic, (c) aplite and (d) diorite vein rocks, e) the light green - dirty yellow coloured schists belonging to Emirgazi formation, f) the brown-coloured weathering dolomite in Emirgazi formation, $g$ ) the cherty dolomites at the base of Çaltepe formation, $h$ ) red nodular marbles observed in the upper part of Çaltepe Formation and the lower part of the Seydişehir Formation. 
Kapıdağ nap1 düzenli ve kesiksiz bir ilksel tortul istifden türeme, kendi içerisinde ekaylanmalar gösteren, alt yeşilşist fasiyesi koşullarındaki düşük dereceli metamorfik kayaçlardan yapılıdır. Birimin Toroslar'a ait Geyikdağ1 Birliği'nin İnfrakambriyen- Erken Paleozoyik istifini içeriyor olması nedeniyle formasyon adlamalarında orijinal adlamalara sadık kalınmıştır (Özgül 1976). Birim tabanda, olasıl1 İnfrakambriyen yaşl1, klorit-albit şist, kahverengi dolomit, mermer ve sarı muskovitkuvars şist ardalanmasından yapılı Emirgazi Formasyonu (Kozlu 1990; Özgül ve Kozlu 1992) ile başlamaktadır. Bu ardalanmalı, seri yaklaşık 100 metre kalınlığında homojen muskovit-kuvars şistlerle tanımlanan Hüdai Formasyonu (Dean ve Özgül, 1994) tarafindan üzerlenmektedir. Kuvarsarenitik kumtaşlarından dönüşme bu istif kalınlığı 180 metreye ulaşan bir mermer düzeyi ile uyumlu olarak üzerlenmektedir. Çaltepe Formasyonu (Dean ve Monod, 1970; Monod 1977) olarak adlandirılan bu karbonatlar kendi içerisinde alttan üste doğru koyu gri çörtlü dolomit, gri dolomit, laminalı beyaz mermer ve pembemsi renkli yumrulu mermerlerden oluşan düzenli bir stratigrafi sunmaktadır. Karbonat düzeyi uyumlu bir dokanakla şeyl ve silttaşından türeme kloritalbit şistlerle üzerlenmektedir. Stratigrafik konum ve ilksel kaya bileşimine dayanarak bu birim Seydişehir Formasyonu (Dean ve Monod, 1970; Monod 1977) ile eşleştirilmektedir.

Sarıăaç Birimi ve Kapıdağ napı üzerine açısal uyumsuz bir dokanakla, görünür kalınlığı 2 km'ye ulaşan, Paleosen-Eosen yaşlı (Ulu, 1989) Anamur Formasyonu gelmektedir. Taban çakıltaşı ile başlayan Anamur Formasyonu çakıltaş1, kumtaş1, çamurtaş1, silttaş1 ve kireçtaş1 düzey ve merceklerinin ardalanmasından oluşmaktadır. Çakıltaşları ve gri kireçtaşları formasyon içerisinde baskın olan litolojilerdir. Çakıltaşları, karbonat bir matriks ve gri / beyaz kireçtaşı, kumtaşı, çamurtaşı ve şist çakıllarından oluşmaktadır. Çalışma alanında istifsel olarak en üst tektonik dilimi oluşturan Hadim Napı (Aladağ Birliği, Özgül 1997) kırılgan deformasyon özellikleri gösteren, Eosen sonrası bir bindirme fayıyla Anamur Formasyonunu üzerlemektedir.

\section{JEOLOJI}

\section{Sarıăgaç Birimi}

Üst amfibolit fasiyesi koşullarında Barrov tipi metamorfizmaya uğramış olan Sarıăgaç Birimi Prekambriyen yaşl1 yüksek dereceli şistler ve onlar içerisine sokulmuş asidik - bazik meta-magmatik kayaçlardan oluşmaktadır. Birim bölgede Sarıăaç ve Narince köyleri arasında yaklaşı 10 km'lik bir hat boyunca KB-GD yönlü uzanım göstermektedir. Biyotit ve muskovit bakımından zengin, iri kristalli şistler kuvvetli foliyasyona sahip olup 3-5 mm'ye ulaşan granat porfiroblastları içermektedir (Şekil 2a). Disten, sillimanit ve stavrolit ise mikroskobik boyutlardadır. Şistler mineral içeriklerine göre sillimanit-disten-granat şist, disten- stavrolitgranat şist, disten-granat-biyotit şist, granatmuskovit şist ve granat-biyotit şist olmak üzere beş farklı bileşim sunmaktadır.

Şistler, metamorfizmaya uğramış ortaç - bazik bileşimli damar kayaları ve aplit - pegmatitler tarafindan yoğun olarak kesilmektedir (Şekil 2b-c). Ayrışma yüzeylerinde plajiyoklaz ve hornblendin kolaylıkla tanınabildiği, yeşil - koyu yeşil renklerde, iri ve orta taneli olarak gözlenen ortaç - bazik bileşimli damar kayaları kuvars diyorit ve gabro bileşimi sunmaktadır (Şekil 2d). Damar karakterli bu kayalar 6x1 m boyutlarına ulaşabilmektedir. Makaslama zonlarından kurtulmuş, düşük deformasyonlu alanlarda ilksel magmatiğe ait kalıntı holokristalen hipidiomorf doku gözlenmektedir. Bu bazik kayalar makaslama zonlar1 boyunca kuvvetli foliyasyon gösteren amfibolitlere dönüşmüşlerdir. Amfibolitler arazide zor seçilen ufak granat kristalleri içermektedir. Asidik bileşimli magmatikler, aplit - pegmatit bileşimli olup $3 \times 1$ metre boyutlarında damar 
kayaçları niteliğindedir. Arazide bu damarların çevre kayaçlarını oluşturan yüksek dereceli şistlerin bölgesel foliyasyonunu keser durumda olduğu net olarak gözlenmektedir (Şekil 3). Bazı kesimlerde ise üzerleyen Alpin metamorfizması sonucu damarların kıvrımlandığı ve şistoziteye paralel veya kismen paralel hale geldikleri görülmektedir (Şekil 2c).
Emirgazi Formasyonu Ormancık, Sarıăaç, Karalarbahşiş, Asar, Güney ve Narince köyleri arasında kuzeybatı -güneydoğu uzanımlı olarak yer alan formasyon çalışma alanının yaklaşık yarısını kaplamaktadır. Baskın olarak açık yeşilkirli sar1 renkli klorit-albit şistlerden oluşur (Şekil 2e). Bu düşük dereceli şistler, kahverengi ayrışma renkli dolomit (Şekil 2f), mor - beyaz

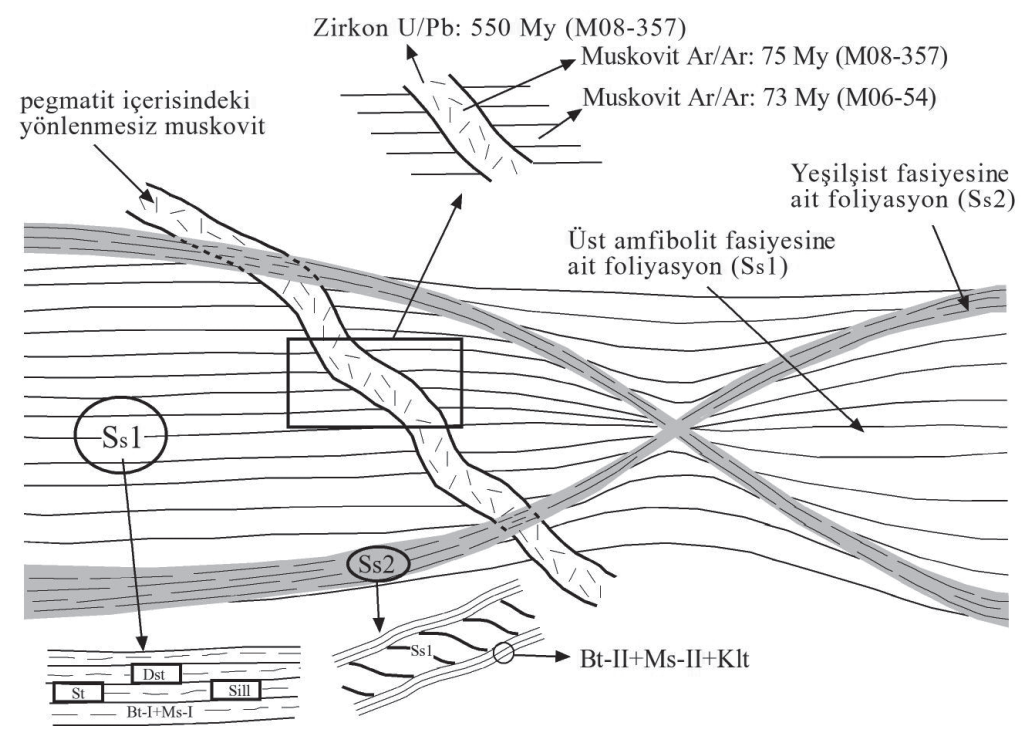

Şekil 3. Sarıăgaç birimi içerisinde gözlenen $\mathrm{S}_{\mathrm{s}} 1$ ve $\mathrm{S}_{\mathrm{s}} 2$ foliyasyonları. Üst amfibolit fasiyesi koşullarında gelişmiş olan Ss1 foliyasyonu sırasıyla pegmatit damarı ve $\mathrm{S}_{\mathrm{s}} 2$ foliyasyonu (yeşilşist fasiyesi) tarafından kesilmekte (şematik). Dst: disten, St: stavrolit, Sill: sillimanit, Bt: biyotit, Ms: muskovit, Klt: klorit.

Figure 3. $S_{S} 1$ and $S_{S} 2$ foliations observed in the Sarıagaç unit. The $S_{S} 1$ foliation developed in the upper amphibolite facies is cut by the pegmatite vein and $S_{\mathrm{s}} 2$ foliation (greenschist facies), respectively (schematic). Dst: kyanite, St: staurolite, Sill: sillimanite, Bt: biotite, Ms: muscovite, Klt: chlorite.

\section{Kapıdă̆ Napı}

Sünümlü koşullarda gelişmiş tektonik bir dokanakla Sarıăaç Birimi’ni üzerleyen Kapıdağ nap'1 alttan üste doğru, düzenli ve kesiksiz bir istifi tanımlayan, iç ekaylanmalı Emirgazi (Kozlu 1990; Özgül ve Kozlu 1992), Hüdai (Dean ve Özgül, 1994), Çaltepe (Dean ve Monod, 1970; Özgül ve Gedik, 1973; Monod 1977) ve Seydişehir Formasyonlarından (Dean ve Monod, 1970; Monod 1977) oluşmaktadır. muskovit-kuvars şist ve koyu gri mermer mercek ve düzeyleri içermektedir. Yaygın budinli bir yap1 gösteren kahverengi dolomitler kuvarsitle ardalanan, kalınlıkları 1-40 m arasında değişen düzeyler şeklinde bulunmaktadır. Arazide belirgin morfolojiler oluşturan muskovit-kuvars şistler mor - beyaz renkli, homojen kayalar olup kalınlığı 60 metreye kadar ulaşan düzeyler oluşturur. Kuvarsarenitik kumtaşlarından türemiş bu şistler içerisinde, ilksel killi düzeylere karşılık gelen, birkaç milimetre kalınlığında beyaz mikaca zengin düzeyler gözlenmektedir. 
Emirgazi Formasyonu kalınlığı 130 metreye varan, homojen bir içyapıya sahip muskovitkuvars şistlerden oluşan Hüdai Formasyonu tarafından üzerlenmektedir. Dokanak çoğu yerde örtülüdür. Gerek bölgesel ölçekte gerekse dokanak boyunca iki birim geçirdikleri ortak metamorfizma nedeniyle birbirlerine paralel foliyasyon kazanmışlardır. $\mathrm{Bu}$ metamorfizma nedeniyle olasılı bir ilksel uyumsuzluğu tanımlayabilecek sedimantolojik veriler tümüyle silinmiştir. Karaağaçlıpınar Mevkiinde ise bu iki birim arasındaki dokanak faylıdır (Şekil 1b). Yanal yönde yaklaşık $1.5 \mathrm{~km}$ uzanım gösteren, düşey atımlı fay kırılgan deformasyon özellikleri göstermektedir (Şekil 1b). Hüdai Formasyonuna ait muskovit-kuvars şistlerde, ilksel kuvarsarenitlere ait metamorfizmadan korunmuş çapraz katmanlanma ve laminalanma yapıları gözlenebilmektedir. Özellikle Kesme Tepenin güney etekleri boyunca çapraz katmanlanma gösteren meta-kuvars kumtaşları yaygın olarak bulunmaktadir.

Hüdai Formasyonu uyumlu olarak bir karbonat kaya düzeyi ile üzerlenir. Çaltepe Formasyonu olarak adlandirilan bu karbonat kayaçlar, tabanda görünür kalınlığ 1 yaklaşık 150 m olan koyu gri renkli dolomitlerle başlamaktadır. Dolomitlerin tabanında yaklaşı 10-15 metre kalınlığında çört bant ve nodüllü bir düzey yer alır (Şekil 2g). Görünür kalınlığı yaklaşık 110 m olan, alt düzeyleri masif görünümlü, üst düzeyleri laminalanma gösteren beyaz renkli mermerler, gri dolomiti uyumlu olarak üzerlemektedir. İri kalsit kristalli bu mermer içerisinde yanal ve düşey yönde yamalar şeklinde dolomitleşmeler gözlenir. Laminalı beyaz mermerler yaklaşık 10$12 \mathrm{~m}$ kalınlığındaki kılavuz düzey niteliğinde olan pembe renkli, kil arakatkılı yumrulu mermerler tarafindan üzerlenir. Yumrulu mermerler, pembe renklikarbonatyumruları(Şekil2h)vebuyumruları saran, ilksel maddesi karbonat-kil olan mikaşistkalkşist arakatkılarından oluşmaktadır. Şiddetli sünümlü deformasyon nedeniyle yumrularda şiddetli uzamalar ve difüzif sınırlar gelişmiştir. Kırmızı yumrulu mermerler dereceli bir şekilde alt kesimleri kırmızı yumrulu mercek arakatkılı olan klorit fillit, klorit-albit fillit den oluşan homojen bir iç yapıya sahip Seydişehir Formasyonu tarafından üzerlenmektedir. Seydişehir Formasyonu ait fillitler içerisinde ilk 40 metrede kalınlıkları 0.5 - $2.5 \mathrm{~m}$ arasında değişen 5 düzey halinde pembe yumrulu mermerler bulunmaktadır. Son pembe yumrulu mermer düzeyinin üzerinde masif fillitler yer almaktadır.

\section{PETROGRAFİ VE MINERAL KIMYASI}

\section{Sarıăgaç Birimi}

Sarıağaç birimi Alanya Masifi'nde üst amfibolit koşulları altında gelişmiş yüksek sıcaklık metamorfizmasının gözlendiği tek birimdir. Sarıăgaç birimi mika şist ve bunun içine sokulmuş asid - ortaç - bazik karakterli damar kayalarından oluşmaktadır. $\mathrm{Bu}$ kayaçlara ait petrografik özellikler aşağıda verilmektedir.

Sarıăgaç birimine ait şistlerde $\mathrm{S}_{\mathrm{S}} 1$ ve $\mathrm{S}_{\mathrm{S}} 2$ olarak adlandirılan 2 foliyasyon mevcuttur (Şekil 3). M1 metamorfizması ile ilişkili olan $\mathrm{S}_{\mathrm{S}} 1$ foliyasyonu sillimanit stavrolit, disten, granat ve biyotit-I ( \pm muskovit-I) minerallerinin birkaçı veya tümü ile temsil edilir. M2 metamorfizmasının ürünü olan $\mathrm{S}_{\mathrm{S}} 2$ foliyasyonu ise klorit, biyotit-II ve muskovit-II mineralleri ile tanımlanır. Arazide gözlenen baskın foliyasyon $\mathrm{S}_{\mathrm{S}} 2$ foliyasyonu tarafindan oblik olarak kesilen $\mathrm{S}_{\mathrm{S}} 1$ foliyasyonudur.

Sarıăaç birimi içerisinde toplam kaya kimyası kontrollu, beş farklı mineral topluluğuna sahip parajenez ayırt edilmiştir. Bunlardan en önemlilerden birini 'disten + biyotit-I + granat + plajiyoklaz + kuvars + muskovit-I + biyotit $I I+$ muskovit-II + klorit + opak mineral' genel mineral bileşimine sahip olan disten-granat-biyotit şistler oluşturur (Çizelge 1, M09-65/1) Akine Köyü'nün kuzey batısında ve Sarıăaç Köyü'nün güneydoğusunda yaygın olarak gözlenir. S-C 
yapılarının belirgin olarak gözlendiği örnekte $\mathrm{S}$ yapıları $\mathrm{S}_{\mathrm{S}} 1$ ile $\mathrm{C}$ ise $\mathrm{S}_{\mathrm{S}} 2$ ile temsil edilir (Şekil 4a-b). $\mathrm{S}_{\mathrm{S}} 1$ foliyasyonu içerisinde, boyları 500 mikronu geçmeyen ve yarı özşekilli olarak gözlenen granat kristalleri kuvars, plajiyoklaz ve muskovit kapanımlıdır. Çekirdekten kenara doğru pirob $\left(\mathrm{X}_{\mathrm{Prp}}\right)$ ve almandin $\left(\mathrm{X}_{\mathrm{Alm}}\right)$ içeriği bakımından artış buna karşın spessartin $\left(\mathrm{X}_{\mathrm{Sps}}\right)$ bakımından azalma gösteren granatlar tek aşamalı büyüme zonlanması gösterirler (Şekil 5a). Almandince zengin olan granatların çekirdekten kenara doğru uç üye bileşim değişimi $\mathrm{Alm}_{(59-}$ ${ }_{65)} \mathrm{Grs}_{(26-21)} \operatorname{Prp}_{(9-14)} \mathrm{Sps}_{(4-1)}$ şeklindedir (Şekil 5c). Grossular $\left(X_{\text {Grs }}\right)$ değeri çekirdekten $(0.26)$ kenara (0.21) doğru azalma eğilimi gösterir. Buna karşın plajiyoklazların anortit içerikleri çekirdekten (0.29) kenara (0.36) doğru artış göstermektedir. Biyotit ve muskovit kapanımları içeren plajiyoklazlar $\mathrm{S}_{\mathrm{S}} 1$ foliyasyon alanı içerisinde dengededir. Kayaç içerisinde gözlenen baskın mika türü biyotittir. Flogopit $\left(\mathrm{X}_{\mathrm{Mg}}=0.57\right.$ 0.60) (Şekil 5d) uç üyesi bakımından zengin olan biyotit-I'in $\mathrm{Al}^{(\mathrm{VI})}$ ve \%Ti değerleri $0.70-1.05$ ve $1.45-2.26$ arasındadır. Biyotit-I ile dokusal olarak birlikte ve dengede bulunan muskovit-I kristalleri $\left(\mathrm{Si}^{(\mathrm{IV})}=3.05-3.07\right) \mathrm{S}_{\mathrm{S}} 1$ foliyasyonunu tanımlayan minerallerden biridir. Boyları 100-350 mikron arasında değişen çubuksu disten kristalleri doku içerisinde dengededir. Distenlerin $\% \mathrm{Al}_{2} \mathrm{O}_{3}$ miktarı 62.73 ile 62.96 arasındadır. Disten-stavrolit-granat şistler 'stavrolit + disten + granat + biyotit-I + biyotit-II + kuvars + plajiyoklaz + klorit + opak mineral' den oluşan genel mineral bileşimine sahiptir (Çizelge 1; M06-50). Ormancık köyünün güney doğusunda ve Sarıăaç köyünün kuzey batısında yaygın olarak gözlenir. Disten, stavrolit ve biyotit-I mineralleri $\mathrm{S}_{\mathrm{S}} 1$ olarak tanımlanan ana foliyasyona paralel uzanırlar ve küçük biyotitII kristalleri ile tanımlanan Ss2 foliyasyonu tarafından kesilir (Şekil 4c-d). Granatlar genellikle özşekilsiz ve boyları 500 mikrondan küçüktür. $\operatorname{Alm}_{(59-71)} \operatorname{Grs}_{(14-27)} \operatorname{Prp}_{(4-13)} \operatorname{Sps}_{(2-10)}$ bileşim aralı̆̆ına sahip olan granatlar almandince zengindir (Şekil 5b-c) (Çizelge 1). Çekirdekten kenara doğru $X_{\text {Sps }}$ miktarındaki azalış buna karşın $X_{\text {Alm }}$ ve $X_{\text {Prp }}$ miktarındaki kesintisiz artış söz konusu granatların tek aşamalı büyüme zonlanması ürünü olduğunu göstermektedir (Şekil 5b). Granatın $X_{\text {Alm }}$ ve $X_{\text {Grs }}$ uç üyeleri çekirdekten kenara doğru ters ilişkili davranış gösterir. $\mathrm{X}_{\text {Grs }}$ miktarındaki azalış sıcaklık fonksiyonunda basınç düşmesiyle ilişkilidir. Granatın kristal yapısına giremeyen $\mathrm{Ca}$, büyük olasılıkla Ca bakımından daha zengin plajiyoklaz olarak kristalleşmiştir (Tuccillo ve diğ. 1990). Bu durum örneklerdeki Na'ca zengin çekirdek $\left(\mathrm{An}_{04}\right)$ ve Ca bakımından zengin kenar $\left(\mathrm{An}_{44}\right)$ kesimine sahip zonlu plajiyoklazların varlığı ile desteklenir (Şekil 4e) (Çizelge 1). Anortit bakımından zengin plajiyoklazın gelişimi

grossular + Al-silikat (disten $)+$ kuvars $=$ anortit

reaksiyonu ile gerçekleşir. Grossuların reaksiyonun (1) yüksek basınç tarafinda kalmasından dolayı, granat büyümesiyle birlikte grossular içeriğindeki azalış basınç düşmesini tanımlamaktadır (Tuccillo ve diğ. 1990). M06-50 nolu örnekte dokusal ilişkiler distenin kısmen stavrolitle yer değiştirdiğini göstermektedir (Şekil 4f-g). Oldukça dar sıcaklık basınç aralığında gerçekleşen bu yer değiştirmede yeni bir foliyasyonun gelişmemiş olması bu replasmanın statik koşullar altında gerçekleştiğini göstermektedir. Distenin duraylılığını kaybedip yerini stavrolite birakmas1

stavrolit + kuvars $=$ Al-silikat $($ disten $)+$ granat + $\mathrm{H}_{2} \mathrm{O}$

stavrolit + kuvars $+\mathrm{O}_{2}=$ Al-silikat (disten) + magnetit $+\mathrm{H}_{2} \mathrm{O}$

reaksiyonları (Hoschek 1969) tarafindan gerçekleşebildiği gibi orta ve yüksek basınçlarda doğrudan 'stavrolit $+S i+T i+O=\underline{\text { Al-silikat }}$ $\underline{\text { (disten })}+$ hersinit + ilmenit $+\mathrm{Al}+\mathrm{Fe}+\mathrm{Mg}$ $+\mathrm{Mn}+\mathrm{Zn}+\mathrm{OH}$ ' dönüşümü şeklinde de meydana gelebilmektedir (Fox 1975). M0650 nolu örneğe ait distenlerin $\% \mathrm{Al}_{2} \mathrm{O}_{3}$ miktarı 
(59.18 - 59.22) stavrolit içermiyen M09-65/1 nolu örneğe göre daha azdır. \%51.15 - 54.31 oranında $\mathrm{Al}_{2} \mathrm{O}_{3}$ içeriğine sahip olan stavrolitlerin $\mathrm{X}_{\mathrm{Mg}}(=\mathrm{Mg} / \mathrm{Fe}+\mathrm{Mg})$ oranı $0.18-0.21$ arasındadır. Plajiyoklazdan sonra bolluk olarak ikinci sirada yer alan biyotit-I'in annit uç üyesi, ortalama $\mathrm{Al}^{(\mathrm{VI})}$ miktarı ve maksimum $\mathrm{X}_{\mathrm{Mg}}$ değeri sirasıyla 48-50, 0.88 ve 0.52 dir (Şekil 5d). Biyotit-I ile biyotit-II arasında kristal boyutu farkı haricinde en büyük fark Ti içeriklerindedir. Biyotit-I \%1.71 - $2.23 \mathrm{TiO}_{2}$ içeriğine sahipken biyotit-II de bu miktar $\% 0.46-0.93$ aralığındadır. $\mathrm{S}_{\mathrm{S}} 2$ foliyasyon alanlarında gözlenen kloritler Mg-Fe klorit türü olan ripidolit ve pycnoklorit bileşimindedir.

Genel mineral bileşimi 'sillimanit + disten + granat + biyotit-I + biyotit-II + plajiyoklaz + kuvars + klorit + opak mineral'den oluşan sillimanit-disten-granat şistler (Çizelge 1; M08376/2) Akine Köyü'nün kuzeybatısında ve Kulak mahallesinin batısında yer alır. Oldukça nadir olarak gözlenen sillimanitlerin kayaç içerisindeki bolluk oran $\% 1$ 'in altındadır. Biyotit / feldispat dokanağında, feldispatın içine doğru büyümüş iğnemsi küçük kristaller şeklinde gözlenirler (Şekil 4h). 'sillimanit + disten + granat + biyotit-I + plajiyoklaz + kuvars' dan oluşan mineral topluluğu $\mathrm{S}_{\mathrm{S}} 1$ foliyasyonu ile tanımlanan alan üzerinde kristalleşmiştir. Kayaç içerisinde sillimanit olmasına karşın disten tane sınırları keskindir. $\mathrm{Bu}$ durum kayacın disten-sillimanit polimorfik dönüşüm sınırına yakın veya üzerinde bir yerde metamorfizmaya uğramış olabileceğini göstermektedir. Doku içerisine dağılmış çubuksu kristaller şeklinde görülen distenler yarı özşekillidir. Biyotit-I, plajiyoklaz ve kuvars kapanımları içeren granatların boyları genellikle 500 mikronu geçmemektedir. Klorit ve biyotitII mineralleri ile temsil edilen $\mathrm{S}_{\mathrm{S}} 2$ foliyasyon alanlarında biyotit-I'in klorite dönüşümü ve granatların çatlak ve kenarları boyunca kloritleşme gösterdiği gözlenmektedir.

Sarıăaç birimi içerisindeki en yaygın litoloji granat-biyotit şistlerdir. Bunların genel mineral bileşimi 'granat + biyotit-I + biyotit-II + plajiyoklaz + kuvars + muskovit-I + muskovitII + klorit + opak mineral'den oluşur (Çizelge 1, M08-345/6). $\mathrm{S}_{\mathrm{S}} 1$ foliyasyonu oblik kesen makaslama bantlarında $\left(\mathrm{S}_{\mathrm{S}} 2\right)$ biyotitler (biyotit-I) klorite dönüşüm gösterir. Granatlarda basınç gölge alanlarının bulunmayışı bunların biyotit-I foliyasyonu $\left(\mathrm{S}_{\mathrm{S}} 1\right)$ ile eş yaşlı veya sonrasında oluştuğunu göstermektedir.

Granat-muskovit şist olarak adlandırılan M06-54 nolu örnekte 'granat + muskovit-I + muskovit-II + albit + kuvars + klorit + epidot + rutil + opak mineral' den oluşan mineral bileşimi ayırt edilmiştir (Çizelge 1). Bu örneği diğer örneklerden ayıran en büyük özellik muskovitI'in (fengit) yüksek $\mathrm{Si}\left(\mathrm{Si}^{4+}=3.41-3.50\right)$ içeriğgi ve kayaçta stavrolit ve biyotit' in mevcut olmamasıdır. $\mathrm{Bu}$ durum büyük olasıl1kla kayacın toplam kayaç kimyası ile ilişkilidir (Çizelge 2). Distenstavrolit-granat şist (M06-50) ve disten-granatbiyotit şist (M09-65/1) örneklerinde toplam kayaç kimyası içerisindeki XFe miktarı granat-muskovit şist'e (M05-54) göre daha düşüktür. Demir bakımından zengin $\left(\mathrm{X}_{\mathrm{Fe}}=0.74\right)$ toplam kayaç kimyasına sahip olan pelitik kökenli kayaçlarda stavrolit duraylılı̆̆ını yitirmesiyle granat ve muskovitten oluşan bir topluluğa dönüşmektedir (Mc Lellan 1985). Stavrolitin mineral formulünde yer alan yüksek miktardaki alüminyum disten yerine yüksek Si içerikli beyaz mikayı tercih etmektedir. $\mathrm{Bu}$ nedenle disten kristalleşmesi gerçekleşmemektedir (Mc Lellan 1985). Ayrıca kayacın yüksek $\mathrm{Fe}$ içeriğinden dolayı biyotit kristalleşmesi meydana gelmediğinden ortamda bulunan titanyum rutil olarak kristalleşmektedir (Meinhold 2010). $\mathrm{S}_{\mathrm{S}} 1$ foliyasyonunu tanımlayan muskovit-I kristallerinin boyu 300 mikrona kadar ulaşmaktadır. Boyları 120 mikrona kadar olan düşük Si içerikli $\left(\mathrm{Si}^{4+}=3,06-3,12\right)$ muskovit-II $\mathrm{S}_{\mathrm{S}} 2$ foliyasyonunun etki alanında mevcuttur. $\mathrm{Bu}$ örnekten yapılan beyaz mika Ar-Ar yaş tayininden $73.72 \pm 0.8$ my'lık plato yaşı elde edilmiştir (Şekil $8 a)$. 

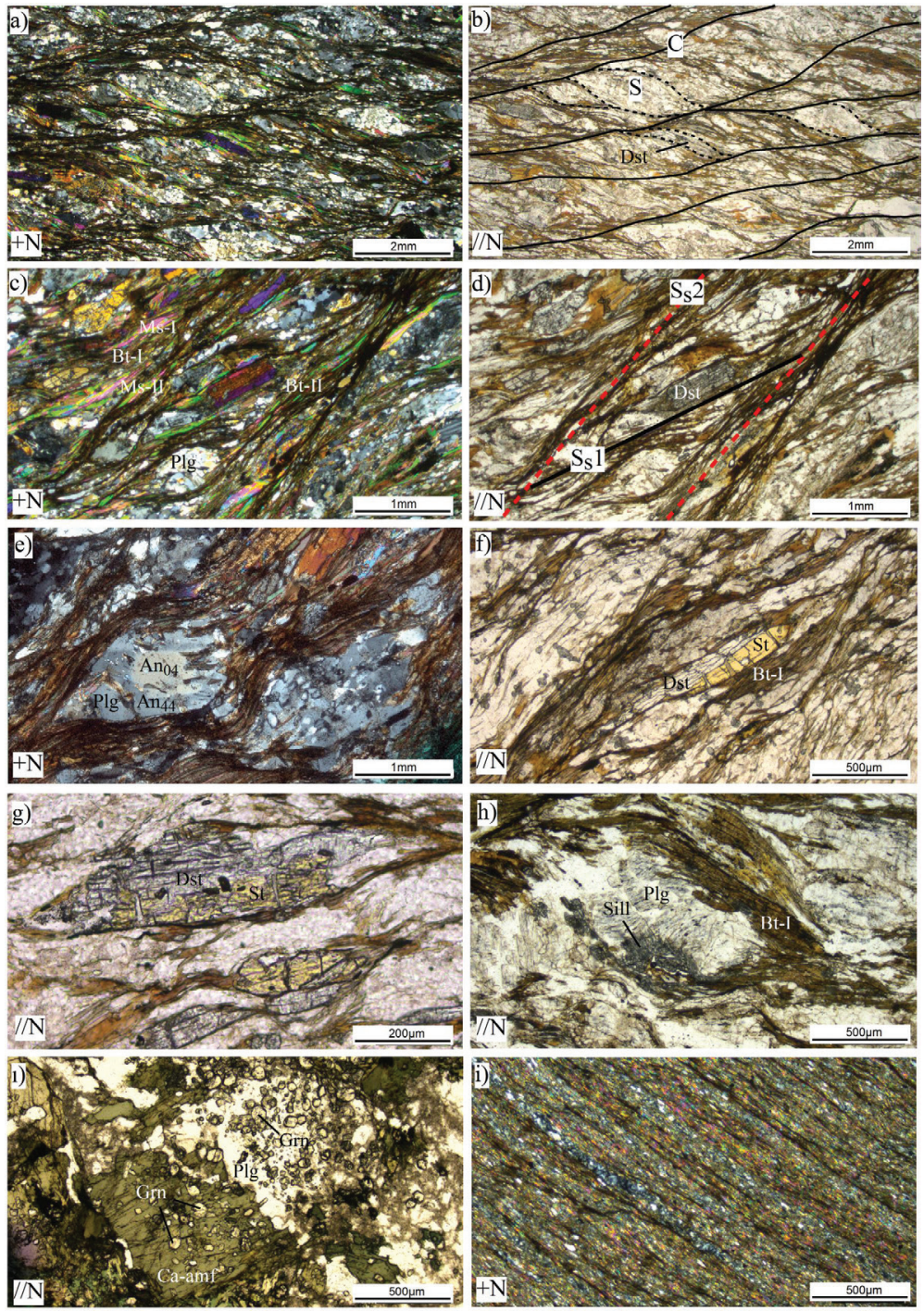

Şekil 4. a-b)Sarıăgaç birimi içerisinde yer alan disten-granat-biyotit şist'de gözlenen S-C yapılarının haç ve paralel nikol görüntüleri. $\mathrm{S}$ ve $\mathrm{C}$ yapıları sırasıyla $\mathrm{S}_{\mathrm{S}} 1$ ve $\mathrm{S}_{\mathrm{S}} 2$ foliyasyonunu temsil etmektedir, c-d) Disten-stavrolit-granat şist'de Ss1 foliyasyonuna paralel büyümüş disten, muskovit-I ve biyotit-II kristallerini kesen Ss2 foliyasyonuna ait haç ve paralel nikol görüntüleri, e) plajiyoklaz kristallerinde gözlenen kimyasal zonlanma, f-g) Distenin stavrolit tarafından kısmi yer değişimi, h) feldispatın içine doğru büyüme gösteren yüksek röliyefli sillimanit kristalleri, 1) plajiyoklaz ve Ca-amfibol içerisinde gözlenen özşekilli granat kristalleri, i) Emirgazi Formasyonu içerisinde yer alan muskovit-klorit şistlere ait genel doku görüntüsü. Dst: disten, St: stavrolit, Sill: sillimanit, Bt: biyotit, Ms: muskovit, Klt: klorit, Plg: plajiyoklaz, An: anortit, Grn: granat, Ca-amf: kalsiyum amfibol

Figure 4. $a-b)+N$ and $/ / N$ images of $S$-C structures observed in the kyanite - garnet-biotite schist located in the Sarlağaç unit. $S$ and $C$ represent the foliation $S_{S} 1$ and $S_{S} 2$ respectively $\left.c-d\right)+N$ and $/ / N$ images of $S_{S} 2$ foliation which cuts the kyanite, muscovite-I and biotite-II crystals parallel to Ss 1 foliation in kyanite-staurolite-garnet schist, e) chemical zonation in plagioclase crystals, $f$-g) partial replacement of kyanite by saturolite, $h$ ) sillimanite crystals with high relief showing growth into feldspar, i) euhedral garnet crystals observed in plagioclase and Ca-amphibole crystals, i) general texture of muscovite-chlorite schists in Emirgazi Formation. Dst: kyanite, St: staurolite, Sill: sillimanite, Bt: biotite, Ms: muscovite, Clt: chloride, Plg: plagioclase, An: anorthite, Grn: garnet, Ca-amf: calcium amphibole 
a)

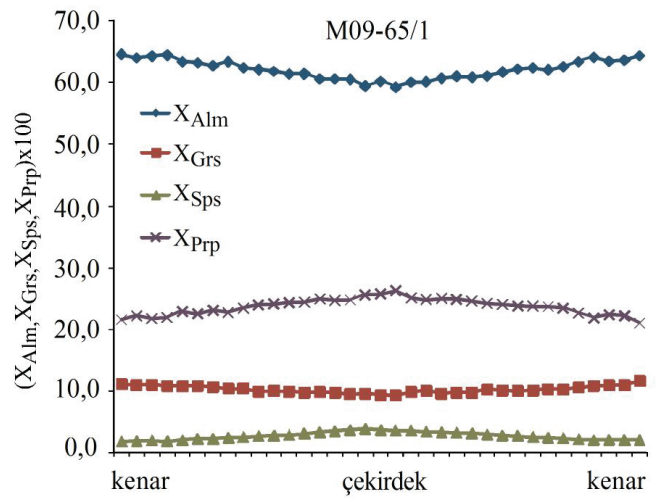

c)

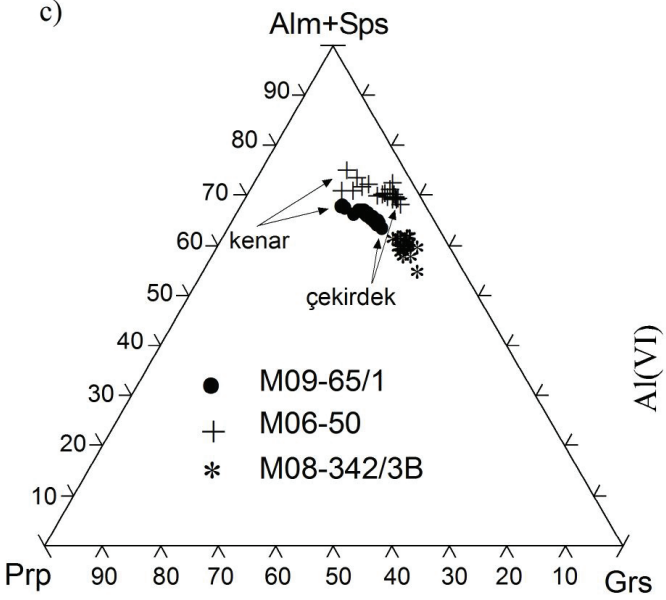

b)

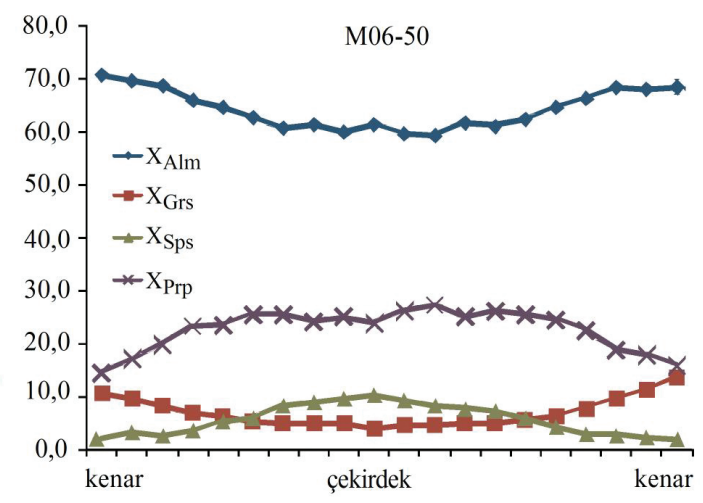

d)

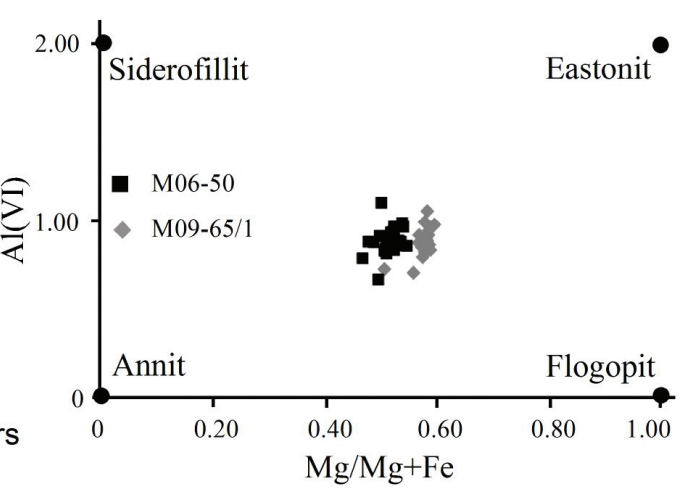

e)

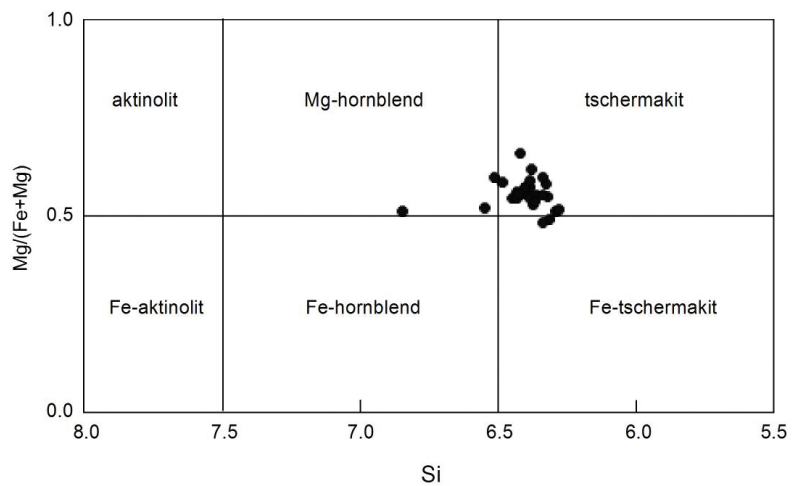

Şekil 5. Tek aşamalı büyüme zonlanması ve çekirdekten kenara doğru $X_{\text {Grs }}$ miktarında azalma gösteren (a-c) distengranat-biyotit şist (M09-65/1) ve (b-c) disten-stavrolit-granat şist (M06-50), d) M09-65/1ve M06-50 nolu örneklerde biyotit-I bileşimi, e) M08-342/3B nolu örnekte yer alan Tschermakit bileşimli Ca-amfiboller. Diyagram Leake et al. (1997) den alınmıştır.

Figure 5. (a-c) kyanite-garnet-biotite schist (M09-65/1) and (b-c) kyanite-staurolite-garnet schist (M06-50) show single-stage growth zonation and decreasing from core to rim in $X_{\text {Grs. }}$ d) biotite-I composition belonging to M0965/1and M06-50, e) Ca-amphiboles in Tschermakite composition belonging to M08-342/3B. Diagram has been taken from Leake et al. (1997). 
Damar kayaçları metagabro, meta-diyorit, meta-kuvars diyorit, meta-aplit ve pegmatitlerden oluşmaktadır. Meta-kuvars diyoritler 'Ca-amfibol + plajiyoklaz + kuvars + granat + klorit + epidot + opak mineral' den oluşan genel mineral bileşimine sahiptir (Çizelge 1, M08-342/3B). Masif yapılı bu kayaçlarda statik yeniden kristallenme nedeniyle belirgin yönlenme mevcut değildir. Ancak ilksel magmatik dokuya ait özellikler büyük oranda silinmiştir. Kayaç içerisinde \% 40 dan fazla bir orana sahip plajiyoklazlarda $\left(\mathrm{An}_{21-25}\right)$ serizitleşme yaygındır. Bunun sonucu olarak plajiyoklazlar kenardan çekirdeğe doğru ve çatlaklar boyunca bulutsu bir görünüm kazanmıştır. Boyları 2-3 mm kadar ulaşabilen Ca-amfibol porfiroblastları kuvars ve granat kapanımları içermektedir. Caamfiboller baskın olarak düşük Si içerikli amfibol olan Tschermakit bileşimine sahiptir (Şekil 5e). Plajiyoklaz ve Ca-amfibol içerisinde boyları 200 mikronu geçmeyen, çok sayıda, özşekilli granat kapanımları yer alır (Şekil 41). Granat uç üyelerinin bileşim aralığı $\mathrm{Alm}_{(53-61)} \mathrm{Grs}_{(22-34)} \operatorname{Prp}_{(9-14)} \mathrm{Sps}_{(1-3)}$ dır. Plajiyoklazdan itibaren gelişmiş serizit alanları üzerinde kristalleşmiş olan epidotların $\mathrm{X}_{\mathrm{Ps}_{\mathrm{s}}}\left(=\mathrm{Fe}^{3+}\right.$ / $\left(\mathrm{Fe}^{3+}+\mathrm{Al}-2\right)$ ) miktar1 $0.61-0.75$ arasindadir. M08342-3B nolu örnekte geri dönüşüm plajiyoklazın serizite ve epidota, Ca-amfibolün klorite ve granat'ı Ca-amfibole dönüşümüyle temsil edilir. Ca-amfibolün kristal sınırları içerisinde büyümüş olan granatlar kenardan çekirdeğe doğru Caamfibol ilekısmen veya tamamen yer değiştirmiştir. Granat ile yer değiştiren amfibolle porfiroblastik amfibolün kimyası tümüyle aynıdır. Ca-amfiboller Tschermakit bileşimli olup brunsvigit türü kloritle yer değiştirmektedir.

Meta-gabroların genel mineral bileşimleri 'Ca-amfibol \pm granat + plajiyoklaz + epidot + klorit + sfen + serizit + opak mineral' olarak saptanmıştır (Çizelge 1, M08-341/1). Nematoblastik doku içinde homojen bir dağılım sunan granatlar yarı özşekillidir ve boyları 100300 mikron arasındadir. Granatlar epidot ve zoisit, magmatik piroksen ise tümüyle hornblend tarafından replase edilmiştir. Kayacın sosuritleşme derecesine bağlı olarak plajiyoklazların kenarları, ikiz lamelleri ve kırıkları boyunca kısmen veya tamamen serizite dönüşüm gözlenir. Metagabrolarda kaya içerisinde saçılmış epidotların yanı sıra damar karakterinde epidotlar da gözlenir. Epidot damarları üzerine dik olarak büyümüş ince ve çubuksu Ca-amfiboller mevcuttur.

Meta-gabrolara oranla plajiyoklazca daha zengin olan meta-diyoritler 'Ca-amfibol + granat + plajiyoklaz + sfen + klorit + epidot + serizit + kuvars + opak mineral' bileşimine sahiptir (Çizelge 1, M08-342/3A). Meta-gabrolarla benzer dokusal ve mineralojik özelliklere sahiptir.

Pegmatitler (M08-341/5) 'plajiyoklaz + kuvars + muskovit-II + epidot', Meta-aplitler (M08-357) ise 'plajiyoklaz + kuvars + opak mineral' den oluşan mineral bileşimine sahiptirler (Çizelge 1). Plajiyoklaz ve kuvarsın baskın olduğu bu kayaçlarda plajiyoklazlar serizitleşmeden etkilenmişlerdir. Bu nedenle kirli görünüme sahip olan bu plajiyoklazların üstünde, dilinime paralel büyümüş küçük serizit kristalleri gözlenir. Ayrıca plajiyoklazlar kenardan çekirdeğe doğru çubuksu küçük epidot kristallerine dönüşmüştür.

\section{Kapıdă̆ Napı}

Kapıdağ napına ait şistlerde $\mathrm{S}_{\mathrm{K}} 1$ olarak adlandırılan foliyasyon mevcuttur. Klorit, muskovit ve \pm biyotit mineralleri ile temsil edilen $\mathrm{S}_{\mathrm{K}} 1$ foliyasyonu, Sarıăaç birimini de etkilemiş olan Barrov tipi metamorfizmaya ait foliyasyonu tanımlayan $\mathrm{S}_{\mathrm{S}} 2$ foliyasyonunun eşleniğidir.

Barrov tipi, düşük yeşilşist fasiyesi koşullarında metamorfizmaya uğramış olan Emirgazi, Hüdai, Çaltepe ve Seydişehir formasyonlarına ait şistlerin petrografik özellikler aşağıda verilmektedir.

Emirgazi Formasyonu'nda baskın litolojiyi oluşturan muskovit-klorit şistlerin genel mineral bileşimi 'klorit + muskovit \pm albit \pm biyotit + kuvars 
+ opak mineral' den oluşur (Şekil 4i) (Çizelge 1, M06-46). Lepidoblastik doku özellikleri gösteren bu kayaçlarda, $\mathrm{S}_{\mathrm{K}} 1$ foliyasyonu klorit ve muskovit minerallerinin yönelimleriyle tanımlanmaktadır. Kayacı oluşturan kristallerin tane boyotu 100 mikronun altındadır.

Hüdai Formasyonuna ait meta-kuvarsitlerin genel mineral bileşimi 'kuvars + plajiyoklaz + muskovit + opak mineral' olarak belirlenmiştir (Çizelge 1, M09-52/2). Granoblastik dokunun hakim olduğu kayaçta, dalgalı sönme ve alt tane sınır oluşumları gösteren kuvarslar modal bileşimin \%95'ini oluşturur. Buna karşın muskovitin çok az olması ve bu mineralin doku içerisinde homojen dağılımı nedeniyle belirgin bir foliyasyon gelişmemiştir. Opak minerallerin modal oranı yersel olarak \%20' ye kadar çıkabilmektedir.

Çaltepe Formasyonuna ait kırmızı yumrulu mermerlerin genel mineral bileşimi ' kalsit + albit + muskovit + klorit + kuvars + opak mineral' den oluşur (Çizelge 1, M09-108/1). Bu kayaçlarda çakıllar, granoblastik dokulu saf kalsitten oluşmaktadır. Yumruları saran, kilce zengin düzeylerden türeme ara madde ise yine kalsitçe baskın olmasına karşın muskovit, klorit ve kuvars kristallerince zengindir.

Seydişehir Formasyonunu 'klorit + albit + muskovit + kuvars + opak mineral' den oluşan albit-klorit şistlerle tanımlanmaktadır (Çizelge 1, M09-108/2). Baskin olarak klorit ve albitten oluşan kayaçta albitler kenarlarından itibaren klorite dönüşmüşlerdir.

\section{BASINÇ - SICAKLIK KOŞULLARI}

Asidik bileşimli damar kayaçları tarafından kesilen Sarıăaç birimi yüksek dereceli şist ve amfibolitik metadiyorit kütlelerinden oluşmaktadır. Metabazik ve şistlerde etkilenmiş oldukları çoklu metamorfizma $\left(\mathrm{M}_{\mathrm{S}} 1\right.$ ve üzerleyen $\mathrm{M}_{\mathrm{s}} 2$ ) ve deformasyon nedeniyle $\mathrm{S}_{\mathrm{s}} 1$ ve $\mathrm{S}_{\mathrm{s}} 2$ olarak tanımlanan iki foliyasyon gelişmiştir. Buna karşın aplit ve pegmatit türü asidik magmatik kayaçlarda tek evreli $\left(\mathrm{M}_{\mathrm{s}} 2\right)$ metamorfik tarihçeyi gösterecek şekilde sadece $\mathrm{S}_{\mathrm{S}} 2$ foliyasyonu gözlenmektedir. Sarıăgaç Biriminin çok evreli metamorfik geçmişinin basınç-sıcaklık koşullarına bir yaklaşımda bulunmak amacıyla uygun mineral topluluklarına sahip örneklere, mineral bileşimlerine dayalı geleneksel jeotermobarometrik yöntemler uygulanmıştır. Geleneksel jeotermobarometrik hesaplama yöntemlerinde kullanılan mineral analizleri Çizelge 3'de verilmektedir. Ayrıca iki şist örneğine (M06-50; M09-65/1) M $\mathrm{M}_{\mathrm{S}} 1$ metamorfizmasının koşullarını belirlemek amacıyla 'toplam kaya kimyası - mineral topluluğu' ilişkisine dayalı Theriak- Domino (yazılım yöntemi) yöntemi uygulanmıştır.

Kapıdağ napından yapılan dokusal analizlerde bu topluluğun tek evreli deformasyon geçmişini tanımlayan foliyasyona (Ms1 metamorfizması ile ilişkili Ss1 foliyasyonu) sahip olduğu saptanmıştır. $\mathrm{Bu}$ kaya topluluğundan toplam kaya kimyası ve mikropirob analizleri gerçekleştirilmemiştir. $\mathrm{Bu}$ kayaç topluluğunun metamorfizma derecesi sahip olduğu indeks minerallerin ortaya çıkış/kayboluş koşullarına dayalı olarak tahmin edilmiştir.

\section{Sarıăaç Birimi}

\section{Geleneksel yöntem}

$\mathrm{M}_{\mathrm{S}} 1$ metamorfizmasının sicaklık ve basınç koşullarının belirlenmesi amaciyla disten-stavrolit şist (M06-50) ve meta-kuvarsdiyorit (M08342/3B) örneklerine minerallerin bileşimlerine dayalı jeotermobarometrik kalibrasyon formülleri uygulanmıştır (Çizelge 4). Şist örneğindeki (M06-50) granat-biyotit çiftlerine ait $\mathrm{Fe}-\mathrm{Mg}$ değişim reaksiyonlarına dayalı jeotermometreler (Spear 1993; Kleemann ve Reinhardt 1994; Holdaway 2000) olması gereken sicaklıktan 60 ile $200^{\circ} \mathrm{C}$ daha düşük sıcaklık değerleri vermiştir. Biyotite stavrolitin eşlik ediyor olması 
göz önüne alındığında bu sıcaklık tahminlerinin gerçeği yansıtamayacă̆ 1 açıktır. Buna karşın Perchuk (2004) tarafindan önerilen granatstavrolit jeotermometresi yazilımsal metod ve petrografik gözlemlerle uyumlu olacak şekilde granat (çekirdek) -stavrolit (kenar) ve granat (kenar) -stavrolit (kenar) çiftleri için sırasıyla $632-684^{\circ} \mathrm{C}$ aralığında değişen sıcaklık değerleri vermektedir (Çizelge 4). Ayni örnekteki granat - plajiyoklaz - aluminosilikat (disten) - kuvars (GPAK) jeobarometresinden, öngörülen $650^{\circ} \mathrm{C}$ sıcaklık değerine karşılık olarak 7,2 - 7.6 kbar arasında değişen basınç değerleri elde edilmiştir (Çizelge 4).

Çizelge 1. Sarıăgaç birimi ve Kapıdağ napında yer alan kayaçlara ait mineral topluluğu (Min: Mineral; Örn: Örnek no).

Table 1. The mineral assemblage of the samples from Sarıăgaç unit and Kapıdă̆ nappe (Min: Mineral; Örn: sample no).

\begin{tabular}{|c|c|c|c|c|c|c|c|c|c|c|c|c|c|}
\hline Min./Örn. & $\frac{\mathrm{M} 09-}{\underline{65 / 1}}$ & $\frac{\text { M06- }}{\underline{50}}$ & $\frac{\text { M06- }}{\underline{54}}$ & $\underline{\text { M08- }}$ & $\underline{\text { M08- }}$ & $\begin{array}{l}\underline{\text { M08- }} \\
\underline{342 / 3 B}\end{array}$ & $\underline{\text { M08- }}$ & $\underline{\text { M08- }}$ & $\frac{\text { M08- }}{\underline{357}}$ & $\frac{\text { M06- }}{46}$ & $\frac{\text { M09- }}{\underline{52 / 2}}$ & $\underline{\text { M09- }}$ & $\underline{\text { M09- }}$ \\
\hline Granat & $\mathrm{X}$ & $\mathrm{X}$ & $\mathrm{X}$ & $\mathrm{X}$ & $\mathrm{X}$ & $\mathrm{X}$ & $\mathrm{X}$ & & & & & & \\
\hline Disten & $\mathrm{X}$ & $\mathrm{X}$ & & $\mathrm{X}$ & & & & & & & & & \\
\hline Stavrolit & & $\mathrm{X}$ & & & & & & & & & & & \\
\hline Sillimanit & & & & $\mathrm{X}$ & & & & & & & & & \\
\hline Biyotit-I & $\mathrm{X}$ & $\mathrm{X}$ & & $\mathrm{X}$ & $\mathrm{X}$ & & & & & & & & \\
\hline Biyotit-II & $\mathrm{X}$ & $\mathrm{X}$ & & $X$ & $\mathrm{X}$ & & & & & & & & \\
\hline Biyotit $\left(\mathrm{S}_{\mathrm{K}} 1\right)$ & & & & & & & & & & $\mathrm{X}$ & & & \\
\hline Muskovit-I & $\mathrm{X}$ & & $\mathrm{X}$ & & $\mathrm{X}$ & & & & & & & & \\
\hline Muskovit-II & $\mathrm{X}$ & & $\mathrm{X}$ & & $X$ & & & $\mathrm{X}$ & & & & & \\
\hline Muskovit $\left(\mathrm{S}_{\mathrm{K}} 1\right)$ & & & & & & & & & & $\mathrm{X}$ & $\mathrm{X}$ & $\mathrm{X}$ & $\mathrm{X}$ \\
\hline Klorit & $\mathrm{X}$ & $\mathrm{X}$ & $\mathrm{X}$ & $\mathrm{X}$ & $\mathrm{X}$ & $\mathrm{X}$ & $\mathrm{X}$ & & & $\mathrm{X}$ & & $\mathrm{X}$ & $\mathrm{X}$ \\
\hline Ca-amfibol & & & & & & $\mathrm{X}$ & $\mathrm{X}$ & & & & & & \\
\hline Plajiyoklaz & $\mathrm{X}$ & $\mathrm{X}$ & $\mathrm{X}$ & $\mathrm{X}$ & $\mathrm{X}$ & $\mathrm{X}$ & $\mathrm{X}$ & $\mathrm{X}$ & $\mathrm{X}$ & $\mathrm{X}$ & $\mathrm{X}$ & $\mathrm{X}$ & $\mathrm{X}$ \\
\hline Sfen & & & & & & & $\mathrm{X}$ & & & & & & \\
\hline Rutil & & & $\mathrm{X}$ & & & & & & & & & & \\
\hline Epidot & & & $\mathrm{X}$ & & & $\mathrm{X}$ & $\mathrm{X}$ & $\mathrm{X}$ & & & & & \\
\hline Kalsit & & & & & & & & & & & & $\mathrm{X}$ & \\
\hline Serizit & & & & & & & $\mathrm{X}$ & $\mathrm{X}$ & & & & & \\
\hline Kuvars & $\mathrm{X}$ & $\mathrm{X}$ & $\mathrm{X}$ & $X$ & $\mathrm{X}$ & $\mathrm{X}$ & & $\mathrm{X}$ & $\mathrm{X}$ & $X$ & $\mathrm{X}$ & $\mathrm{X}$ & $\mathrm{X}$ \\
\hline Opak min. & $\mathrm{X}$ & $\mathrm{X}$ & $\mathrm{X}$ & $\mathrm{X}$ & $\mathrm{X}$ & $\mathrm{X}$ & $\mathrm{X}$ & & $\mathrm{X}$ & $\mathrm{X}$ & $\mathrm{X}$ & $\mathrm{X}$ & $\mathrm{X}$ \\
\hline
\end{tabular}

Kısaltma: $\mathrm{S}_{\mathrm{K}} 1$ : Kapıdağ napına ait foliyasyon 
Meta-kuvarsdiyorit örneğine (M08-342/3B) $\mathrm{M}_{\mathrm{S}} 1$ metamorfizmasının basınç-sıcaklık tahminleri için granat-amfibol arasında $\mathrm{Fe}-\mathrm{Mg}$ değişimine dayanan jeotermometre (Graham ve Powel 1984; Krogh Ravna 2000), granat-amfibol-plajiyoklazkuvars jeobarometresi (Kohn ve Spear, 1989) ve amfiboldeki Al içeriğine göre kalibre edilmiş jeobarometre yöntemleri uygulanmıştır (Çizelge 4). Graham ve Powel(1984) ve Krogh Ravna (2000) jeotermometrelerinde, 'granat (kenar) - amfibol (kenar)' çiftleri, 'granat (çekirdek) - amfibol (kenar)' çiftlerine göre daha yüksek sıcaklık (630 - $690^{\circ} \mathrm{C}$ ) ve daha düşük $\mathrm{K}_{\mathrm{D}}$ değerleri vermektedir (Çizelge 4 ). $K_{D}$ değeri ne kadar 1'e yakınsa o oranda dengeye ulaşılmış demektir. Bu nedenle düşük $\mathrm{K}_{\mathrm{D}}$ değerlerine sahip olan granat (kenar) amfibol (kenar)' çiftlerinden elde edilen sicaklık değerlerinin $\mathrm{M}_{\mathrm{s}} 1$ metamorfizmasının maksimum sıcaklık koşullarını yansıtması beklenir. Kohn ve Spear (1989) jeobarometresinden model1-P(Mg) formülüne göre $650^{\circ} \mathrm{C}$ sicaklık öngörüsü için 7.2 ile 8.6 kbar arasında değişen basınç değerleri elde edilmiştir. Sıcaklıktan bağımsız olarak amfibolün toplam Al içeriğine göre kalibre edilmiş olan Hammarstrom ve Zen (1986) ve Schmidt (1992) jeobarometreleri aynı metabazik örneği için sırasıyla $7.6 \pm 0.4$ kbar ve $8 \pm 0.3 \mathrm{kbar}$ basınç değerleri vermiştir (Çizelge 4). Amfiboldeki Al miktarını kullanan bir diğer jeobarometre Anderson ve Smith (1995) dir. Bu kalibrasyonun diğerlerinden fark1, formülde sıcaklık değişkeninin de yer almasıdır. Bu kalibrasyondan, diğer basınç tahminleri ile uyum gösterecek şekilde $8.1 \pm 0.4$ kbar basınç değeri bulunmuştur.
Çizelge 2. Disten-stavrolit-granat şist (M06-50), distengranat-biyotit şist (M09-65/1) ve granat-muskovit şist (M06-54) örneklerine ait toplam kaya kimyası analizleri. $\mathrm{X}_{\mathrm{Fe}}(=\mathrm{FeO} / \mathrm{FeO}+\mathrm{MgO})$.

Table 2. Bulk rock chemistry analyzes of kyanitestaurolite-garnet schist (M06-50), kyanite-garnet biotite schist (M09-65/1) and garnet-muscovite schist (M06-54). $X_{\mathrm{Fe}}(=\mathrm{FeO} / \mathrm{FeO}+\mathrm{MgO})$.

\begin{tabular}{|c|c|c|c|}
\hline & MO6-50 & M09-65/1 & MO6-54 \\
\hline $\mathrm{SiO} 2$ & 60,64 & 56,74 & 62,22 \\
\hline $\mathrm{TiO} 2$ & 0,92 & 0,79 & 0,84 \\
\hline $\mathrm{Al} 2 \mathrm{O} 3$ & 16,58 & 19,41 & 16,44 \\
\hline $\mathrm{FeO}$ & 7,19 & 7,22 & 7,37 \\
\hline $\mathrm{MnO}$ & 0,09 & 0,08 & 0,09 \\
\hline $\mathrm{MgO}$ & 3,54 & 3,65 & 2,56 \\
\hline $\mathrm{CaO}$ & 1,88 & 1,42 & 1,69 \\
\hline $\mathrm{Na} 2 \mathrm{O}$ & 3,18 & 2,02 & 3,13 \\
\hline $\mathrm{K} 2 \mathrm{O}$ & 2,66 & 3,76 & 2,29 \\
\hline K.k & 2,97 & 4,44 & 2,99 \\
\hline Toplam & 99,65 & 99,52 & 99,63 \\
\hline $\mathrm{XFe}$ & 0,67 & 0,66 & 0,74 \\
\hline
\end{tabular}

Dokusal analizler, şistlerde $\quad \mathrm{M}_{\mathrm{s}} 2$ metamorfizmasının 'klorit - muskovit - biyotitII'den oluşan makaslama zonları ( $\mathrm{S}_{\mathrm{S}} 2$ foliyasyonu) ile tanımlandığını göstermektedir. Bu topluluk, üzerleyen metamorfizmanın yeşilşist fasiyesinde geliştiğini göstermektedir. $M_{\mathrm{S}} 2$ metamorfizmasının sicaklık tahmini klorit ve biyotit gibi mineralleri kullanan jeotermometre hesaplamalarına dayalı olarak tahmin edilmiştir (Çizelge 4). M06-50 nolu şist örneğinde granatın üzerine büyüyen ve $\mathrm{S}_{\mathrm{s}} 2$ foliyasyonunu tanımlanan biyotit-II kristallerine Henry ve diğ. (2005) tarafindan önerilen biyotit jeotermometresi uygulanmış ve $440-521^{\circ} \mathrm{C}$ aralığında gruplanan sicaklık değerleri elde edilmiştir. Bu sıcaklık değerleri kayaç içerisinde serbest rutil ve ilmenitin olmaması nedeniyle mininum sıcaklık değerleri olarak kabul edilmiştir. Benzer şekilde Bourdella ve diğ. (2013)'e ait klorit jeotermometresi ile $\mathrm{S}_{\mathrm{s}} 2$ foliyasyonu ile 
uyum içerisinde olan kloritlerden yüzeylemenin son aşamalarına karşılık gelebilecek $379-411^{\circ} \mathrm{C}$ sıcaklık değerleri bulunmuştur. M08-342/3B nolu metabazik örneğindeki $\mathrm{M}_{\mathrm{s}} 2$ ye ait kloritler Bourdella ve diğ. (2013) jeotermometresine dayalı olarak $319-370^{\circ} \mathrm{C}$ aralığında değişen düşük sicaklık değerleri vermiştir. $\mathrm{M}_{\mathrm{s}} 2$ metamorfizmasının basınç koşullarını ait tek veri M08-342/3B nolu örnekten elde edilmiştir. $\mathrm{S}_{\mathrm{s}} 2$ makaslama alanı içerinde bulunan amfibole Hammarstrom ve Zen (1986), Schmidt (1992) ve Anderson ve Smith (1995) kalibrasyonları uygulanmış ve ortalama $5.1 \pm 0.3$ kbar basınç değeri bulunmuştur (Çizelge 4).

\section{Yazılımsal Metod}

Sarıağaç şist biriminin $\mathrm{M}_{\mathrm{s}} 1$ metamorfizmasına ait basınç - sıcaklık koşullarının saptanmasında şistler içerisinde gözlenen Barrov türü almandinamfibolit fasiyesine ait indeks mineraller (stavrolit - disten - sillimanit) belirleyici etkiye sahiptir. $\mathrm{Bu}$ minerallerin her birinin kayaç içerisinde birbirinden bağımsız olarak bulunması veya aynı kayaç içerisinde birlikte gözlenmeleri birimin maruz kaldığı metamorfizma şiddetinin belirlenmesinde anahtar rol oynamıştır. Toplam kayaç kimyası dengesine dayanan TheriakDomino yazılımı (De Capitani ve Brown 1987; De Capitani ve Petrakakis 2010) ile belli basınç ve sıcaklık koşullarında oluşabilecek mineral veya mineral topluluklarının denge alanlarının belirlenmesi hedeflenmiştir. Bu yöntemle Sarıăaç Biriminin içerisinde yer alan şistlerin (M06-50 ve M09-65/1) mevcut mineral topluluklarına göre basınç - sıcaklık koşulları belirlenmeye çalışılmıştır.

'Disten + stavrolit + biyotit + granat + plajiyoklaz + klorit + kuvars + opak min.' bileşimine sahip M06-50 numaralı örneğe ait parajenez denge diyagramı Şekil 6' da verilmektedir. Bu örneğe ait $\mathrm{S}_{\mathrm{S}} 1$ foliyasyonu ile tanımlanan mineral topluluğu 'disten + stavrolit + biyotit-I + granat + albit + kuvars' dan oluşmaktadır. Bu örnekte disten ve stavrolit, her iki mineralin birbirleriyle dengede olduğunu gösterecek şekilde keskin dokanak ilişkisine sahiptir (Şekil 6).

$\mathrm{Bu}$ iki mineralin yanı sıra diğer $\mathrm{S}_{\mathrm{S}} 1$ foliyasyonu minerallerinin de bir arada dengede olduğu alan Şekil 6'da mavi halka içerisinde gösterilmektedir. $\mathrm{Bu}$ alanın stavrolit $\mathrm{Mg \#}(\mathrm{Mg} /$ $\mathrm{Mg}+\mathrm{Fe})$ ve biyotit $\mathrm{Mg} \#(\mathrm{Mg} / \mathrm{Mg}+\mathrm{Fe})$ eş bileşim eğrileriyle daha daraltılması mümkündür. $\mathrm{Bu}$ örnekte stavrolit Mg\# (0.19-0.21) değerleri, basınçtan büyük oranda bağımsız olarak sıcaklık artışıyla artma göstermektedir (Şekil 6). Şekil 6 da verilen parajenez denge diyagramında, biyotit'e ait $\mathrm{Mg \#} \mathrm{(0.48-0.56)} \mathrm{eş} \mathrm{bileşim} \mathrm{eğrileri} 610^{\circ} \mathrm{C}$ üzeri sıcaklıklarda $\mathrm{Mg \#} \mathrm{değerinde} \mathrm{artış} \mathrm{sıcaklık}$ ve basınç artışı birlikteliğinde gözlenir. $\mathrm{Bu}$ durum stavrolitle birlikte distenin ortaya çıkışını desteklemektedir. 


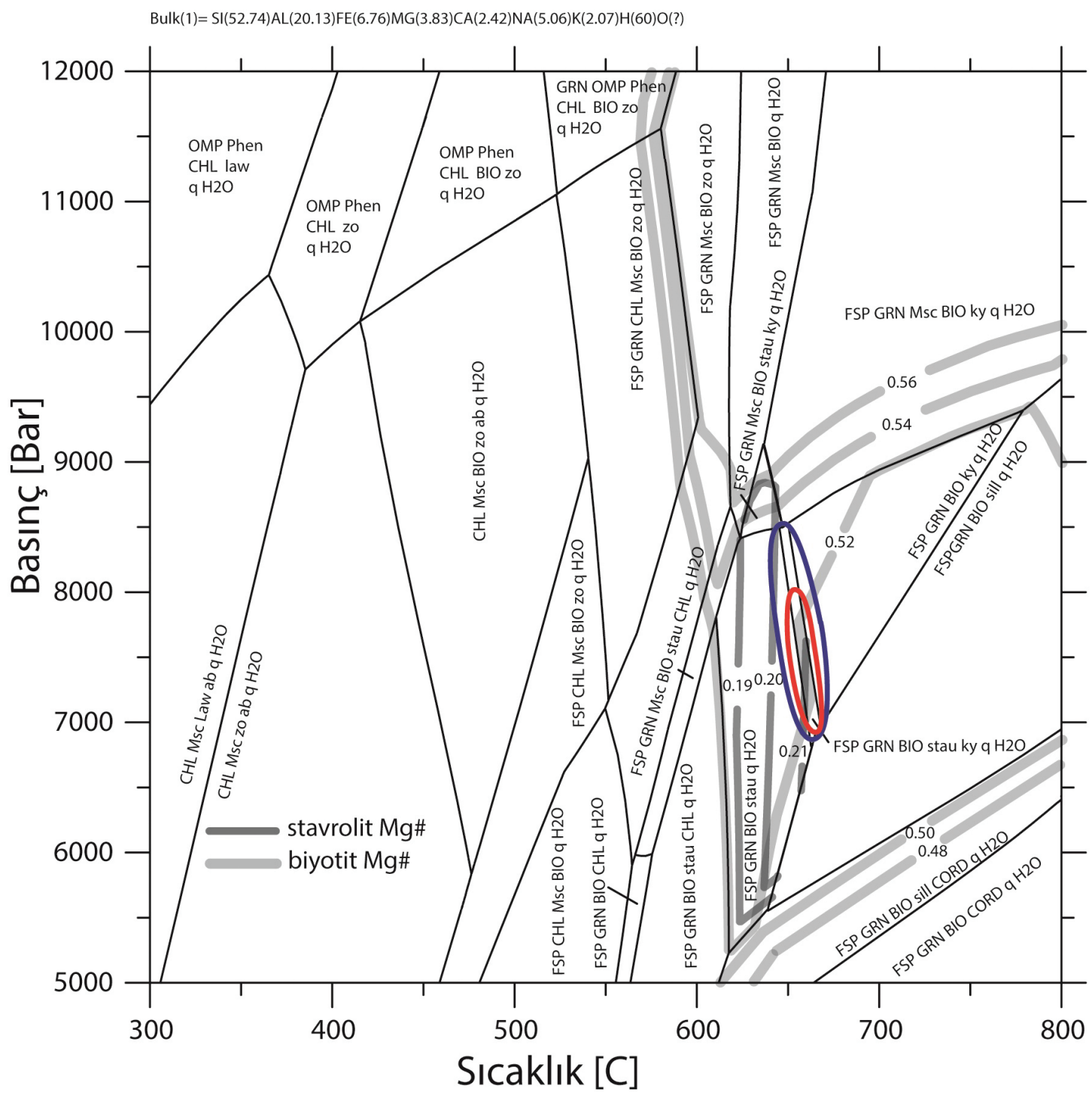

Şekil 6. M06-50 nolu örneğe ait parajenez denge diyagramı. Kırmızı halka stavrolit ve biyotit Mg\# eş bileşim eğrileriyle daraltılmış olan 'granat (GRN) - biyotit (BIO) - stavrolit (STAU) - disten (KY) - kuvars (q) - H20' parajenezinin denge alanını tanımlamaktadır. Sillimanit: sill; Kordiyerit: CORD; Muskovit: Msc; Klorit: CHL; zoisit: zo; Omfasit: OMP; Fengit: Phen; Lavsonit: law.

Figure 6. Paragenesis equilibrium diagram (pseudosection) for M06-50. The red circle which is limited by staurolite and biotite $\mathrm{Mg}$ \# isopleths, describes the equilibrium area of the garnet (GRN) - biotite (BIO) - staurolite (STAU) kyanite (KY) - quartz (q) - H2O paragenesis. Sillimanite: sill; Cordierite: CORD; Muscovite: MSc; Chloride: CHL; Zoisite: zo; Omphacite: OMP; Fengit: Phen; Lavsonit: law 


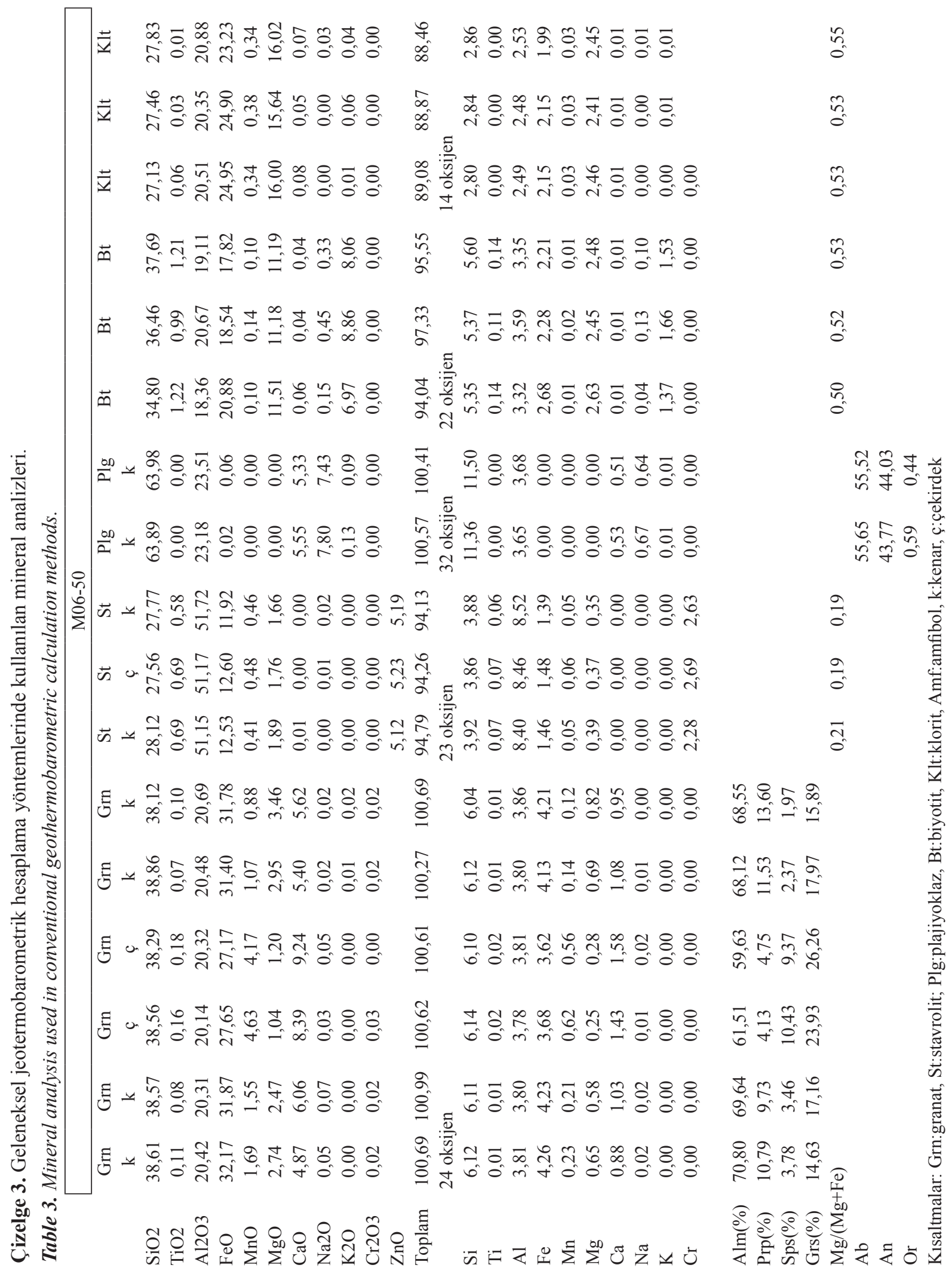




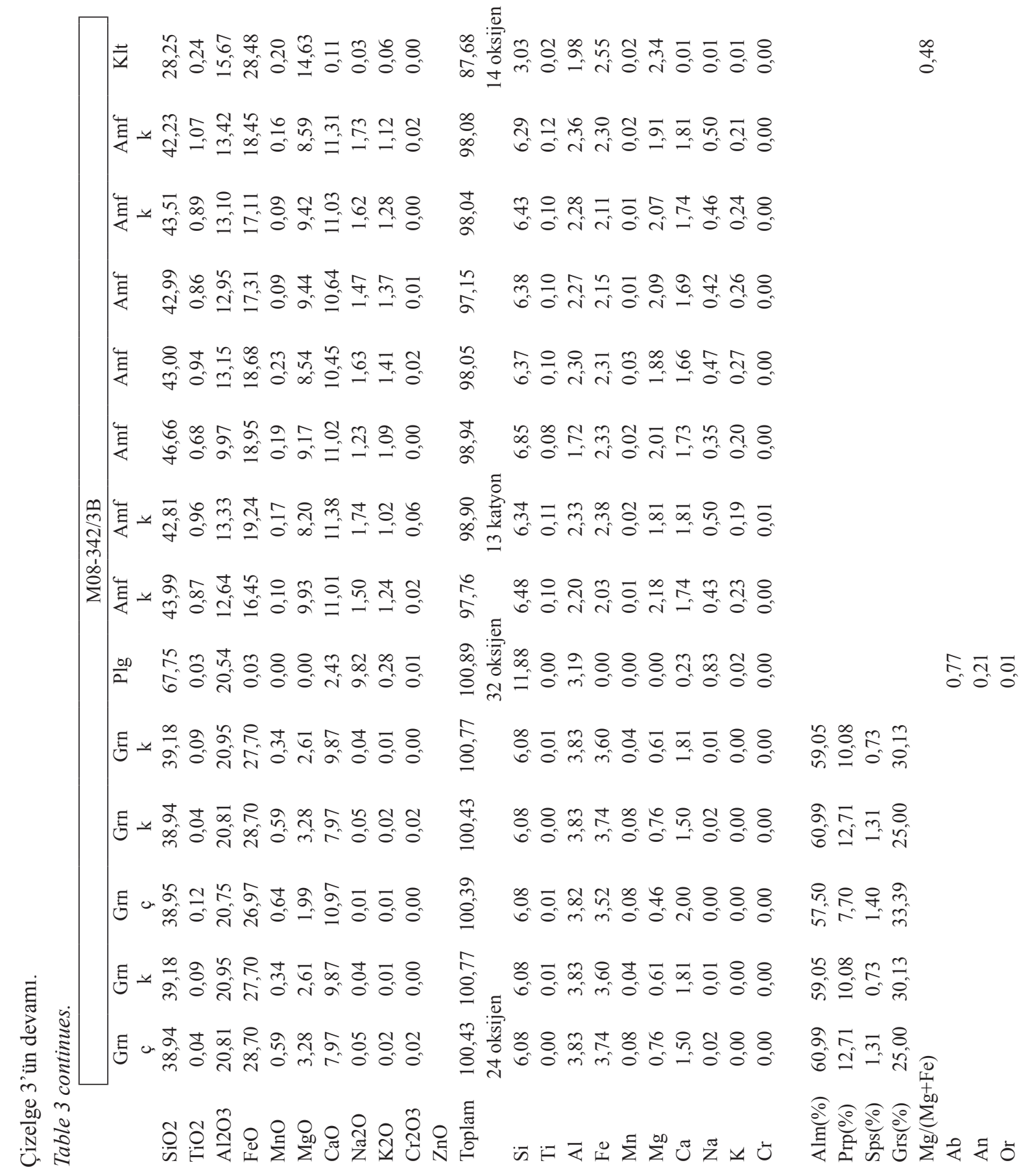


Çizelge 4. Sarıağaç şist birimini etkileyen metamorfizmaların geleneksel yöntemle elde edilmiş basınç -sıcaklık koşulları.

Table 4. Pressure-temperature conditions achieving by conventional method, of metamorphisms affecting Sarlağaç schist unit.

\begin{tabular}{|c|c|c|c|c|c|c|c|}
\hline \multirow{2}{*}{ Referans } & \multirow{2}{*}{ 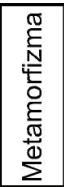 } & \multicolumn{2}{|c|}{ Sıcaklık $\left({ }^{\circ} \mathrm{C}\right)$} & \multicolumn{2}{|c|}{ Basınç (Kbar) } & \multirow{2}{*}{$\begin{array}{c}\text { Jeotermometre/ } \\
\text { jeobarometre } \\
\text { mineral }\end{array}$} & \multirow{2}{*}{$\begin{array}{c}\text { Örnek } \\
\text { No }\end{array}$} \\
\hline & & $\begin{array}{l}\text { çekirdek- } \\
\text { kenar }\end{array}$ & \begin{tabular}{|l|} 
kenar- \\
kenar
\end{tabular} & \begin{tabular}{|l|} 
çekirdek- \\
kenar
\end{tabular} & $\begin{array}{l}\text { kenar- } \\
\text { kenar }\end{array}$ & & \\
\hline Perchuk (2004) & Ms1 & 632 & 684 & & & granat-staurolit & \multirow{2}{*}{$\begin{array}{l}0 \\
10 \\
0 \\
0 \\
\stackrel{0}{\Sigma}\end{array}$} \\
\hline $\begin{array}{l}\text { Newton ve } \\
\text { Haselton (1981) }\end{array}$ & $M_{s} 1$ & & & 7.2 & 7.6 & $\begin{array}{l}\text { granat-plajioklas- } \\
\text { aluminosilikat- } \\
\text { kuvars } \\
\end{array}$ & \\
\hline $\begin{array}{l}\text { Graham ve } \\
\text { Powel (1984) }\end{array}$ & Ms 1 & $\begin{array}{c}630 \\
(K D=3.7)\end{array}$ & $\begin{array}{c}672 \\
(K D=1.8)\end{array}$ & & & granat-amfibol & \multirow{6}{*}{ 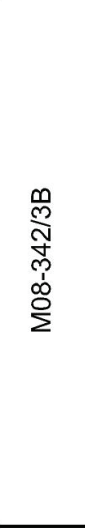 } \\
\hline $\begin{array}{l}\text { Krogh ve } \\
\text { Ravna (2000) }\end{array}$ & $\mathrm{Ms}_{\mathrm{s}} 1$ & $\begin{array}{c}641 \\
(K D=3.7) \\
\end{array}$ & $\begin{array}{c}690 \\
(K D=1.8)\end{array}$ & & & granat-amfibol & \\
\hline $\begin{array}{l}\text { Kohn ve } \\
\text { Spear (1989) } \\
\left(650^{\circ} \mathrm{C} \text { için) }\right.\end{array}$ & $M_{s} 1$ & & & 7.2 & 8.6 & $\begin{array}{l}\text { granat-amfibol- } \\
\text { plajioklas- } \\
\text { kuvars }\end{array}$ & \\
\hline $\begin{array}{l}\text { Hammarstrom ve } \\
\text { Zen (1986) }\end{array}$ & $M_{\mathbf{s}} 1$ & & & \multicolumn{2}{|c|}{$7.6 \pm 0.4$} & amfibol (Al) & \\
\hline Schmidt (1992) & $M_{\mathbf{s}} 1$ & & & \multicolumn{2}{|c|}{$8.0 \pm 0.3$} & amfibol (Al) & \\
\hline $\begin{array}{l}\text { Anderson ve } \\
\text { Smith (1995) } \\
\left(650^{\circ} \mathrm{C} \text { için) }\right.\end{array}$ & Ms 1 & & & \multicolumn{2}{|c|}{$8.1 \pm 0.4$} & amfibol (Al) & \\
\hline $\begin{array}{l}\text { Henry ve diğ. } \\
(2005)\end{array}$ & Ms2 & \multicolumn{2}{|c|}{$440-521$} & & & biyotit (Ti) & \multirow{2}{*}{$\begin{array}{l}\text { 오 } \\
0 \\
0 \\
\stackrel{0}{\Sigma}\end{array}$} \\
\hline $\begin{array}{l}\text { Bourdella ve diğ. } \\
(2013)\end{array}$ & $M_{s} 2$ & \multicolumn{2}{|c|}{$379-411$} & & & klorit & \\
\hline $\begin{array}{l}\text { Bourdella ve diğ. } \\
\text { (2013) }\end{array}$ & Ms2 & \multicolumn{2}{|c|}{$319-370$} & & & klorit & \multirow{4}{*}{ 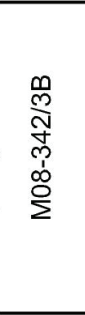 } \\
\hline $\begin{array}{l}\text { Hammarstrom ve } \\
\text { Zen (1986) }\end{array}$ & $\mathrm{Ms}_{\mathrm{s}}$ & & & \multicolumn{2}{|c|}{$4.8 \pm 0.2$} & amfibol (Al) & \\
\hline Schmidt (1992) & Ms2 & & & \multicolumn{2}{|c|}{$5.4 \pm 0.3$} & amfibol (Al) & \\
\hline $\begin{array}{l}\text { Anderson ve } \\
\text { Smith (1995) } \\
\left(650^{\circ} \mathrm{C} \text { için) }\right.\end{array}$ & Ms2 & & & \multicolumn{2}{|c|}{$5.1 \pm 0.3$} & amfibol (Al) & \\
\hline
\end{tabular}

Kısaltmalar $=\mathrm{M}_{\mathrm{s}}$ : Sarıăgaç birimini etkileyen metamorfizma, Al: alüminyum, Ti: titanyum

Şekil 6 da verilen parajenez denge diyagramında, biyotit'e ait $\mathrm{Mg \#}$ eş bileşim eğrileri $610^{\circ} \mathrm{C}$ üzeri sıcaklıklarda sıcaklık ve basınç artışı fonksiyonunda $\mathrm{Mg \#}$ değerinde artış gözlenir. $\mathrm{Bu}$ durum stavrolitle birlikte distenin ortaya çıkışını desteklemektedir.

Maksimum stavrolit $\mathrm{Mg \#} \mathrm{(0.21)} \mathrm{ve} \mathrm{biyotit}$

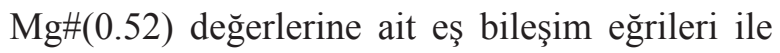
sınırlandırılmış parajenez denge çizgisinin ortak alanı (kırmızı halka) bu örneğe ait sıcaklık ve basınç değerini tanımlamaktadır $(\mathrm{P}=7,5 \pm 0,5$ kbar; $\mathrm{T}=660 \pm 10^{\circ} \mathrm{C}$ ). Stavrolite ait $\mathrm{Mg} \#=0.21$ eş bileşim eğrisi stavrolit/disten denge alanı sınırına oldukça yakındır. Aynı zamanda kayaç içerisinde \%1 civarında distenin varlığ 1 iki mineralin denge sınırına yakın bir alanda dengelendiğini göstermektedir. Elde edilen basınç - sıcaklık koşulları $\mathrm{M}_{\mathrm{S}} 1$ metamorfizması ürünü $\mathrm{S}_{\mathrm{S}} 1$ 
foliyasyonunun üst amfibolit fasiyesi koşulunda geliştiğini göstermektedir.

M09-65/1 numaral1 örneğin mineral bileşimi 'disten + biyotit + granat + plajiyoklaz + klorit + muskovit + kuvars + opak min.' den oluşmaktadır. Bu örneğe ait parajenez denge diyagramı Şekil 7' de verilmektedir. Muskovit ve biyotit-I ile temsil edilen $\mathrm{S}_{\mathrm{S}} 1$ foliyasyonu M06-50 nolu örnekten farklı olarak stavrolit içermemektedir. Stavrolitin denge alanının bitiş sınırı 'disten - granat - biyotit - plajiyoklaz - muskovit - kuvars' parajenezinin başlangıcına ve alt sıcaklık sınırına karşı1ık gelmektedir (Şekil 7). Söz konusu parajenezin minimum basınç sınırı muskovitin ortadan kaybolmasıyla belirlenir (Şekil 7). Parajenezin üst basınç sınırı ise biyotit-I'e ait $\mathrm{Mg \#} \mathrm{(0.60)} \mathrm{eş}$ bileşim eğrisi ile belirlenir. M06-50 nolu örneğe benzer şekilde $600^{\circ} \mathrm{C}$ üzeri sicaklıkta biyotitin $\mathrm{Mg \#}$ değerindeki artış basınç artışı ile ilişkilidir. Muskovitin $\mathrm{Si}^{4+}$ içeriğine bağlı olarak çizilen eş bileşim eğrileri ile şekil 7'de verilen parajenez denge alanını daha da küçültmek mümkündür. Örnekteki muskovitlerin maksimum $\mathrm{Si}^{4+}$ içeriği 3.07 dir. Muskovitin $\mathrm{Si}^{4+=} 3.07$ eş bileşim eğrisi, muskovitin alt denge sınırı, stavrolitin üst denge sınırı ve biyotit-I $\operatorname{Mg}(0.60)$ eş bileşim eğrisi arasinda kalan alan M09-65/1 nolu örneğin $\mathrm{M}_{\mathrm{S}} 1$ metamorfizmasina ait denge alanın $(\mathrm{P}=8.2 \pm 0.3$ kbar; $\mathrm{T}=670 \pm 20^{\circ} \mathrm{C}$ ) tanımlamaktadır (Şekil 7).

Sonuç olarak, şist ve içerisinde yer alan metabaziklerden oluşan yüksek dereceli temeli etkileyen $\mathrm{M}_{\mathrm{S}} 1$ metamorfizmasının basınç sıcaklık koşulları $7.7 \pm 0.7 \mathrm{kbar}$ ve $670 \pm 20^{\circ} \mathrm{C}$ olarak tahmin edilmiştir. $\mathrm{Bu}$ yüksek dereceli topluluğu üzerleyen ve onda geri dönüşümlere neden olan $\mathrm{M}_{\mathrm{s}} 2$ metamorfizmasının koşulları ise $5.1 \pm 0.3 \mathrm{kbar}$ ve $480 \pm 40^{\circ} \mathrm{C}$ olarak verilebilir.

\section{Kapıdağ Napı}

Düşük dereceli şistlerden yapılı olan Kapıdağ napında gözlenen anahtar mineraller klorit ve biyotit'dir. Kapıdağ napının basınç ve sıcaklık koşullarının belirlenmesinde mevcut anahtar mineraller kullanılarak metamorfizma koşulları $\left(\mathrm{M}_{\mathrm{K}} 1\right)$ hakkında yaklaşımda bulunulmuştur.

Kloritin ilk ortaya çıkışı kayacın metamorfizmasıyla başlar $\left(150-200^{\circ} \mathrm{C}\right)$ ve $550^{\circ} \mathrm{C}$ ye kadar duraylılığını koruyabilir (Bucher ve Grapes 2011). Barrov tipi meta-pelitlerde biyotitin ilk ortaya çıkışı Nitsch (1970) tarafından 1,4 ve7 kbar için sırasıyla $<430^{\circ} \mathrm{C}, 445 \pm 10^{\circ} \mathrm{C}$, ve $460 \pm 10^{\circ} \mathrm{C}$ olarak tanımlanmıştır. Kapıdağ napı içerisinde bulunan şistlerde granat mevcut değildir. 'granat - biyotit - klorit' parajenezi için gerekli olan minimum koşullar $525^{\circ} \mathrm{C}-3 \mathrm{kbar}$ dir (Bucher ve Grapes 2011). Granatın olmaması nedeniyle şistler için olabilecek maksimum üst sıcaklık sınırı $525^{\circ} \mathrm{C}$ olarak kabul edilebilir. Klorit ve biyotit' in bir arada bulunması $\mathrm{Fe} / \mathrm{Mg}$ oranına bağlı olarak 3.5 kbar basınç koşulunda minimum ve maksimum sicaklık aralığ $420-460^{\circ} \mathrm{C}$ dir (Bucher ve Grapes 2011). Demir bakımından zengin toplam kaya kimyasına $\left(\mathrm{X}_{\mathrm{Fe}}=0.8\right)$ sahip ortamlarda klorit biyotit birlikteliği $5 \mathrm{kbar}-540^{\circ} \mathrm{C}$ kadar duraylı kalabilmektedir. Ortalama bir pelitik kayacın XFe miktar1 0.60-0.62 dir (Bucher ve Grapes 2011). Sarıağaç birimi ile Kapıdağ napı arasındaki dokanak sünümlü tektonik dokanak tipindedir. Sarıağaç biriminin Ms2 metamorfizması Kapıdağ napı'nın $\mathrm{M}_{\mathrm{K}} 1$ 'ine karş1lık gelmektedir. Ms2'nin basınç - sıcaklık koşulları ve Kapıdağ napının mevcut indeks mineralleri göz önüne alındığında $\mathrm{M}_{\mathrm{K}} 1$ için basıncın maksimum 5 kbar olabileceği, sıcaklığın ise klorit - biyotit birlikteliği için 450 $525^{\circ} \mathrm{C}$ aralığında olması beklenmelidir.

\section{JEOKRONOLOJI}

\section{Mika ${ }^{40} \mathrm{Ar} /{ }^{39} \mathrm{Ar}$ Jeokronolojisi}

${ }^{40} \mathrm{Ar} /{ }^{39} \mathrm{Ar}$ beyaz mika jeokronolojisi Anamur bölgesinde Sarıağaç biriminde yer alan aplit (M08-357) ve metapelit (M06-54) örneklerindeki beyaz mikalara uygulanmıştır. Örneklerin mineral bileşimi Çizelge 1 de verilmektedir. Mikalar 
y1kama, eleme, binokuler mikroskop altında bireysel tanelerin toplanmasını içeren geleneksel yöntemlerle ayrılmıştır. ${ }^{40} \mathrm{Ar} /{ }^{39} \mathrm{Ar}$ jeokronolojisi, $\mathrm{CO}_{2}$ laseri kullanılarak ayrılmış olan beyaz mikaların kademeli 1sıtılması ile Potsdam Üniversitesi yer ve çevre bilimleri enstitüsünde CETAC LSX-213 cihazıyla yapılmıştır. Analizi yapılan örneklere ait ${ }^{40} \mathrm{Ar} /{ }^{39} \mathrm{Ar}$ spektrum grafikleri şekil 8 de verilmektedir. McDougall ve Harrison (1999)'a göre 2-SD hata limitleri içerisinde kalan plato yaşları, serbest kalan toplam ${ }^{39} \mathrm{Ar}$ 'un $\% 50$ 'sinden fazlası ve bireysel olarak \%5'inden fazlasını temsil eden bitişik adım serileri için hesaplanmıştır. Ar izotop analizleri sonucunda elde edilen plato yaşları serbest kalan toplam
${ }^{39}$ Ar'un \%83-94 sine karşıllk gelmektedir.

M06-54 nolu örneğe ait toplam ${ }^{39} \mathrm{Ar}$ buharlaşmasının \% 83'ne karşılık gelen 9 adet 1sıtma adımının 5 'inde $73.72 \pm 0.8$ my'lık plato yaş 1 elde edilmiştir (Şekil 8a). M08-357 nolu örnekten $75.03 \pm 2.2$ my'lık plato yaşı $\% 94$ oranında ${ }^{39} \mathrm{Ar}$ buharlaşmasını tanımlayan 6 1sıtma adımının 4'ünde bulunmuştur (Şekil 8b). Beyaz mikalara ait bloklanma sıcaklık değeri (Snee ve diğ. 1988; Knapp ve Heizler 1990) ve Sarrağaç biriminin pelitik kökenli şist örneğine ait hesaplanmış metamorfizma (Ms2) sicaklık değerleri (379$521^{\circ} \mathrm{C}$ ) göz önüne alındığında bu yaşlar Geç Kretase yaşlı zirve metamorfizma koşullarını izleyen soğuma yaşları olarak yorumlanabilir.

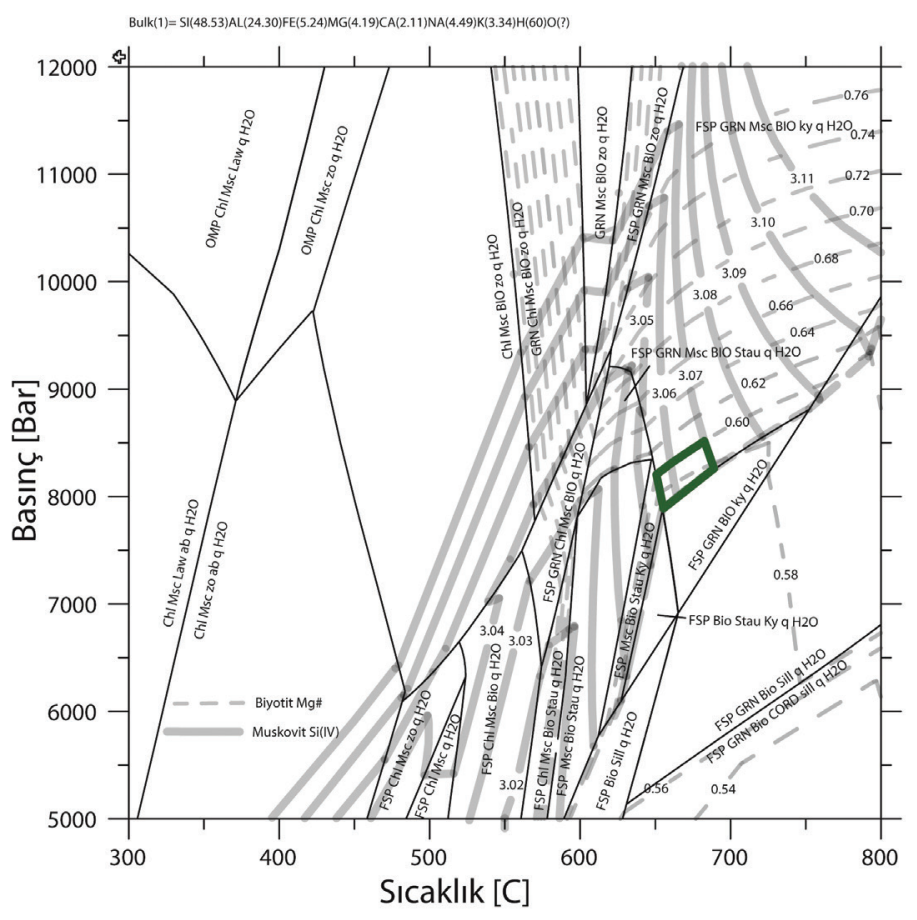

Şekil 7. M09-65/1 nolu örneğe ait parajenez denge diyagramı. Yeşil halka muskovit ve biyotit Mg\# eş bileşim eğrileriyle daraltılmış olan 'Feldispat/plajiyoklaz (FSP) - granat (GRN) Muskovit (Msc) - biyotit (BIO) - disten (KY) - kuvars (q) - H20’ parajenezinin denge alanını tanımlamaktadır. Mineral kısaltmaları şekil 6 da verilmektedir. Albit:ab.

Figure 7. Paragenesis equilibrium diagram (pseudosection) for M09-65 / 1. The green circle which is limited by muscovite and biotite Mg \# isopleths, describes the equilibrium area of the 'Feldspar / Plagioclase (FSP) - Garnet $(G R N)$ Muscovite (MSC) - Biotite (BIO) - Kyanite (KY) - Quartz (q) - H2O'paragenesis. Mineral abbreviations are given in figure 6. Albite: ab. 


\section{Zirkon U/Pb Jeokronolojisi}

Zirkon yaş analizi Çin Bilim ve Teknoloji Üniversitesi'nde (Hefei-Çin) ArF uyarılmış lazer sistemi (GeoLas Pro, 193nm wavelength) ve dört büyütmeli ICP-MS (PerkinElmer Elan DRCII) kullanılarak laser ablation ICP-MS (LA-ICPMS) yöntemiyle gerçekleştirilmiştir. Analizler 10 Hz.' lik atım oranı, 10J/cm2' lik bir 1şık enerjisi ve 44 - $32 \mu$ m'luk nokta çapı ile yapılmıştır.

Zirkon $\mathrm{U} / \mathrm{Pb}$ jeokronolojisi Sarıăaç biriminde yer alan ve $\mathrm{S}_{\mathrm{S}} 1$ foliyasyonunu keser pozisyonda bulunan metamorfik aplit'e (M08357) uygulanmıştır. Örnekten elde edilen zirkonlar ortalama 100 mikron boyutlarındadır. Zirkonlar baskın olarak renksiz, saydam, kısa-prizmatik tanelerden oluşmaktadır. Kathodoluminesans (CL) fotoğraflarında zirkonların karakteristik magmatik zonlanma (oscillatory zoning) sunan tipik magmatik zirkonlardan oluştuğu görülmektedir. Tanelerin bir kısmında, benzer şekilde tipik zonlanma sunan koyu renkli eski çekirdekler gözlenmektedir. Buçekirdekler ile etrafında gelişen büyümelerin zonlanmaları birbirine paralellik sunmaktadır (Şekil 8c). Çekirdeklerin bazılarında düzensizlikler ve yuvarlaklaşmalar gözlenmesine karşın zonlanmalar yine de paralelliğini korumaktadır. Bu durum, söz konusu tanelerdeki zonlu çekirdek olarak gözüken kısımlar ile etrafına büyüme yapan zonlu kısımların birbirini izleyen evrede büyüdüklerini göstermektedir. Bu örnekten 25 zirkon tanesi yaş tayini için kullanılmıştır. CL fotoğraflarından saptanan magmatik zirkonlardan, magmatik zonlanma sunan çekirdek kısımlardan ve bu çekirdekler etrafinda gelişmiş magmatik büyümelerden 35 analiz yapılmıştır (Şekil 8c). Düzeltilmiş izotop verileri ve yaşlar Çizelge 5 'de verilmektedir. Bu veriler konkordiya eğrisi üzerine düşürüldüğünde iki analiz hariç tümünün aynı yerde gruplandığı görülmektedir (Şekil 8d). Magmatik zirkonlar ve çekirdekler üzerine gelişen büyümeler aynı diyagram üzerine düşürüldüğünde bunlardan konkordiya yaşı olarak $548 \pm 10$ my'lık yaş elde edilmiştir. Magmatik zonlanma sunan çekirdeklerden de benzer şekilde $552 \pm$ 20 my'lık yaş elde edilmiştir. Bu yaşlardan da görüldügü magmatik büyümeler ile magmatik zonlu çekirdeklerin yaşları arasında büyük bir fark görülmemektedir. Bu nedenle verilerin tümü beraberce değerlendirilmiş örneğin magmatik kristalizasyon yaşı olarak yorumlanan $550.2 \pm 8.2$ my’lık konkordiya yaşı elde edilmiştir (Şekil 8e). 
a)

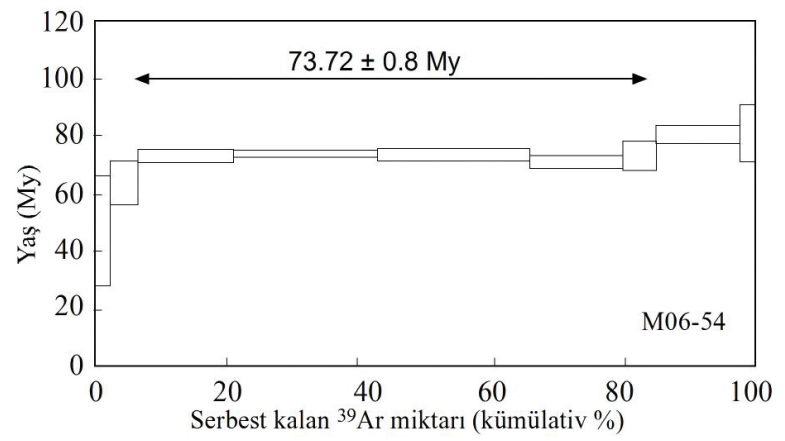

b)

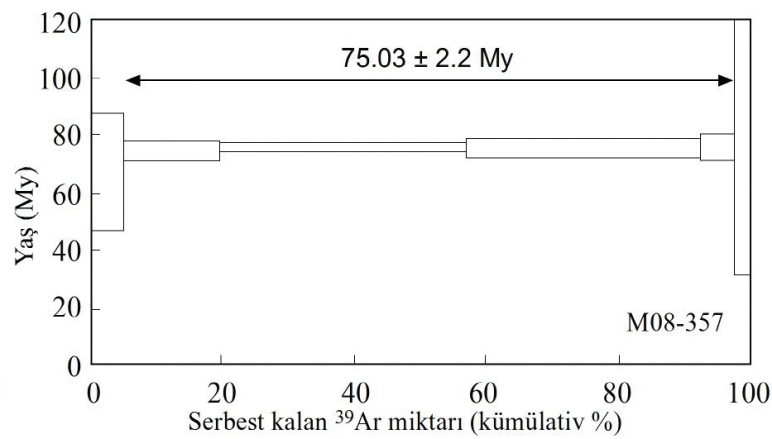

c)

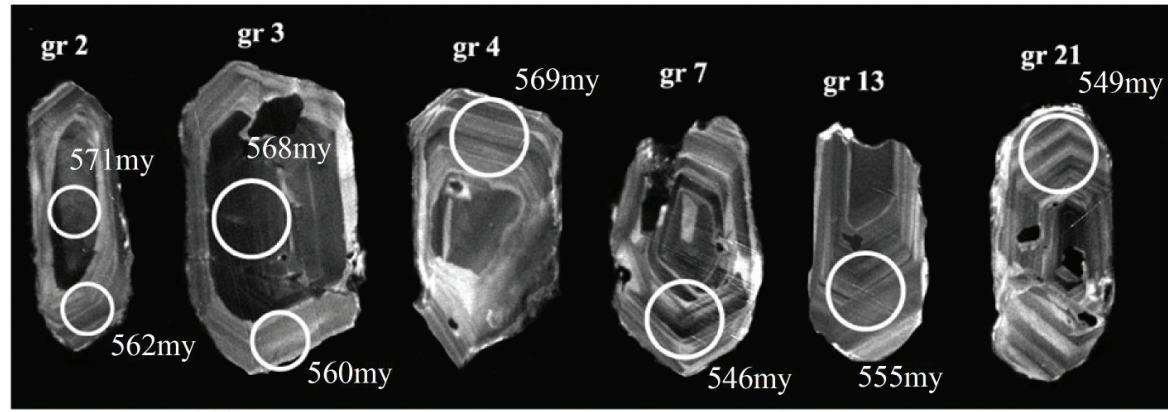

d)
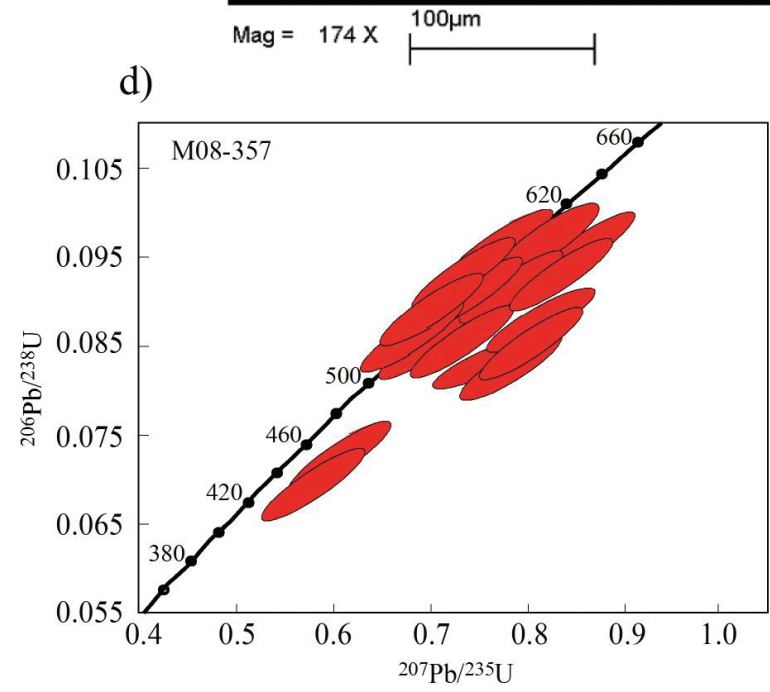

e)

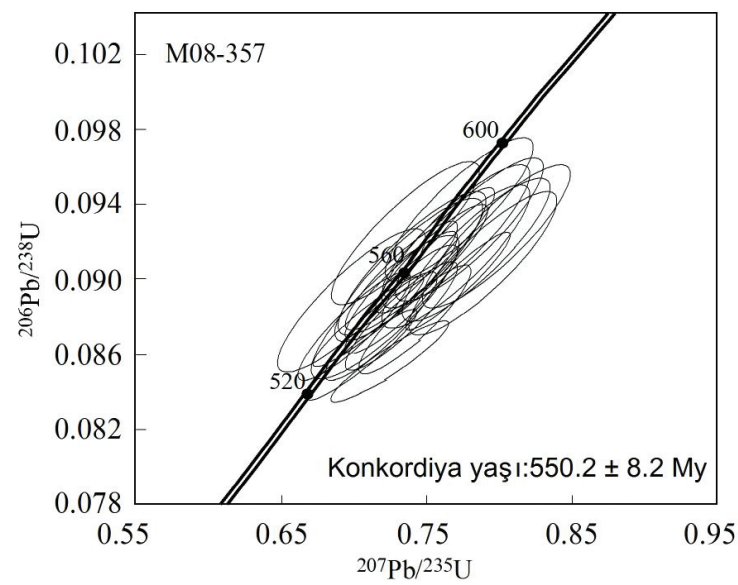

Şekil 8. a) M06-54 ve b) M08-357 nolu örneklere ait beyaz mika ${ }^{40} \mathrm{Ar} /{ }^{39} \mathrm{Ar}$ yaş spektrumu, c) M08-357 nolu örnekten seçilen zirkonlara ait kathodoluminesans fotoğrafları. Zirkonlar üzerindeki yuvarlaklar 44 ve 32 mikron çapındaki analiz yapılan noktaları göstermektedir, d) LA-ICPMS analizlerinden elde edilen tüm verilerin konkordiya diyagramı üzerindeki dağılımları, e) M08-357 nolu meta-aplit örneğinin LA-ICPMS analizleri ile elde edilen U-Pb izotop oranlarını ve kristalizasyon yaşını gösteren konkordiya diyagramı.

Figure 8. a) White mica ${ }^{40} \mathrm{Ar} /{ }^{39} \mathrm{Ar}$ age spectrum for a) M06-54 and b) M08-357, c) cathodoluminescence photographs of selected zircons from the M08-357. Circles on the zircons show points of analysis of 44 and 32 microns in diameter d) distributions on the concordia diagram of all data obtained from LA-ICPMS analyzes e) U-Pb isotope ratios obtained by LA-ICPMS analyzes of the meta-aplite sample (M08-357) and the concordia diagram showing the age of crystallization. 
Çizelge 5. Örneklerin LA-ICPMS ile elde edilen U-Pb verileri ve hesaplanan yaşlar. * Konkordiya ve ortalama yaşın hesaplanmasında kullanılan zirkon tanelerini göstermektedir. r: kenardaki yeni büyüme, c: çekirdek

Table 5. U-Pb data obtained by LA-ICPMS and calculated ages. * shows zircon grains which are used to concordia and the average age in calculations. $r$ : new growth on the rim, c: core

Düzeltilmiş İzotopik Oranlar

\section{Örnek No \\ M08-357}

gr $2 r^{*}$

gr $3 r^{*}$

gr 4*

gr 7*

gr8

gr $9 *$

gr 10

gr 11

gr 12*

gr 13*

gr $14 \mathrm{r}$

gr $21 r^{*}$

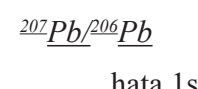

$\begin{array}{ll}0.06270 & 0.00261\end{array}$

$0.06006 \quad 0.00256$

0.05904

0.05999

0.06109

0.06856

0.06003

0.05887

0.05965

0.06235

0.06138

0.00247

$0.05999 \quad 0.00266$

$$
\underline{207} \underline{P b} \underline{235} \underline{U}
$$

hata $1 \mathrm{~s}$

$\begin{array}{ll}0.74603 & 0.03475\end{array}$

$\begin{array}{lll}0.78619 & 0.03559\end{array}$

0.76464

0.71987

0.60077

0.77686

0.78284

0.58073

0.73964

0.74198

0.79478

0.75639
0.03512

0.03219

0.02832

0.03579

0.03548

0.02731

0.03444

0.03353

0.03580

0.03449

\section{${ }^{206} \underline{\mathrm{Pb}} \stackrel{238}{\underline{U}}$}

hata $1 \mathrm{~s}$

0.09102

0.09084

0.09230

0.08846

0.07240

0.09198

0.08259

0.06997

0.09075

0.08997

0.09224

0.0888

\begin{abstract}
Düzeltilmiş Yaşlar (My)
\end{abstract}

\section{TARTIŞMA}

\section{Alanya Masifi'nin genel özellikleri}

Farklı metamorfizma koşullarında başkalaşıma uğramış bir nap yığını özelliği sunan Alanya Masifi, ilk kez Okay ve Özgül (1984) ve Okay (1989) tarafindan tanımlanan yüksek basınç metamorfizmasının varlığı ile karakterize olmaktadır. Söz konusu yüksek basınç metamorfizması Gündoğmuş bölgesinde mavişist metabazitleri (Gündoğmuş melanji), Alanya bölgesinde ise eklojit içeren glokofan şistlerle (Sugözü nap1) tanımlanmaktadır. Geç Kretase yaşlı (84-80 My) bu metamorfizma, Alanya-Bitlis okyanusunun bir okyanus içi dalımla kapanmaya başlaması ve Alanya-Bitlis Mikrokıtası olarak tanımlanan kıtasal parçacığın kuzeye doğru Anatolid-Torid platformu altına yitimi ile ilişkilendirilmektedir (Çetinkaplan ve diğ., 2016).

Alanya Masifi'ndeki naplı içyapı ve polimetamorfik evrim Alanya kuzeydoğusunda açıkça gözlenmektedir. Masif'in en iyi çalışılmış bu bölgesinde (Okay ve Özgül, 1984, Okay 1989, Bozkaya 2001, Bozkaya ve Yalçın, 2004; Çetinkaplan ve diğ 2016) istif alttan üste doğru; i) Mahmutlar nap topluluğu (alt nap), ii)Sugözü napı (orta nap) ve en üst konumda bulunan iii)Yumrudağ nap topluluğundan (üst nap) oluşmaktadır. Mahmutlar ve Yumrudağ nap topluklarını Barrov tipi yeşilşist, Sugözü nap1 ise eklojit - mavişist fasiyesi koşulunda metamorfizmaya uğramıştır (Okay 1989; Çetinkaplan ve diğ, 2016). Bu napların birbirleri ile olan dokanakları yeşilşist fasiyesi koşullarında gelişmiş sünümlü bir deformasyonu yansitmaktadır. Bozkaya (2001) ve Bozkaya ve Yalçın (2004) tarafından yapılan fillosilikat mineralojisine dayanan çalışmalarda Mahmutlar napının orta basınç, Sugözü napının da yüksek basınç metamorfizmasını izleyen Barrov tipi orta basınç metamorfizmasından etkilendiğini söylemektedir. Buna karşın Yumrudağ napının ise saatin tersi yönünde düşük dereceli metamorfizmaya maruz kaldığını 
savunmaktadır. Mahmutlar nap topluluğu Alt Triyas yaşlı şist-mermer ardalanması ile başlar ve olasılı İnfrakambriyen yaşlı kahverengi dolomit, mermer, kuvarsit ve şist ardalanmasından oluşan bir topluluk tarafından tektonik dokanakla üzerlenir. Sugözü napı orta naptır ve kılavuz düzey niteliğindedir. Bu nap baskın olarak granatfengit şist ve granat-glokofan-fengit şistten oluşur. Metakırıntılılar içerisinde mercek şeklinde gözlenen eklojit, glokofanit ve amfibolitten oluşan metabazitler bu napı tanımlayıcı kayaç türleridir (Okay 1989). Yumrudağ nap topluluğu iki tektonik dilimden oluşmaktadır. Alt dilim, olasılı İnfrakambriyen yaşlı kahverengi dolomit, mermer, kuvarsit ve şist ardalanmasından oluşan kayaç topluluğu ile başlamaktadır. Bu topluluğun üzerine uyumlu olarak Toros birliklerinin tipik Kambriyen-Ordovisiyen birimleri olan Hüdai, Çaltepe ve Seydişehir formasyonlarının metamorfik eşleniklerinden oluşan ve kendi içerisinde düzenli ve kesiksiz bir istif sunan topluluk gelmektedir (Çetinkaplan ve diğ, 2016). Bunun üzerine tektonik bir dokanakla ÜstPermiyen yaşlı homojen ve kalın mermerler gelir. Üst nap ise Alt Triyas yaşlı şist - mermer ardalanması ve onu uyumlu olarak üzerleyen dolomitlerden oluşmaktadır Bölgede yapılan önceki çalışmalarda Alanya birliğine ait metamorfik kayaçların Permiyen - Triyas yaş aralığında olduğu ifade edilmiştir (Özgül 1976; Okay ve Özgül, 1984). Bozkaya (2001) ve Bozkaya ve Yalçın (2004) ise Alanya'nın güney doğusunda yer alan Demirtaş bölgesinde bulunan Mahmutlar napının Permiyen öncesi - Permiyen ve Yumrudağ napının Permiyen Öncesi (?) -Permiyen - Triyas yaşında olduğunu belirtmektedir.

\section{Anamur bölgesindeki istifin Alanya Masifi içerisindeki yeri ve Toros Birlikleri ve Gondwana ile korelasyonu}

Anamur bölgesi, Alanya Masifinnin diğer bölgeleri ile karşılaştırıldığında oldukça sade bir tektonostratigrafi sunmaktadır. İstif, damar karakterinde bazik ve asidik magmatik kayaçlar tarafından kesilmiş ve üst amfibolit fasiyesi koşullarını yansıtan metakırıntılılarla tanımlanan paraotokton konumdaki Sarıăgaç birimi ile başlamaktadır. Yüksek dereceli bu kayalar, yine Barrov türü orta basınç metamorfizmasının yeşilşist fasiyesinde başkalaşıma uğramış düzenli ve kalın bir istifle (Kapıdağ nap1) tektonik olarak üzerlenir. Bu istif tabanda dolomit, mermer, muskovit- kuvars şist ve klorit şist ardalanmasından oluşan topluluk ile başlamakta ve üzerine stratigrafik bir dokanakla kalın ve homojen bir muskovit-kuvars şist birimi gelmektedir. Kuvarsitler, çörtlü dolomitlerle başlayan ve pembemsi-kırmızımsı yama ve yumrular içeren, yaklaşık 160 m kalınlığında bir mermer düzeyi ile üzerlenmektedir. Mermerler, alt kesimleri ince pembe yumrulu mermer ara düzey ve mercekleri içeren homojen klorit şistlere geçmektedir.

Türkiye'nin genel tektonik sinıflamasında (Ketin 1966; Okay ve Tüysüz 1999, Candan ve diğ., 2016) İzmir-Ankara-Erzincan Kenet kuşağının güney kesimi, birbirilerinden BitlisZagros kenet zonu ile ayrilan; i) Anatolid Toridler ve ii)Arap Levhası olmak üzere iki ana ünite ile tanımlanmaktadır. Bu iki ünitenin Erken Triyas'a kadar Gondwana'nın kuzey pasif kıta kenarına bağlı kaldığı ve Neotetis Okyanusu'nun güney kolunun Erken Triyas'ta açılması ile AnatolidTorid Bloğu'nun Gondwana'dan ayrılarak kuzeye sürüklendiği günümüzde yaygın olarak kabul edilmektedir (Şengör ve diğ., 1984, Şengör ve Yılmaz 1981). Dolayısıyla, birçok çalışmada da açıkça ortaya konduğu gibi (Yalçın 1980; Göncüoğlu ve Kozlu 2000; Ghienne ve diğ., 2010; Gürsu ve diğ., 2015) Arap levhas1 ile AnatolidToridler ortak bir Paleozoyik istif sunmaktadır.

Günümüzde tektonik üniteler olarak bulunan Toridler ve onlarin metamorfik eşlenikleri olan Anatolidler (Okay ve diğ 2001, Candan ve diğ., 2005) ilksel tortul fasiyes özelliklerine göre paleocoğrafik olarak yeniden konumlandırılabilmekte ve buna dayalı olarak çok 
sayıda tektonik üniteye ayrılmaktadır (Özgül 1976, 1984, 1997). Bu ünitelerden Geyikdağ1 ve Antalya birlikleri alt Paleozoyik istifleri içermektedir (Özgül ve diğ., 1972, Özgül 1976, Şenel ve diğ., 1996; Dean ve diğ., 1999; Özgül ve Kozlu 2002; Göncüoğlu ve diğ., 2004). Hadim/Konya (Özgül ve Gedik 1973; Turan 2000), Tufanbeyli/Feke (Özgül ve diğ 1972, Monod ve diğ., 2003), Seydişehir (Dean 2005), Sultandağları (Güngör 2013) ve Silifke / Orta Toroslar (Kozlu ve diğ., 2002) de yüzeyleyen bu istifler ortak stratigrafik özellikler sunmakta (Gürsu ve diğ., 2003 Göncüoğlu ve Kozlu 2000) ve tabanda bazik volkanik, kumtaş1, kireçtaş1 ve sleyt ardalanmasından yapıl1, olasılı İnfrakambriyen - Erken Kambriyen (Kozlu ve Göncüoğlu 1996, Göncüoğlu ve Kozlu 2000; Özgül ve Kozlu 2002) olarak tanımlanan toplulukla (Emirgazi Formasyonu) başlamaktadır. $\mathrm{Bu}$ topluluk, stratigrafik bir dokanakla, genelde Hüdai Formasyonu olarak adlandirılan Erken Kambriyen yaşlı (Ghienne ve diğ 2010) kalın homojen kuvarsitlerle üzerlenmektedir. Kuvarsitler uyumlu olarak çörtlü dolomitlerle başlayan ve kırmızı renkli yumrulu kireçtaşlarına (Çaltepe Formasyonu; Özgül ve Gedik 1973; Dean 2005) geçen bir karbonat istifi ile üzerlenmektedir. İstifteki ilk fosilli düzeyleri oluşturan ve trilobit fosilleri ile tanımlanan bu karbonatlar için AltOrta Kambriyen yaşı önerilmektedir (Özgül ve Gedik 1973; Özgül ve Kozlu 2002). Karbonatlar geçişli bir dokanakla Seydişehir Formasyonu olarak adlandırılan (Monod ve diğ ., 2003), Kambro-ordovisiyen yaşlı homojen şeylerle üzerlenmektedir. Arap Levhası'na ait erken Paleozoyik istif Hakkari, Mardin ve Amanos Dağları çevresinde yüzeylemektedir (Demirkol 1988, Yalçın 1980; Dean 2006; Ghienne ve diğ 2010). Hakkari bölgesinde istif tabanda kuvarsitik kumtaşları ile tanımlanan, Erken Kambriyen yaşlı Zabuk Formasyonu ile başlamakta (Yalçın 1980; Ghienne ve diğ 2010) ve trilobit içeren, orta Kambriyen yaşlı kırmızımsı yumrulu kireçtaşları (Koruk Formasyonu) ile devam etmektedir (Dean
2006; Ghienne ve diğ 2010). K1lavuz düzey niteliğindeki karbonatlar uyumlu dokanakla Kambro-ordovisiyen yaşlı homojen şeyllere geçerler (Sosink Formasyonu). Mardin bölgesinde, Geç Neoproterozoik yaşlı volkanikler yer almakta (Gürsu ve diğ., 2015) ve bunlar Hakkari'dekine benzer istifle üzerlenmektedir (Ghienne ve diğ., 2010).

Görüleceği gibi çalışma alanındaki Kapıdağ Nap1, fosil bulunamamış olmasına karşın gerek Arap Levhası gerekse Toridler'in Geyikdağı Birliği'nin İnfrakambriyen-Ordovisiyen istifi ile kaya türü ve stratigrafik ilişkiler açısından belirgin benzerlikler sunmaktadır. Buna dayanarak Barrov türü orta basınç koşullarında başkalaşıma uğramış Kapıdağ nap1 istifinin Gondwana'nın kuzey kenarında çökelmiş İnfrakambriyen-Ordovisiyen yaşlı pasif kıta kenarı çökellerinin metamorfik eşlenikleri olduğu söylenebilir. Ayrıca bu istif, yukarıda tanımlanan Alanya kuzeydoğusundaki düşük dereceli istifle (Yumrudağ napı; Okay 1989, Çetinkaplan ve diğ., 2016) gerek ilksel stratigrafi / kaya türü gerekse metamorfizma koşulları açısından karşılaştırılabilir özellikler sunmaktadır. Çalışma alanındaki metamorfik kayaçlar Işık ve Tekeli (1995) tarafından Alanya Masifi metamorfikleri olarak adlandırılmıştır. Bozkaya (2001) ve Bozkaya ve Yalçın (2004) ise sözkonusu alandaki metamorfik kayaçları Mahmutlar napının yüksek dereceli kesimi olarak yorumlamıştır.

Çalışma alanında paraotokton konumda bulunan Sarıăaç birimi metamorfizma koşulu ve kayaç topluluğu bakımından Alanya Masifinin başka hiçbir yerinde gözlenmemektedir. Bu durum, birimin Alanya Masifine ile olan ilişkisini tartışı1ır hale getirmektedir. Sarıăaç birimi içerisinde yer alan şistlerde ilksel kırıntılı tortulların sedimantasyon yaşı ve provenansı üzerine gerçekleştirilmiş bir çalışma bulunmamaktadır. Önceki bölümlerde de belirtildiği gibi bu şistler içerisinde bölgesel foliyasyonunu kesen damar karakterli asidik kayaçlara (aplit, pegmatit vb) yaygın olarak rastlanmaktadır. $\mathrm{Bu}$ damar 
kayalarından bir tanesinden elde edilen zirkonlar LA-ICP-MS U/Pb yöntemiyle yaşlandırılmıştır. Elde edilen 550 My yaş, zirkonların tipik magmatik zonlanma desenlerine bak1larak ilksel kayacın magmatik kristalizasyon yaşı olarak yorumlanmıştır. Eldeki bu yaş verisi ve damarların çevre kayayı belirgin olarak kesiyor olmaları, çevre kayayı oluşturan yüksek dereceli şistlerin ilksel kırıntılılarının sedimantasyon yaşının 550 My dan yaşl1, yani Prekambriyen olduğunu göstermektedir.

Arap levhasındayaklaşık 550 My lık magmatik aktivite sadece Mardin/ Derik bölgesinde gözlenmektedir. Erken Kambriyen yaşı 1ı Telbesmi Formasyonunun altında yer alan bu kayalar andezit-riyolit bileşiminde volkanik kayalardan oluşmaktadır. Çok düşük dereceli metamorfizma gösteren bu volkanik kayalar zirkon U/Pb yöntemiyle 581-559 My olarak yaşlandırılmıştır (Gürsu ve diğ., 2015). Toros birimlerinde ise benzer yaşlarda magmatizmanın varlığı Afyon/ Sand1klı (Kröner ve Şengör 1990; Erdoğan ve diğ., 2004; Gürsu ve diğ., 2004; Gürsu ve Göncüoğlu 2005) ve Isparta/Karacahisar (Abbo ve diğ. 2015) bölgelerinde belgelenmiştir. Sandıklı bölgesindeki asidik magmatiklerden 543 My (Kröner ve Şengör 1990) Karacahisar bölgesinde Bozburun şistleri içerisinde yer alan dayklardan ise $544 \mathrm{My} \mathrm{U}-\mathrm{Pb}$ yaşı elde edilmiştir (Abbo ve diğ. 2015). Ortak bir özellik olarak gerek Arap Levhası gerekse Toros birliklerinin tabanlarında gözlenen ve Kadomiyen Orojenezi ile ilişkilendirilen (Gürsu ve diğ., 2004; Gürsu ve Göncüoğlu 2005) benzer yaştaki bu magmatik aktivitenin çevre kayaçları klorit ve muskovitin varlığı ile tanımlanan çok düşük dereceli metamorfizma özelliği göstermektedir (Bozkaya ve diğ., 2006).

Benzer yaştaki (Geç Neoproterozoyik) magmatik aktivite Anatolidler ve Güneydoğu Anadolu'daki metamorfik masiflerde de yaygın olarak belgelenmiştir. Menderes Masifi'nde 520584 My arasında değişen (Candan ve diğ., 2011a, Koralay 2015; Koralay ve diğ., 2011) asidik / bazik magmatizmaya yüksek dereceli ve polimetamorfik (Hetzel ve Reischmann 1996; Loos ve Reischmann 1999; Candan ve diğ., 2011b, 2016) bir temel eşlik etmektedir. Söz konusu temelin metamorfikmagmatik evrimi Gondwana'nın Prekambriyen sonunda bir süper kıtaya dönüşmesi (Collins 2006; Johnsen ve diğ., 2011; Fritz ve di ̆ 2013 ) ile ilişkili orojenik süreçlerle ilişkilendirilmektedir (Koralay 2015, Candan ve diğ., 2011c, 2016). Toroslar'a ait Paleozoyik seriler tarafindan uyumsuz olarak örtülen bu temel, Alpin orojeneziyle Eosen'de bir kez daha orta basınç koşullarında metamorfizmaya uğramıştır. Benzer şekilde Bitlis (531-545 My, Ustaömer ve diğ., 2009) ve Pütürge (544-551 My; Beyarslan ve diğ., 2016) masiflerindeki yüksek dereceli Prekambriyen temel içerisindeki metagranitlerden de Prekambriyen yaşlar elde edilmiştir. Bu masiflerde de Menderes Masifi'ne benzer şekilde Prekambriyen temel ile onu uyumsuz olarak üzerleyen (Göncüoğlu ve Turhan 1997; Erdoğan ve Dora 1983) Paleozoik örtü arasında metamorfizma derecesi açısından sıçrama mevcuttur. $\mathrm{Bu}$ durum, son Alpin üzerlemesinin yanı sira temelin, Prekambriyen'de olas1lıkla Gondwana'nın toparlanma süreci ile ilişkili ayrı bir yüksek dereceli metamorfik evrimi olduğunu açıkça ortaya koymaktadır.

Sonuç olarak, Gondwana'nın bütünleşme süreçleri, Geç-Neoproterozoyik-Erken Paleozoyik paleocografyas1, Anatolid ve Toridler'in Prekambriyen temellerinin tektono-metamorfik evrimleri ve Arap Levhas1-Toridler'in erken Paleozoyik istiflerinin çökelme ortamları birlikte değerlendirildiğinde Anamur bölgesindeki yüksek dereceli metamorfikler Gondwana süper kıtasının oluşma süreçlerini tanımlayan orojenezlerle ilişkili kristalen bir temel olarak yorumlanabilir. Anamur bölgesinde gözlenen Erken Paleozoyik kayaçları orijinalde bu temel üzerine uyumsuz bir dokanakla çökelmiş olmalıdır. Günümüzde bu dokanak ilişkisi Geç Kretase yitimiyle ilksel özelliğini kaybetmiş olup günümüzde bir bindirme fayı ile tanımlanmaktadır. 
Anamur bölgesindeki birimlerin Geç Kretase yüksek basınç metamorfizması ile olan iliş kileri

Yukarıda da kısaca açıklandığı gibi Alanya Masifi Geç Kretase yaşlı yüksek basınç metamorfizmasının varlığı ile tanımlanmaktadır (Okay 1989, Çetinkaplan ve diğ., 2016). Fakat bu yüksek basınç metamorfizmasının, yitim, kıtasal çarpışma ve kabuk kalınlaşması sürecinde tektonik dilimlerin farklı derinliklere gömülmeleri nedeniyle her tektonik dilimde gelişmediği petrolojik ve jeokronolojik verilerle ortaya konmuştur (Çetinkaplan ve diğ., 2016). Bu durum, Alanya Masifi'nde her tektonik dilimin, olasılı yüksek basınç metamorfizması açısından ayrı ayrı olarak ele alınıp incelenme zorunluluğunu ortaya çıkarmaktadır.

Anamur bölgesindeki Sarıăaç Birimi, pelitik kökenli çevre kaya içine sokulum bazik ve asidik magmatiklerden oluşmaktadır. Bilindiği gibi özellikle bazik kökenli magmatik kayaçlar yüksek basınç metamorfizması etkilerini en iyi yansıtan kayaç grubudur. Pelitik kökenli yüksek basınç kayaları ise orta basınç üzerlemesi sırasında çok yaygın bir şekilde geri dönüşüme uğrayabilmektedir (Heinrich 1982, Aoya 2001, Tsujimori ve Liou 2007). Bazik kayaçlar mavişist fasiyesi koşullarında glokofan - epidot/lavsonit (Maruyama 1986, Tsujimori ve Ernst 2014), eklojit fasiyesi koşullarında ise omfasit, granat ve rutilin (Carswell 1990, Möller 1998, Aoya ve diğ. 2003) varlığı ile tanımlanır. Çalışma alanındaki bazikler makaslama zonlarının geçtiği şiddetli deformasyona uğramış alanlarda tamamen rekristalizasyona uğrayıp amfibolitlere dönüşmüşlerdir. Buna karşın makaslama zonları arasındaki düşük gerilimli alanlarda baziklere ait ilksel magmatik doku büyük oranda korunmuştur. Statik kristalizasyonun gerçekleştiği bu deformasyondan korunmuş alanlarda ilksel granoblastik doku granat, hornblend ve plajiyoklazdan oluşan metamorfik mineral topluluğuna dönüşmüştür. Mikroprob çalışmaları bu amfibolün baskın olarak yüksek sicaklık amfibolü olan tshermakitik-hornblend bileşiminde olduğunu göstermektedir. Makaslama zonlarının geçtiği alanlardaki amfiboller ise hornblend bileşiminde olup bu minerale klorit, granat zoisit/ epidot ve plajiyoklaz eşlik etmektedir. Gerek statik gerekse dinamik olarak kristalleşmiş alanlarda gerçekleştirilen dokusal analizler, kayadaki mevcut olan Ca-amfibollerin önceki bir yüksek basınç metamorfizmasına ait Na-amfibollerden geri dönüşüm yoluyla oluştuğuna ilişkin bir dokusal verinin bulunmadığını göstermiştir. Ayrıca yüksek basınç metamorfizmasında plajiyoklazın duraylılık alanı aşılmakta ve bu mineral Na-piroksen ve epidot/zoisit tarafindan replase edilmektedir (Pognante 1985, Lang and Gilotti 2001). Bölgedeki baziklerde bu tür plajiyoklaz dönüşümüne ilişkin hiçbir dokusal veri saptanamamıştır. Asidik magmatik kayaçlar yüksek basınç metamorfizmasıyla jadeit /omfasit, koezit ve fengit'den oluşan mukronit adı verilen kayaçlara dönüşmektedir (Compagnoni and Maffeo 1973, Harlow 1994). Ancak genel olarak bazik magmatik kayaçlar kadar yüksek basınç metamorfizmasını iyi yansıtamamaktadırlar. Bunu nedeni, minerallerin yarı kararlı devamlılıklarını yüksek basınç metamorfizması süresince sürdürebilmeleri veya yüzeylenme sırasında magmatik kayaçlara oranla daha düşük dayanıma sahip olmaları nedeniyle makaslama zonları boyunca daha fazla su gelimine maruz kalmaları olarak gösterilmektedir (Proyer 2003). Türkiye'de Tavşanlı zonunda (Okay 1997) ve dünyanın çeşitli lokalitelerinde (Sesia zonuBatı Alpler, Doğu Çin, Seward Yarımadas1Alaska: Forbes ve diğ.1984, Patrik ve Evans 1989) yüksek basınç metamorfizmasına uğramış asidik magmatik kayaçlar bulunmaktadır. Bunların genel bileşimi jadeit, koezit/kuvars, disten, zoisit ve K-feldispat'dan oluşmaktadır. Anamur bölgesindeki asit bileşimli magmatik kayalar pegmatit ve aplitlerle temsil edilmektedir. Granoblastik dokunun gözlendiği bu kayaçların genel mineral bileşimi plajiyoklaz, kuvars 
ve muskovit olup önceki bir yüksek basınç metamorfizmasını tanımlayabilecek dokusal ve mineralojik verilerden yoksundur.

Anamur bölgesinde asidik ve bazik metamagmatiklerin çevre kayaları pelitik kökenli şistlerdir. Mikaca zengin bu tip kayaçlarda yüksek basınç metamorfizmasına ait verilerin silinmesi baziklere oranla çok daha şiddetli gerçekleşmektedir (Heinrich 1982, Aoya 2001, Tsujimori ve Liou 2007). Bunun nedeni olarak pelitik metamorfitlerin yüzeylenmesi sırasında basınç düşmesine bağlı olarak meydan gelen genleşmenin kayaçları çatlatması ve bu çatlaklar boyunca kayaç içerisine nüfuz eden akışkan fazın pelitik kayaçlarda hızlı geri dönüşüme neden olması gösterilmektedir (Rubie 1986; Masonne 2012). Akışkan fazın etkilemediği kesimlerde yüksek basınç metamorfizması fazları olarak glokofan, jadeit, Mg-kloritoid ve fengit gibi mineraller gözlenebilmektedir (Sisson 1997; Okay 2002). Pelitik kayaçlarda geri dönüşüm, glokofanın Ca-amfibol tarafından tüketilmesi (Kryza ve diğ., 1990), Mg-kloritoid'in Fe içeriğinin artması, fengit de çekirdekten kenara doğru Si içeriğinde meydana gelen azalış gibi basınç düşmesini ifade eden verilerle tanımlanır. Sarıăaç şistinde yapılan petrografik gözlem ve mikroprob analizlerinde bu tür verilerden hiçbiri saptanmamıştır. Ancak bir adet metapelit örneğinde beyaz mikaların Si içeriği 3.50 ye kadar ulaşmaktadır. Beyaz mikanın yüksek Si içeriği bazı araştırılar tarafından yüksek basınç verisi olarak kabul edilmektedir. Fakat Massonne ve Schreyer (1989) yüksek Si içerikli mikanın K-feldispat olmaksızın yüksek basınç metamorfizmasını temsil edemeyeceğini belirtmektedir. Sözkonusu örnekte (M06-54) K-feldispatın bulunmaması beyaz mikalardaki yüksek Si içeriğinin yüksek basınç metamorfizmasından kaynaklanma olasılığını zayıflatmaktadır. Sarıăaç birimini oluşturan metapelitler sillimanit, disten, stavrolit, granat ve biyotit den oluşan mineral toplulukları içermektedir. $\mathrm{Bu}$ topluluklar söz konusu kayaçların Barrov türü orta basınç metamorfizması koşullarında metamorfizmaya uğradığını göstermektedir. Sillimanitin varlığı koşulların üst amfibolit fasiyesine kadar yükseldiğini tanımlamaktadır.

Sonuç olarak Sarıăaç birimini oluşturan litolojilerin mineral parajenezleri orta basınç metamorfizmasını tanımlamaktadır. Bu litolojilerin hiçbirinde önceki bir yüksek basıncı tanımlayan mineralojik ve dokusal veri bulunmamaktadır. Benzer şekilde İnfrakambriyen-Erken Paleozoik yaşlı ve tümüyle pelitik kayaçlardan oluşan Kapıdağ nap1, klorit ve nadir olarak gözlenen biyotitin varlığ 1 ile tanımlanan Barrov türü orta basınç metamorfizmasının düşük yeşilşist fasiyesi koşullarında metamorfizmaya uğramıştır. $\mathrm{Bu}$ toplulukta da yukarıda tanımlanan olasılı bir yüksek basınç metamorfizmasını tanımlayacak hiçbir kalıntı doku ve mineral saptanamamıştır. $\mathrm{Bu}$ kayaçların, Alanya bölgesindeki eşlenikleri olan Yumrudağ nap topluluğunun Kapıdağ napında olduğu gibi (Çetinkaplan ve diğ., 2016) Geç Kretase'deki yitim ve izleyen kıtasal çarpışma sürecinde maksimum $23 \mathrm{~km}$ derinliğe gömüldüğü düşünülmektedir.

\section{Anamur bölgesindeki birimlerin metamorfizma yaşları}

Önceki bölümlerde detaylı tanımlandığı gibi Anamur bölgesinde paraotokton konumdaki Sarıağaç birimi yüksek dereceli şistler ve onların bölgesel foliyasyonlarını çoğu yerde kesen, masif yapıda aplitik damar kayaçlarından oluşmaktadır. Buna karşın bazı bölgelerdeki damarlarda, ufak mika yönelişleri ile tanımlanan zayıf bir foliyasyonun varlığı gözlenmiştir. Arazi verisi ve dokusal özelliklere dayalı olarak çizilmiş, şematik damar - çevre kaya ilişkisi Şekil 3'de gösterilmektedir. Yaygın kesme ilişkileri, yüksek dereceli metamorfizmanın aplitlerin yerleşiminden önce gerçekleştiğinin açık bir verisidir. $\mathrm{Bu}$ kapsamda net arazi ilişkisi gözlenen bir bölgede 
yönlenmesiz beyaz mika içeren bir aplit örneğinden (örnek no:M08-357) ayıklanan zirkonlar U/Pb yöntemiyle, ayni örnekteki mikalar da $\mathrm{Ar} / \mathrm{Ar}$ yöntemiyle yaşlandırılmıştır. Ayni yüzlek üzerinde çevre kayanın foliyasyon düzlemini tanımlayan ve aplit tarafından kesilen bir şist örneğinden (Örnek no:M06-54) ayıklanan beyaz mikalar da yine Ar/ Ar yöntemi ile yaşlandırılmıştır. Daha önceki bölümlerde tanımlandığı gibi zirkonlardan, aplitin kristalizasyon yaşı olarak yorumlanan $550 \mathrm{My}$ yaş elde edilmiştir. Fakat gerek aplitteki yönlenmesiz mikalar gerekse şistteki foliyasyonu tanımlayan beyaz mikalar birbirileriyle uyum gösterecek şekilde sırasıyla 75 My ve 73 My (Kampaniyen) yaşlar vermiştir. Birbirileriyle çelişen bu yaş verileri yüksek dereceli metamorfizmanın yaşını (Prekambriyen veya Geç Kretase) tartışılır hale getirmiştir.

Özellikle çoklu metamorfizmaya uğramış alanlarda bu çelişkili gözüken durumlara yaygın bir şekilde değinilmektedir. Örneğin Menderes Masifi'nin Prekambriyen temelindeki kalıntı granulit, eklojit ve üst amfibolit fasiyesi metamorfizmaları zirkon $\mathrm{U} / \mathrm{Pb}$ yaşlarına göre sirasiyla 584 My (Koralay 2015), 535 My (Candan vediğ.,2016) ve 551 My(Hetzelvediğ. 1998) olarak saptanmıştır. Bu metamorfizmalar, Gondwana'nın Geç Neoproterozoyik-Erken Kambriyen bütünleşme süreçleri ile ilişkilendirilmektedir (Candan ve diğ., 2011b, 2016). Bu petrolojik jeokronolojik verilere karşın söz konusu temeldeki mikalar, Alpin üzerlemesi nedeniyle yaklaşık 3050 My (Geç Eosen-Oligosen) arasında değişen yaşlar vermektedir (Satır ve Friedrichsen 1986; Hetzel ve Reischmann 1996; Bozkurt ve Satır 2000). Bu durum, Geç Neoproterozoyik temel içerisindeki mikaların Alpin üzerlemesi sırasında resetlenmesi ile açıklanmaktadır.

Sarıăgaç birimi içerisindeki yüksek dereceli şistlerden yapılan dokusal analizler kayaçlarda birden fazla deformasyonun ve onlarla bağlantılı foliyasyon gelişiminin varlığını ortaya koymuştur. Bazı örneklerde yüksek dereceli metamorfizmayı tanımlayan disten ve stavrolit gibi fazlar ve onlara eşlik eden muskovitlerin oluşturduğu foliyasyonun, biyotit ve muskovitle tanımlanan ikinci bir foliyasyon ile kesildiği gözlenmiştir (Şekil 3). Bu ikincil mineral topluluğu üzerleyen metamorfizmanın en azından yeşilşist fasiyesinin biyotit zonu koşullarında geliştiğini göstermektedir. Beyaz mikaların $\mathrm{Ar} / \mathrm{Ar}$ izotop sistemlerinin bloklanma sıcaklığının birçok parametreye bağl1 olmasına karşın genelde 325 $375^{\circ} \mathrm{C}$ aralığında gerçekleştiği kabul edilmektedir (Snee ve diğ. 1988; Knapp ve Heizler 1990). Bu değer, yukarıda tanımlanan dokusal veriler ve kesme ilişkileri ile birlikte değerlendirildiğinde Sarıăgaç biriminin Prekambriyen'de (> 550 My) yüksek sicaklık metamorfizmasına ŭgradı̆̆ $\left(M_{S} 1\right)$, bu kayaların Geç Kretase'de (75-73 My) yeşilşist fasiyesi koşullarında, dinamik ve statik koşullar altında yeniden kristalleştikleri (M2) sonucuna varlmaktadir. Fakat bu düşüncenin, özellikle şistlerden yeni zirkon ve mika yaşlarıyla desteklenmesi gerekmektedir.

Anamur bölgesindeki İnfrakambriyenErken Paleozoik yaşlı birimlerden oluşan Kapıdağ napı'nda gözlenen Barrov tipi yeşilşist fasiyesi metamorfizmasının yaşına ait herhangi bir radyometrik yaş verisi yoktur. Yukarıda tartışıldığ1 gibi bu nap, Alanya bölgesindeki Kapıdağ napı içinde yer alan Kargıcak şist birimi (Çetinkaplan ve diğ., 2016) ile ilksel fasiyes ve metamorfizma türü / derecesi açısından rahatlıkla deneştirilebilmektedir. Kargıcak şist birimindeki Barrov tipi yeşilşist fasiyesi metamorfizması beyaz mikalardaki Ar/Ar yaşlarına dayalı olarak 75 My olarak saptanmıştır (Çetinkaplan ve diğ., 2016). Kapıdağ napını oluşturan tortul kayaların ilksel çökelim yaşları, Anatolid - Toridler'de bugüne kadar Variskan metamorfizmasına ait bir verinin saptanmamış olması ve Alanya'daki Kapıdağ napıyla olan benzerlik göz önüne alındığında, Anamur bölgesinde de Kapıdağ napı olarak tanımlanan kayaç istifini etkileyen Barrov türü yeşilşist fasiyesi metamorfizmasının $\left(\mathrm{M}_{\mathrm{K}} 1\right)$ 
Alpin yaşlı (Geç Kretase ?) olma olasılı̆̆ 1 yüksek olduğu söylenebilir.

\section{SONUÇLAR}

Alanya Masifi'nin güneydoğu ucunda yüzeyleyen metamorfikler, üst amfibolit fasiyesi koşullarında $\left(670 \pm 20^{\circ} \mathrm{C} / 7,7 \pm 0,7\right.$ kbar $)$ metamorfizmaya uğramış, asidik /bazik magmatik kayaçlar tarafından kesilen paraotokton konumdaki Sarıăaç birimi ve bu yüksek dereceli metamorfikleri tektonik bir dokanakla üzerleyen, orta basınç metamorfizmasının yeşilşist fasiyesi koşullarında başkalaşıma uğramış, düzenli ve kalın bir istifle tanımlanan Kapıdağ napından oluşmaktadır. İyi korunmuş ilksel sedimanter özellikler, Kapıdağ napının Toridler'in Geyikdağı ve Antalya birliklerinde gözlenen İnfrakambriyen - Kambro-ordovisiyen serilerden türediğini göstermektedir. Sarıăgaç biriminde yüksek dereceli minerallerin yönelimleriyle tanımlanan bölgesel foliyasyonu kesen aplitik damarların zirkon $\mathrm{U} / \mathrm{Pb}$ yöntemiyle 550 My kristalizasyon yaşı vermeleri, paraotokton temeli oluşturan şistlerin ilksel kırıntılılarının sedimantasyon yaşının Prekambriyen olduğunu göstermektedir. Söz konusu temel Geç Neoproterozoyik’te, olasılıkla Gondwana süper kıtasının bütünleşme süreciyle ilişkili yükssek sıcaklık metamorfizmasına uğramıştır. Beyaz mikalardan elde edilen 75-73 My Ar/Ar soğuma yaşları yüksek dereceli temelin Geç Kretase'de, büyük olasılıkla üzerleyen Kapıdağ nap birimleriyle birlikte yeşil şist fasiyesi koşullarında ikinci bir metamorfizmaya uğradığını göstermektedir. Alanya Masifi'nin geneli ile uyumluluk gösteren bu Geç Kretase metamorfizması Neotetis Okyanusu'nun güney kolunun kuzey yönlü bir yitimle kapanması ve izleyen evrede gerçekleşen kıtasal çarpışma ile ilişkilendirilebilir.

\section{KATKI BELIRTME}

Yazım sürecince yaptığı katkılarla hocam Prof. Dr. Osman Candan'a, zirkon yaş tayini çalışmalarını gerçekleştiren Doç.Dr. O. Ersin Koralay'a, arazi çalışmalarına yaptığı katkılarla Dr. Hüseyin Kozlu'ya, Potsdam Üniversitesi yaş tayini laboratuvarında çalışan Dr. Masafumi Sudo’ya, değerli görüş ve önerileri için Prof. Dr. Musa Alpaslan ve Prof. Dr. Hüseyin Yalçın'a çok teşekkür ederim.

\section{EXTENDED SUMMARY}

Turkey is formed by a number of continental fragments separated by approximately east west direction suture zones in connection with the closure of the Neotethys ocean branchs. This tectonic mosaic developed as a result of successive rifting and oceanic processes along the northern edge of Gondwana. The Taurids and Anatolites, which are metamorphic equivalents of Taurides, are tectonic units of Gondwana origin. In Early Mesozoic, Anatolide and Tauride which have common Palaeozoic - Early Triassic stratigraphy, were taken off from Gondwana as a isolated block by opening the northern and southern branchs of the Neotethys ocean (Göncüoğlu et al., 2003, Okay et al., 1996). Based on the primitive accumulation environment and the sedimentary facies characteristics, the Anatolide - Tauride block is divided into many units from south to north towards Alanya, Antalya, Geyik Mountain, Aladăg and Bozkır. In this structure, it is assumed that the Alanya Massif is derived from the northwarth subduction of the Neotethys ocean in the Late Cretaceous and the associated multistage metamorphism after the Alanya unit.

Alanya Massif is characterized by eclogiteblue schist facies metamorphism and overprinting Barrow-type green schist facies metamorphism (Okay 1989; Bozkaya and Yalçın 2004; Çetinkaplan et al., 2016). On the other hand, in 
the south east of the Masif, Anamur region suffered to high temperature metamorphism represented by sillimanite, kyanite and stavrolite (Işılk and Tekeli, 1995). Main units in Anamur area are from top to bottom; I) The metamorphics belonging to the Alanya Massif are unconformably overlain by ii) Paleocene - Eocene aged Anamur Formation (Ulu, 1989) and iii) Hadim nappe thrusted in Late Eocene - Oligocene (Turan et al., 2007) (Figure lab). The Alanya Massif metamorphics have a simple stratigraphy in the region and are represented by the Sarıağaç unit at the bottom and Kapıdağ nappe on the top with a tectonic contact (Figure 1b). The Sarağaç Unit which is in the paraotokton position is defined by high grade schists that have undergone metamorphism in the upper amphibolite facies. The schists, which are derived from Precambrian aged psamitic-pelitic detritals, are cut by $550 \mathrm{Ma}$ aged, generally acidic aplitepegmatite in composition and more rarely basic magmatic vein rocks. The Kapldağ nappe, which forms a regular and thick sequence, begins with a probable Infra-Cambrian aged assemblage in the base consisting of dolomite, marble, muscovitequartz schist and chlorite schist alternation. This assemblage is overlain with stratigraphic contact by low-grade metamorphics of Tauride units consist of quartzite, meta-carbonate and schists derived from Hüdai, Çaltepe and Seydişehir formations in Cambro-Ordovician aged. All these metamorphic units are unconformably overlain by conglomerates belonging to Late EoceneOligocene Anamur Formation and then Hadim nappe thrusted over to all units.

There are 2 foliations called $S_{S} 1$ and $S_{S} 2$ in the schists of Sarıăgaç unit (Figure 3). $S_{S} 1$ foliation associated with M1 metamorphism is represented by some or all of stavrolite, disthene, garnet and biotite-I ( \pm muscovite-I) minerals. $S_{S} 2$ foliation, which is the product of M2 metamorphism, is defined by chlorite, biotite-II and muscovite-II minerals. There is a foliation called $S_{K} 1$ in the Kapıdag nappe. The $S_{K} 1$ foliation represented by chlorite, muscovite and \pm biotite minerals is the equivalent of the $S_{s} 2$ foliation defining the Barrow type metamorphism which also affected the Sarıăgaç unit.

The metamorphism (M1) conditions of the high grade schists of the Sarıăgaç unit are $7.7 \pm 0.7 \mathrm{kbar}$ and $670 \pm 20^{\circ} \mathrm{C}$. This high-grade assemblage underwent retrogration $5.1 \pm 0.3 \mathrm{kbar}$ and $480 \pm 40^{\circ} \mathrm{C}$ (M2) in conditions. The dating of this metamorphism is 75-73 Ma (Campanian) based on Ar/Ar white mica aging. The age of M1 metamorphism could not be directly determined. Zircon ages of 550.2 $\pm 8.2 \mathrm{Ma} / \mathrm{U}-\mathrm{Pb}$, which is interpreted as the age of crystallization of the primary acidic magmatics and the meta-aplites intersecting the regional foliation which is product of M1 metamorphism suggest that this metamorphism affecting the basement is probably Precambrian aged.

This data also reveals that the primary metaclastic rocks of the basement-forming metamorphic rocks are Precambrian aged. Given the paleogeographic location of the Alanya Massif and geochronological data, the M1 metamorphism may be associated with the integration process of Gondwana's Late Neoproterozoic. This highgrade basement was overprinted by the M2 metamorphism developed from the greenschist facies in the Late Cretaceous, associated with the closure of the southern part of the Neotethys ocean.

\section{ORCID}

Mete Çetinkaplan (D)

https://orcid.org/0000-0002-5802-7690

\section{DEĞIINILEN BELGELER}

Abbo A., Avigad D., Gerdes A. ve Güngör T., 2015. Cadomian basement and Paleozoic to Triassic siliciclastic of the Taurides (Karacahisar dome, South-central Turkey): Paleogeographic 
constraints from U-Pb-Hf in zircons. Lithos, 227, 122-139.

Anderson, J. L. ve Smith, D. R., 1995. The effect of temperature and oxygen fugacity on Al-inhornblende barometry. American Mineralogist, 80, 549-59.

Aoya, M., 2001. P-T-D path of eclogite from the Sambagawa belt deduced from combination of petrological and microstructural analyses. Journal of petrology, 42(7), 1225-1248.

Aoya, M., Uehara, S-ì., Matsumoto, M., Wallis, S.R. ve Enami M., 2003. Subduction stage pressure-temperature path of eclogite from the sabbagawa belt: Prophetic record for oceanicridge subduction. Geological society of America. 31 (12), 1045-1048.

Beyarslan, M., Lin, Y.C., Bingöl, A.F. ve Chung, S.L., 2016. Zircon U-Pb age and geochemical constraints on the origin and tectonic implication of Cadomian (Ediacaran-Early Cambrian) magmatism in SE Turkey. Journal of Asian earth Sciences, 130, 223-238.

Bourdelle, F., Parra, T., Chopin, C. ve Beyssac, O., 2013. A new chlorite geothermometer for diagenetic to low-grade metamorphic conditions. Contribution Mineralogy and Petrology, 165:723-735

Bozkaya, Ö., 1999. Alanya Metamorfitleri doğu kesiminin (Anamur kuzeyi) mineralojisi: Kristalinite, $\mathrm{b}_{0}$ ve politipi. 11. Mühendislik Haftas1 Yerbilimleri Sempozyumu Bildiriler Kitabı, Isparta.

Bozkaya, Ö., 2001. Demirtaş-Alanya yöresinde Alanya naplarının metamorfizmasına ilişkin yeni mineralojik bulgular, Orta Toroslar, Türkiye. Yerbilimleri, 23, 71-86.

Bozkaya, Ö. ve Yalçın, H., 2004. New Mineralogic Data and Implications for the Tectonometamorphic Evolution of the Alanya Nappes, Central Tauride Belt, Turkey. International Geology Review, 46:4, 347-365

Bozkaya, Ö., Gürsu, S. ve Göncüoğlu, M.C., 2006. Textural and mineralogical evidence for a Cadomian tectonothermal event in the eastern Mediterranean (Sandikl1-Afyon area, western Taurides, Turkey). Gondwana Research 10, 301315.

Bozkurt, E. ve Satır, M., 2000. The southern Menderes Massif (western Turkey): geochronology and exhumation history. Geology, 35, 285-296.
Candan, O., Çetinkaplan., M., Oberhansli, R., Rimmele, G. ve Akal, C., 2005. Alpine high-pressure / Low temperature metamorphism of Afyon Zone and implication for metamorphic evolution of western Anatolia, Turkey. Lithos, 84, 102-124.

Candan, O., Koralay, O. E., Akal, C., Kaya, O., Oberhänsli, R., Dora, O. Ö. ve Chen, F., 2011a. Supra-Pan-African unconformity between core and cover series of the Menderes Massif/Turkey and its geological implications. Precambrian Research, 184, 1-23.

Candan, O., Dora, O.Ö., Oberhänsli, R., Koralay, O.E., Çetinkaplan, M., Akal, C., Satır, M., Chen, F. ve Kaya, O., 2011b. Stratigraphy of the PanAfrican Basement of the Menderes Massif and the relationship with late Neoproterozoic/Cambrian evolution of the Gondwana. Bulletin of the Mineral Research and Exploration 142, 25-69.

Candan, O., Oberhänsli, R., Dora, O. Ö., Çetinkaplan, M., Koralay, O. E., Rimmele, G. ve Akal, C. (2011c). Polymetamorphic evolution of the PanAfrican Basement and Palaeozoic - Early tertiary cover series of the Menderes Massif. Bulletin of the Mineral Research and Exploration, 142, 121165.

Candan O., Koralay O.E., Topuz, G., Oberhansli R., Fritz, H, Collins A.S. ve Chen F., 2016. Late Neoproterozoic gabbro emplacements followed by early Cambrian eclogite-facies metamorphism in the Menderes Massif (W. Turkey): Implications on the final assembly of Gondwana. Gondwana Research, 34, 158-173.

de Capitani, C. ve Brown, T.H., 1987. The computation of chemical equilibrium in complex systems containing non-ideal solutions. Geochim Cosmochim Acta, 51, 2639-2652.

de Capitani, C. ve Petrakakis, K., 2010. The computation of equilibrium assemblage diagrams with Theriak/ Domino software. American Mineralogist, 95, 1006-1016

Carswell, D.A., 1990. Eclogites and the eclogite facies: definitions and classifications. Eclogite facies rocks. Glasgow: Blackie, 1-3.

Catlos, E.J. ve Çemen, I., 2005. Monazite ages and the evolution of the Menderes Massif, western Turkey. International Journal of Earth Science,94, 204-217.

Collins, A. S., 2006. Madagascar and the amalgamation of Central Gondwana. Gondwana Research, 9, 3-16. 
Compagnoni, R. ve Maffeo, B., 1973. Jadeite-bearing metagranites 1.s. and related rocks in Mount Mucrone area (Sesia-Lanzo Zone, Western Italian Alps). Schweizerische-Mineralogische-undPetrographische-Mitteilungen, 53, 355-78.

Çetinkaplan, M., Pourteau, A., Candan, O., Koralay, O. E., Oberhänsli, R., Okay, A.I., Chen, F., Kozlu, H. ve Şengün, F., 2016. P-T-t evolution of eclogite/blueschist facies metamorphism in Alanya Massif: time and space relations with HP events in Bitlis Massif, Turkey. International journal of Earth Science, 105(1), 247-281.

Dean, W.T., 2005. Trilobites from Çal tepe Formation (Cambrian), near Seydişehir, Central Taurides, Southwestern Turkey: Turkish Journal of Earth Sciences, 14,1-71.

Dean, W.T., 2006. Cambrian stratigraphy and trilobites of the Samur Dağ area, south of Hakkâri, southeasternTurkey. Turkish Journal of Earth Sciences 15, 225-257.

Dean, W.T. \& Monod, O., 1970. The Lower Palaeozoic stratigraphy and faunas of the Taurus Mountains near Beyflehir, Turkey. I. Stratigraphy. Bulletin of the British Museum (Natural History), Geology 19, 413-426.

Dean WT, Özgül N., 1994. Cambrian rocks and faunas, Hüdai area, Taurus Mountains, southwestern Turkey. Bull Inst Roy Sci Nat Belg 64: 5-20.

Dean W.T., Uyeno, T.T. ve Rickards R.B., 1999. Ordovician and Silurian stratigraphy and trilobites, Taurus Mountains near Kemer, southwestern Turkey. Geological Magazine 136(4),373-393.

Demirkol, C., 1988. "Türkoğlu (Kahramanmaraş) batısında yer alan Amanos Dağlarının stratigrafisi, yapısal özellikleri ve tektonik evrimi", Maden Tetkik ve Arama Enstitüsü Dergisi, 108, 18-37.

Erdoğan, B. ve Dora, Ö., 1983. Bitlis Masifi apatitli demir yataklarının jeolojisi ve oluşumu: Türkiye Jeoloji Kurumu Bülteni, 26, 133-144.

Erdoğan, B., Uchman, A., Güngör, T. ve Özgül, N., 2004. Lithostratigraphy of the Lower CambrIan metaclastics and their age based on trace fossils in the Sandikli region, southwestern Turkey. Geobios, 38, 346-60.

Forbes, R. B., Evans, B. W. ve Thurston, S. P., 1984. Regional progressive high-pressure metamorphism, Seward Peninsula. Alaska. Journal of Metamorphic Geology, 2, 43-54.
Fox, J. S., 1975. Three dimensional isograds from the Lukmanier Pass, Switzerland, and their tectonic significance. Geological Magazine, 112, 547-564.

Fritz, H., Abdelsalam, M., Ali, K. A., Bingen, B., Collins, A.S., Fowler, A. R. ve Viola, G., 2013. Orogen styles in the East African Orogen: A review of the Neoproterozoic to Cambrian tectonic evolution. Journal of African Earth Sciences, 86, 65-106.

Ghienne, J.F., Monod, O., Kozlu, H. ve Dean, W.T., 2010. Cambrian-Ordovician depositional sequences in the Middle East: A perspective from Turkey. Earth-Science Rewiews, doi:10.1016/j. earscirev.2010.04.004.

Göncüoğlu, M.C., Göncüoğlu, Y., Kozlu, H. ve Kozur, H., 2004. Geological evolution of the Taurides during the Infra-Cambrian to Carboniferous period: a Gondwanan perspective based on new biostratigraphic findings. Geol Carphatica, 55/6, 433-447.

Göncüoğlu M.C. ve Kozlu, H., 2000. Early Paleozoic evolution of NW Gondwanaland: data from southern Turkey and surrounding regions. Gondwana Research, 3, 315-323.

Göncüoglu, M.C. ve Turhan, N., 1997. Rock units and metamorphism of the basement and Lower Paleozoic cover of the Bitlis Metamorphic Complex, SE Turkey: in: Göncüoglu, M.C.and Derman, A.S.(Eds), Lower Paleozoic Evolution in northwest Gondwana, Turkish Association of Petroleum Geologists, Special. Publication,3, 7581, Ankara

Göncüoğlu, M.C., Turhan, N. ve Tekin, U.K., 2003, Evidence for the Triassic rifting and opening of the Neotethyan Izmir-Ankara Ocean, northern edge of the Tauride-Anatolide Platform, Turkey. Bollettino della Società Geologica Italiana Special, 2, 203 212.

Graham, C.M ve Powell, R., 1984. A garnethornblende geothermometer: calibration testing and application to the Pelona schist, Southern California. Journal of Metamorphic Geol ogy, 2, 13-31

Güngör, T., 2013. Kinematics of the Central Taurides during Neotethys closure and collision, the nappes in the Sultan Mountains, Turkey. International Journal of Earth Sciences 102 (5), 1381-1402

Gürsu, S. ve Göncüoglu, M.C., 2005. Batı torosların (sandıklı GB'sı, Afyon) Geç Neoproterozoiyik 
ve Erken paleozoyik yaşlı birimlerin jeolojisi ve petrografisi. Maden Tetkik Arama dergisi, 130, 29-55.

Gürsu, S. Göncüoglu, M.C. ve Bayhan, H., 2004. Geology and geochemistry of the preEarly Cambrian rocks in the Sandiklı area: implications for the Pan-African evolution in NW Gondwanaland Gondwana Research, 7, 923-935

Gürsu, S., Kozlu, H., Göncüoğlu, M.C. ve Turhan, N., 2003. Orta Torosların batı kesimindeki temel kayaları ve Alt Paleozoyik örtülerinin korelasyonu. Türkiye Petrol Jeologları Derneği Bülteni, 15, 129-153.

Gürsu, S., Möller, A., Göncüoglu, MC., Köksal, S., Demircan, H., Toksoy Köksal, F., Kozlu, H. ve Sunal, G., 2015. Neoproterozoic continental arc volcanism at the northern edge of the Arabian Plate, SE Turkey. Precambrian Research, 258, 208-233.

Hammarstrom, J.M. ve Zen, E., 1986. Aluminum in hornblende: an empirical igneous geobarometer. American Mineralogist, 71, 1297-1313

Harlow, G. E., 1994. Jadeitites, albitites and related rocks from the Matagua Fault Zone, Guatemala. J. Metam. Geol., 12, 49-68.

Heinrich A.C., 1982. Kyanite-eclogite to amphibolite facies evolution of hydrous mafic and pelitic rocks, Adula nappe, central Alps. Contribution Mineralogy and Petrology, 81, 30-38.

Henry, D.J., Guidotti, C.V. ve Thomson, J.A., 2005. The Ti-saturation surface for low-to-medium pressure metapelitic biotites: Implications for geothermometry and Ti-substitution mechanisms. American Mineralogist, 90, 316-328.

Hetzel, R. ve Reischmann, T., 1996. Intrusion age of PanAfrican augen gneisses in the southern Menderes Massif and the age of cooling after Alpine ductile extensional deformation. Geological Magazine, 133, 565-572.

Hetzel, R., Romer, R., Candan, O. ve Passchier, C.W., 1998. Geology of the Bozdad area, central Menderes Massif, SW Turkey: Pan - African basement and Alpine deformation. Geologische Rundschau, 87, 394-406.

Holdaway, M. J., 2000. Application of new experimental and garnet Margules data to the garnet-biotite geothermometer. American Mineralogist 85, 881892
Hoschek, G., 1969. The stability of stavrolite and chloritoid and their significance in metamorphism of pelitic rocks. Contribution Mineralogy and Petrology. 22, 208-232.

Işık, V. ve Tekeli, O., 1995. Alanya metemorfiklerinin doğu kesiminde yer alan petrografik bulgular. Maden Tetkik Arama Dergisi, 117, 105-113

Johnson, P. R., Andresen, A., Collins, A. S., Fowler, A. R., Fritz, H., Ghebreab, W. Ve Stern, R. J., 2011. Late Cryogenian-Ediacaran history of the Arabian-Nubian Shield: A review of depositional, plutonic, structural, and tectonic events in the closing stages of the northern East African Orogen. Journal of African Earth Sciences, 61, 167-232.

Ketin, I., 1966. Anadolu'nun tektonik birlikleri. Maden Tetkik Arama Dergisi, 66, 20-34 (Ankara)

Kleemann, U. ve Reinhardt, J., 1994. Garnet-biotite thermometry revisited: the effect of $\mathrm{Al}^{\mathrm{vi}}$ and $\mathrm{Ti}$ in biotite. European Journal of Mineralogy 6, 925941.

Knapp, J. H. ve Heizler M. T., 1990. Thermal history of crystalline nappes of the Maria fold and thrust belt, West Central Arizona. Journal of Geophysical Research 95, 20049-20073.

Kohn, M.J. ve Spear, F.S., 1989. Empirical calibration of geobarometers for the assemblage garnet + hornblende + plagioclase + quartz. American Mineralogist, 74, 77-84.

Koralay, O.E., 2015. Late Neoproterozoic granulite facies metamorphism in the Menderes Massif, western Anatolia/Turkey: Implication for the assembly of Gondwana. Geodinamica Acta, 27 (4), 244-266.

Koralay, O.E., Candan, O., Akal, C., Dora, O.Ö., Chen, F., Satır, M. ve Oberhänsli, R., 2011. Geology and geochronology of the Pan-African and Triassic metagranitoids in the Menderes Massif, Western Anatolia, Turkey. Bulletin of the Mineral Research and Exploration 142, 69-121.

Kozlu, H., 1990. Tufanbeyli - Sarız - Gürün dolayının jeolojisi ve hidrokarbon olanakları. T.P.A.O. Rep. No:2851, 138s.

Kozlu, H. ve Göncüoğlu, M.C., 1997. Stratigraphy of the Infra-Cambrian rock-units in the Eastern Taurides and their correlation with similar units in southern Anatolia. In: Göncüoğlu, M.C., Derman, A.S. (Eds.), Early Palaeozoic Evolution in NW Gondwana: Turkish Association of Petroleum Geologists, Special Publication, 3, 50-60. 
Kozlu, H., Göncüoğlu, M.C., Sarmiento, G. ve Gül, M.A., 2002. Mid-Ordovician (Late Darriwilian) conodonts from the Southern-Central Taurides, Turkey: geological implications. Turkish Journal of Earth Sciences 11, 113-126.

Krogh Ravna, E., 2000. The garnet-clinopyroxene $\mathrm{Fe}-\mathrm{Mg}$ geothermometer: an updated calibration. Journal of Metamorphic Geology, 18, 211-219

Kroner, A. ve Şengör, A. M. C., 1990. Archean and Proterozoic ancestry in late Precambrian to ealy Paleozoic crustal elements of southern Turkey as revealed by single-zircon dating. Geology, 18(11), $86-90$

Kryza, R., Muszynski, A. ve Vielzeuf, D., 1990. Glaucophane-bearing assemblage overprinted by greenschist facies metamorphism inthe variscan Kaczawa complex, Sudetes, Poland. Journal of Metamorphic Geology, 8, 345-355.

Lang, H.M. ve Gilotti, J.A., 2001. Plagioclase replacement textures in partially eclogitised gabbros from the Sanddal mafic-ultramafic complex, Greenland Celadonites. Journal of Metamorphic Geology. 19, 497-517.

Leake, BA., Woolley, AR., Birch, W.D., Gilbert, M.C., Grice, J.D., Hawthorne, F.C., Kato, A., Kisch, H.J., Krivovichev, V.G., Linthout, K., Laird, J., Mandarino, J., Maresch, W.V., Nickel, E.H., Rock, N.M.S., Schumacher, J.C., Smith, D.C., Stephonson, N.C.N., Ungaretti, L., Whittaker, E.J.W. ve Youzmi, G., 1997. Nomenclature of amphiboles. Report of the Subcommittee on Amphiboles of the International Mineralogical Association Commission on New Minerals andMineral Names. Eurepean Journal of Mineralogy, 9, 623-651.

Loos, S. ve Reischmann, T., 1999. The evolution of the southern Menderes Massif in SW Turkey as revealed by zircon dating. Journal of the Geological Society, 156, 1021-1030.

Maruyama, S., Cho, M.veLiou,J.G., 1986. Experimental investigation of blueschist-greenschist transition equilibria: pressure dependence of $\mathrm{Al} 203$ contents in sodic amphiboles - A new geobarometer. Geological Society of America Memoir 164, Blueschist and Eclogites, 1, 1-16.

Masonne, H.J., 2012. Formation of Amphibole and Clinozoisite-Epidote in Eclogite owing to Fluid Infiltration during Exhumation in a Subduction Channel. Journal of Petrology, 53(10), 1969-1998.
Massonne, H.J. ve Schreyer, W., 1989. Stability fied of high-pressuri assemblage talc + phengite and two new phengite barometers. Eurepean Journal of Mineralogy, 1, 391-410.

Mclellan, E., 1985. Metamorphic reactions in the Kyanite and Sillimanite zones of Barrovian type area. Journal of Petrology, Vol 26, part 4, pp. 789818.

McDougall, I. ve Harrison, T.M., 1999. Geochronology and Thermochronology by the ${ }^{40} \mathrm{Ar} /{ }^{39} \mathrm{Ar}$ Method. Oxford University Press, New York.324s.

Meinhold, G., 2010. Rutile and its applications in earth sciences. Earth science rewiews, 102, 1-28.

Monod, O., 1977. Recherches geologiques dans le Taurus occidental ausud de Beyşehir (Turquie) These de l'Universite de Paris-Sud (Orsay), $442 \mathrm{p}$.

Monod, O., Kozlu, H., Ghienne, J.F., Dean, W.T., Günay, Y., Le, Herisse, A., Paris, F. ve Robardet, M., 2003. Late Ordovician glaciation in southern Turkey.Terra Nova, 15, 249-257.

Möller C., 1998. Decompressed eclogites in the Sveconorwegian (Grenvillian) orogen of SW Sweden: petrography and tectonic implications. Journal of Metamorphic Geology, 16, 641-656.

Newton, R.C. ve Haselton, H.T., 1981. Thermodynamics of the garnetplagioclaseAlrSiOr-quartz geobarometer. In $\mathrm{R} \mathrm{C}$ Newton, A Navrotsky, and B.J Wood, Eds, Advances in physical geochemistry, say1 1, s 131-147 SpringerVerlag, New York

Okay A.I.,1989. An exotic eclogite/blueschist slice in a Barrovianstyle metamorphic terrain, Alanya Nappes, Southern Turkey. Journal of Petrology, 30(1), 107-132

Okay, A.I., 1997. Jadeite-K-feldspar rocks and jadeitites from northwest Turkey. Mineralogical Magazine, 61, 835-843.

Okay, A.I., 2002. Jadeite-chloritoid-glaucophanelawsonite schists from northwest Turkey: unusually high $\mathrm{P} / \mathrm{T}$ ratios in continental crust. Journal of Metamorphic Geology, 20, 757-768.

Okay, A.I. ve Özgül, N., 1984. HP/LT metamorphism and structure of the Alanya Massif, Southern Turkey: an allochthonous composite tectonic sheet. In: Robertson AHF, Dixon TE (ed) The geological evolution of the Eastern Mediterranean. Geological Society London Special Publication, 14, 429-439. 
Okay, A.I. ve Tüysüz, O., 1999. Tethyan sutures of northern Turkey. In: Durand B, Jolivet L, Horváth F, Séranne M (eds) The Mediterranean Basins: Tertiary extension within the Alpine orogen. Geological Society London Special Publication, 156, 475-515.

Okay, A.I, Satır, M., Maluski, H., Siyako, M., Monie, P., Metzger, R. ve Akyuz, S., 1996. Paleo- and NeoTethyan events in northwest Turkey: geological and geochronological constraints. In: Yin A, Harrison M (eds) Tectonics of Asia. Cambridge University Press, Cambridge, 520s.

Okay, A.I, Satır, M. ve Siebel, W., 2006. Pre-alpide orogenic events in the Eastern Mediterranean region. European lithosphere dynamics. Geological Society London Memoirs 32, 389405.

Okay, A., Tansel, I. ve Tüysüz, O., 2001. Obduction, subduction and collusion as reflected in the Upper Cretaceous-Lover Eocene sedimentary record of western Turkey. Geological Magazine, 138 (2), $117-142$.

Özgül, N., 1976. Toroslar'ın bazı temel jeoloji özellikleri. Türkiye Jeoloji Kurumu Bülteni 19, 65-78.

Özgül, N., 1984. Stratigraphy and tectonic evolution of the Central Taurides. International symposium on the geology of the Taurus Belt. Tekeli O, Göncüoğlu M.C. (ed), Ankara-Turkey, 77-90.

Özgül, N., 1997. Bozkır-Hadim-Taşkent (Orta Toroslar'ın Kuzey Kesimi) Dolaylarında Yer Alan Tektono - Stratigrafik Birliklerin Stratigrafisi. Maden Tetkik Arama Enstitüsü Dergisi, 119, 117174.

Özgül, N. ve Gedik, İ., 1973. Orta Toroslar- da Alt Paleozoyik yagta Çaltepe Kireç- taşı ve Seydişehir Formasyonu'nun stratigrafisi ve konodont faunasi hakkında yeni bilgiler. Türkiye Jeoloji Kurumu Bülteni, 16(2), 39-52.

Özgül, N. ve Kozlu, H., 1992. Kozan-Feke-Mansurlu arasının jeolojisi. T.P.A.O. Rep. No:3380, 127s.

Özgül, N. ve Kozlu, H., 2002. Kozan-Feke (Doğu Toroslar) Yöresinin Stratigrafisi ve Yapisal Konumu ile İlgili Bulgular. Türkiye Petrol Jeologları Derneği Bülteni, 14(1),1-36.

Özgül, N., Metin, S. ve Dean, W. T., 1972. Doğu Toroslar'da Tufanbeyli ilçesi (Adana) dolayının Alt Paleozoyik stratigrafisi ve faunasi; Maden Tetkik Arama Enstitüsü Dergisi, 79, 9-17.
Parlak, O., Rizaoglu, T., Bagcı, U., Karaoglan, F. ve Höck, V., 2009. Tectonic significance of the geochemistry and petrology of ophiolites in southeast Anatolia, Turkey. Tectonophysics 473, 173-187.

Patrick, B. E. ve Evans, B. W., 1989. Metamorphic evolution of the Seward Peninsula blueschist terrane. Journal of Petrology, 30, 531-555.

Perchuk, L.L., 2004. Progress in Metamorphic and Magmatic Petrology: A Memorial Volume in Honour of D.S. Korzhinskiy. Ed. L.L. Perchuk. Cambridge University Press, 520 p.

Pognante, U., 1985. Coronitic reactions and ductile shear zones in eclogitized ophiolite metagabbro, western Alps, north Italy. Chemical Geology, 50, 99-109.

Pourteau, A., Sudo, O., Candan, O., Lanari, P., Vidal, O. ve Oberhansli, R., 2013, Neotethys closure history of Anatolia: insights from ${ }^{40} \mathrm{Ar}-{ }^{39} \mathrm{Ar}$ geochronology and $\mathrm{P}-\mathrm{T}$ estimation in highpressure metasedimentary rocks. Journal of Metamorphic Geology. 31(6), 585-606.

Proyer, A., 2003. The preservation of high-pressure rocks during exhumation: metagranites and metapelites. Lithos 70, 183-194.

Rubie, D.C., 1986. The catalysis of mineral reactions by water and restrictions onthe presence of aqueous fluid during metamorphism. Mineralogical Magazine, 50, 399-415.

Rolland, Y., Billo, S., Corsini, M., Sosson, M. ve Galoyan, G., 2009. Blueschists of the AmassiaStepanavan Suture Zone (Armenia): linking Tethys subduction history from E-Turkey to W-Iran. International Journal of Earth Science 98, $533-550$

Satır, M., Friedrichsen, H., 1986. The origin and evolution of the Menderes Massif, W Turkey: a rubidium/strontium and oxygen isotope study. Geologische Rundschau.75, 703-714.

Schmidt, M. W., 1992. Amphibole composition in tonalite as a function of pressure: an experimental calibration of the Al-in-hornblende barometer. Contribution Mineralogy and Petrography,110, 304-310.

Schmidt, A., Pourteau, A., Candan O. ve Oberhansli R., 2015. Lu-Hf geochronology on cm-sized garnets using microsampling: New constraints on garnet growth rates and duration of metamorphism 
during continental collision (Menderes Massif, Turkey). Earth and Planetary Science Letters, 432, 24-35.

Sisson, V. B., Ertan, I. E. ve ave Lallemant, H. G., 1997. High pressure (2000 MPa) kyanite- and glaucophane-bearing pelitic schist and eclogite from Cordillera de la Costa Belt,Venezuela. Journal of Petrology, 38, 65-83.

Snee, L.W., Sutter, J.F. ve Kelly, W.C., 1988. Thermochronology of economic mineral deposits-Dating the stages of mineralization at Panasqueira, Portugal, by high-precision 40Ar/39Ar age-spectrum techniques on muscovite: Economic Geology, 83, 335-354.

Spear, F.S., 1993. Metamorphic Phase Equilibria and Pressure-Temperature-Time Paths. Mineralogical Society of America, Washington, D.C., 799pp

Şenel, M., Gedik, I., Dalkılıç, N., Serdaroğlu, M., Bilgin. A.Z,. Uğuz, M.F., Bölükbaş1. A.S., Korucu, M. ve Özgül, N., 1996. Isparta büklümü doğusunda otokton ve allokton birimlerin stratigrafisi (Batı Toroslar). Maden Tetkik Arama Enstitüsü Dergisi, $118,111-160$.

Şengor, A.M.C., Görür, N. S. ve Karoğlu, F., 1985. Strike-slip faulting and related basin formation in zones of tectonic escape: Turkey as a case study. In: Biddle KT, Christie-Blick N (eds), Strike-slip deformation, Basin formation and sedimentation. Society Economic Mineral Paleontology and Mineralogy Special Publication, 37, 227-264

Şengör, A.M.C. ve Yılmaz,Y. 1981. Tethyan evolution of Turkey: a plate tectonic approach. Tectonophysics, 75,181-241.

Şengör, A.M.C., Yılmaz, Y. ve Ketin, I., 1980 Remnants of a pre-Late Jurassic ocean in the northern Turkey: fragments of Permian-Triassic PaleoTethys. Geological Society American Bulletin, 91(1), 599-609.

Şengör, A.M.C., Yilmaz, Y. Ve Sungurlu, O., 1984. Tectonics of the Mediterranean Cimmerides: nature and evolution of the western termination of Palaeo-Tethys. The Geological Evolution of the Eastern Mediterranean. In: Dixon, J.E., Robertson, A.H.F.(Eds.)., Geological Society, London, Special Publications 17, 77-112.
Tsujimori T., 2010. Prograde and terrograde P-T paths of the late paleozoic glaucophane eclogite from the Renge metamorphic belt, Hida Mountains, Southwestern Japan. International Geology Rewiew, 44(9), 797-818.

Tsujimori, T. ve Ernst W.G., 2014. Lawsonite blueshist and lawsonite eclogites as proxies for paleosubduction zone processes: a review. Journal of Metamorphic Geology,32(5), 437-454.

Tsujimori, T. ve Liou, J.G., 2007. Significance of the Ca-Na pyroxene-lawsonite-chlorite assemblage in blueschist-facies metabasalts: An example from the Renge metamorphic rocks, southwest Japan. International Geology Review 49 (5), 416-430

Tuccillo, M.E., Essene, E.J. ve van der Pluijm, B.A., 1990. Growth and retrograde zoning in garnets from high-grade metapelites: implications for pressure-temperature paths. Geology, 18, 839843.

Turan, A., 2000. Korualan Bağbaşı (Hadim-Konya) arasındaki bölgenin yapısal özellikleri; Dokuz Eylül Üniversitesi Fen ve Mühendislik Dergisi, 2(3), 51-60.

Turan, A., Kurtman, F. ve Seymen, İ., 2007 Toroslarda Hadim bölgesinin paleotektonik dömen jeolojik evrimi. Selçuk Üniversitesi Mühendislik Mimarlık Fakültesi Dergisi, 23,1-2.

Ulu, Ü., 1989. Gazipaşa (Antalya ili) bölgesinin jeolojisi Doktota Tezi, İ.Ü. Fen Bilimleri Enst., 209s (Yayınlanmamış).

Ustaömer, P.A., Ustaömer, T., Collins, A.S. ve Robertson, A.H.F., 2009. Cadomian (EdiacaranCambrian) arc magmatism in the Bitlis Massif, SE Turkey: magmatism along the developing northern margin of Gondwana. Tectonophysics 473, 99-112.

Yalçın, N., 1980. Amanosların Litolojik Karakterleri ve GüneydoğuAnadolu'nun Tektonik Evrimindeki Anlamı. Türkiye Jeoloji Kurumu, 23,21-30

Yılmaz, Y., 1993. New evidence and model on the evolution of the southeast Anatolian orogen. Bulletin Geological Society of America, 105, 252-271. 